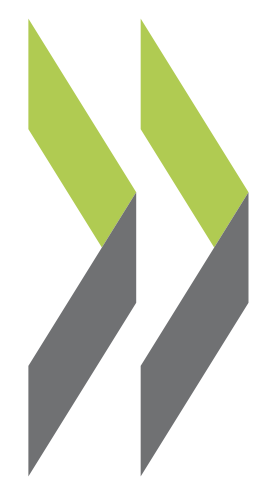

OECD Economics Department Working Papers No. 1170

\section{A Revival of the Private Rental Sector} of the Housing Market? Lessons from Germany, Finland, the Czech Republic and the Netherlands
Rik de Boer, Rosamaria Bitetti 
Organisation de Coopération et de Développement Économiques

Organisation for Economic Co-operation and Development

23-Oct-2014

ECONOMICS DEPARTMENT

English - Or. English

\section{A REVIVAL OF THE PRIVATE RENTAL SECTOR OF THE HOUSING MARKET? LESSONS FROM GERMANY, FINLAND, THE CZECH REPUBLIC AND THE NETHERLANDS}

ECONOMICS DEPARTMENT WORKING PAPERS No. 1170

\section{By Rik De Boer and Rosamaria Bitetti}

OECD Working Papers should not be reported as representing the official views of the OECD or of its member countries. The opinions expressed and arguments employed are those of the author(s).

Authorised for publication by Robert Ford, Deputy Director, Country Studies Branch, Economics Department.

All Economics Department Working Papers are available through OECD's Internet website at http://www.oecd.org/eco/Workingpapers

JT03364653

Complete document available on OLIS in its original format

This document and any map included herein are without prejudice to the status of or sovereignty over any territory, to the delimitation of international frontiers and boundaries and to the name of any territory, city or area. 
OECD Working Papers should not be reported as representing the official views of the OECD or of its member countries. The opinions expressed and arguments employed are those of the author(s).

Working Papers describe preliminary results or research in progress by the author(s) and are published to stimulate discussion on a broad range of issues on which the OECD works.

Comments on Working Papers are welcomed, and may be sent to the Economics Department, OECD, 2 rue André-Pascal, 75775 Paris Cedex 16, France, or by e-mail to eco.contact@oecd.org

This document and any map included herein are without prejudice to the status of or sovereignty over any territory, to the delimitation of international frontiers and boundaries and to the name of any territory, city or area.

The statistical data for Israel are supplied by and under the responsibility of the relevant Israeli authorities. The use of such data by the OECD is without prejudice to the status of the Golan Heights, East Jerusalem and Israeli settlements in the West Bank under the terms of international law.

\section{(C) OECD (2014)}

You can copy, download or print OECD content for your own use, and you can include excerpts from OECD publications, databases and multimedia products in your own documents, presentations, blogs, websites and teaching materials, provided that suitable acknowledgment of OECD as source and copyright owner is given. All requests for commercial use and translation rights should be submitted to rights@oecd.org 
ECO/WKP(2014)66

\section{ABSTRACT/RESUMÉ}

\section{A REVIVAL OF THE PRIVATE RENTAL SECTOR OF THE HOUSING MARKET? LESSONS FROM GERMANY, FINLAND, THE CZECH REPUBLIC AND THE NETHERLANDS}

This Working Paper studies ways to stimulate the private rental sector (PRS) of the housing market - and compares experiences with policies and reforms in Germany, the Netherlands, Finland and the Czech Republic. Although in many countries the PRS has decreased in importance since the Second World War, there are signs of a growing importance and possible 'revival' of the PRS. A well-functioning PRS and neutrality in housing policies can improve the functioning of the housing market - by promoting residential mobility, increasing housing options for households and generating competitive supply and affordable prices. The PRS can have positive effects on the economy and labour mobility and reduce inefficiencies and risks of owner-occupied and social housing. Trade-offs between goals in housing policies, and regulatory impediments to a level playing field between segments of the housing market (owner-occupancy, social rental, private rental) are analysed. The article outlines policy options in promoting a wellfunctioning PRS: lessons are drawn on tenancy security, rent-setting regulations, social housing, demand subsidies, fiscal measures for rental and owner-occupied housing and barriers for PRS supply. Experiences from the countries show that it is hard to create a level playing field - there are inefficiencies in all four countries. Nonetheless, there are many positive experiences of stimulating the PRS: reforms in Finland and the Czech Republic stimulated the PRS to become a competitive and important part of the housing market, and Dutch policies are adapted to stimulate a level playing field. The 'resilience' of the German housing system during the economic crisis shows that the large PRS and tenure neutrality have important stabilising effects on the German economy.

JEL Classification: E21; G21; H24; L74; R21; R31; R38; R52.

Key words: Housing market, housing policies, labour mobility, private rental, social rental, house prices, housing finance, Finland, Germany, the Czech Republic, the Netherlands.

\section{RELANCER LE SECTEUR LOCATIF PRIVÉ DU MARCHÉ DU LOGEMENT ? LEÇONS TIRÉES DES EXPÉRIENCES ALLEMANDE, FINLANDAISE, TCHÈQUE ET NÉERLANDAISE}

Nous étudions dans ce Document de travail les mesures pouvant être prises pour stimuler le secteur locatif privé du marché du logement, et comparons les données d'expérience relatives aux politiques publiques et aux réformes mises en œuvre en Allemagne, aux Pays-Bas, en Finlande et en République tchèque. Bien que l'importance du secteur locatif privé ait diminué dans de nombreux pays depuis la Seconde Guerre mondiale, certains signes montrent qu'il reprend de l'importance et qu'il est possible de le «relancer». Un secteur locatif privé fonctionnant bien et des politiques du logement neutres peuvent améliorer le fonctionnement du marché de l'immobilier d'habitation - en favorisant la mobilité résidentielle, en élargissant l'éventail des possibilités de logement offertes aux ménages, et en débouchant sur une offre concurrentielle et des prix abordables. Le secteur locatif privé peut avoir des effets positifs sur l'économie et la mobilité des travailleurs, et réduire les problèmes d'inefficience et les risques inhérents aux logements occupés par leurs propriétaires et au logement social. Les arbitrages à opérer entre les différents objectifs des politiques du logement, et les obstacles réglementaires à l'application de règles du jeu équitables entre les différents segments du marché de l'immobilier d'habitation (logements occupés par leurs propriétaires, logement locatif social, logement locatif privé) sont analysés. L'article expose les options envisageables pour favoriser le bon fonctionnement du secteur locatif privé : des leçons sont tirées concernant la sécurité d'occupation, les règles de fixation des loyers, le logement social, les mécanismes de subventionnement de la demande, les mesures budgétaires en faveur du logement locatif et des propriétaires occupants, ainsi que les obstacles qui limitent l'offre sur le secteur locatif privé. L'expérience des pays considérés montre qu'il est difficile de mettre en place des règles du jeu équitables, puisqu'on observe des problèmes d'inefficience dans chacun des quatre pays examinés. Néanmoins, on relève de nombreux exemples positifs de stimulation du secteur locatif privé : les réformes mises en œuvre en Finlande et en République tchèque ont permis au secteur locatif privé de devenir un segment concurrentiel et important du marché du logement, tandis que les politiques appliquées aux Pays-Bas sont adaptées pour égaliser les conditions de concurrence. La « résilience » dont a fait preuve le système allemand en matière de logement pendant la crise économique montre que l'ampleur du secteur locatif privé et la neutralité de l'action publique vis-à-vis du mode d'occupation des logements ont d'importants effets stabilisants sur l'économie allemande.

Mots-clés : marché du logement, politiques du logement, mobilité de la main-d'œuvre, logement locatif privé, logement locatif social, prix des logements, financement du logement, Finlande, Allemagne, République tchèque, Pays-Bas.

Classification JEL : E21; G21; H24; L74; R21; R31; R38; R52 


\section{TABLE OF CONTENTS}

A Revival of the Private Rental Sector of the Housing Market? Lessons from Germany, Finland, the Czech Republic and The Netherlands

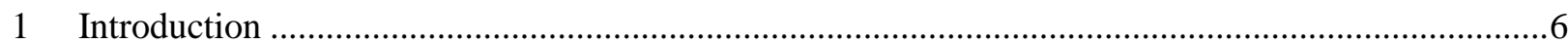

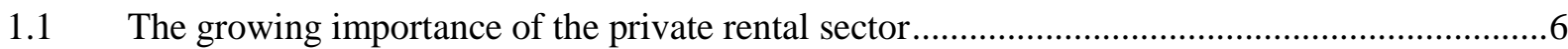

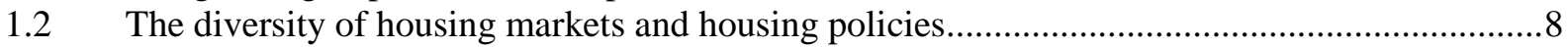

1.3 A level playing field for the PRS: policies, barriers and trade-offs.......................................10

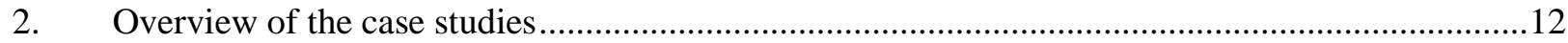

2.1 Germany: a stable housing market with a well-functioning PRS ........................................15

2.3 Finland: a positive experience of housing market deregulation ...............................................15

2.4 Czech Republic: experiences from a housing market in transition ..........................................16

2.5 The Netherlands: a highly regulated housing market with a marginal PRS ...........................17

3. Tenancy security and eviction procedures...............................................................................18

3.1 Adequate tenancy security has positive consequences for the housing market..........................20

3.2 Substantially reducing tenancy security affects long-term demand .........................................20

3.3 Unbalanced tenancy protection and inefficient eviction procedures hamper PRS ....................21

3.4 Findings: the fundamental importance of tenancy security ...................................................22

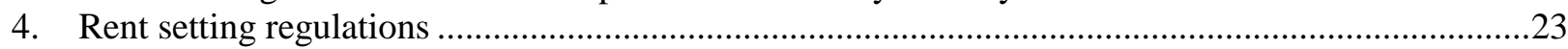

4.1 The Netherlands: The disadvantages of regulating the whole rental market..............................24

4.2 Czech Republic: partial deregulation leads to split between new and existing contracts...........25

4.3 Experiences of deregulation: Finland and the Czech Republic ...............................................26

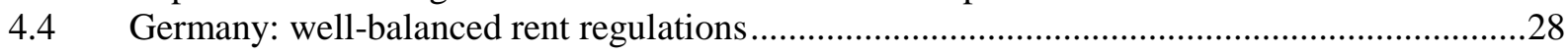

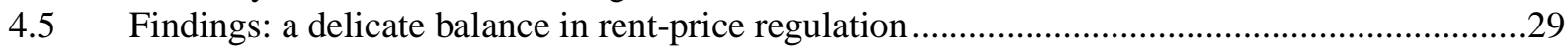

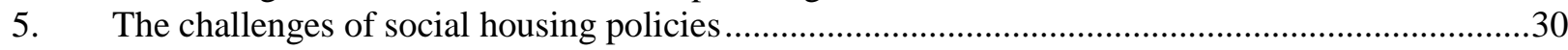

5.1 The dominance of social landlords on the Dutch housing market............................................31

5.2 Competition between non-profit actors: Finland ..........................................................................32

5.3 German social housing: a well-integrated sector ....................................................................32

5.4 Governance and oversight of social housing: a complex situation in the Czech Republic ........33

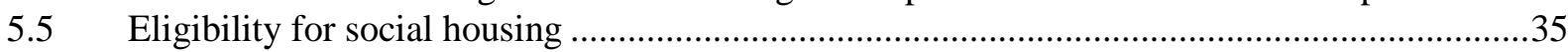

5.6 Findings: less distortive and more efficient social housing policies .......................................36

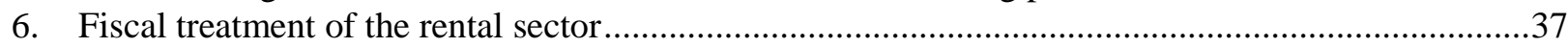

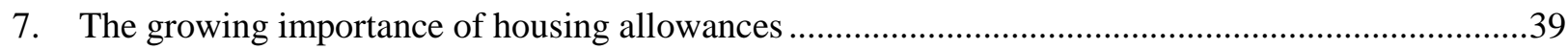

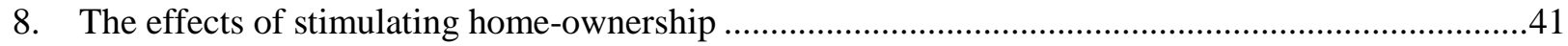

8.1 The risks of strong subsidisation of home-ownership ............................................................

8.2 The development of an owner-occupied market in the Czech Republic ...................................46

8.3 The German housing market shows the benefits of tenure neutrality ........................................48

8.4 Findings: the pitfalls of stimulating home-ownership ..............................................................4

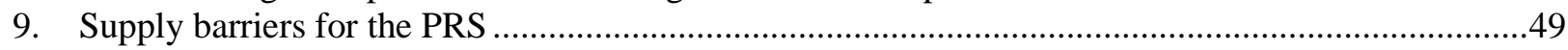

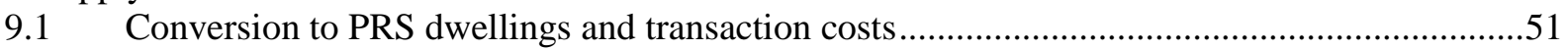

9.2 Crowding out PRS supply through local targets for social housing ...........................................52

10. Conclusions: How to create a level playing field for the PRS? ..................................................53

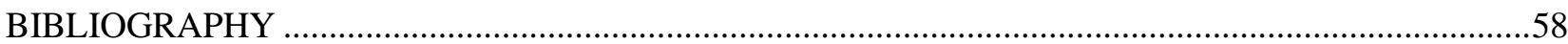




\section{Tables}

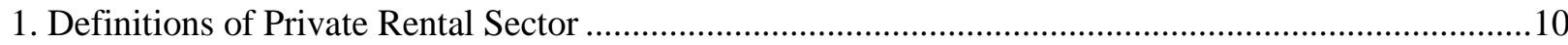

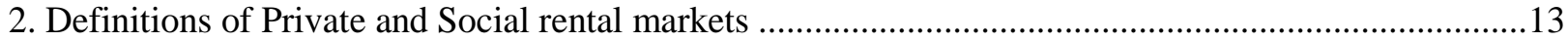

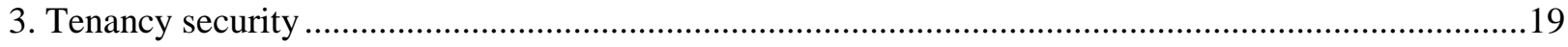

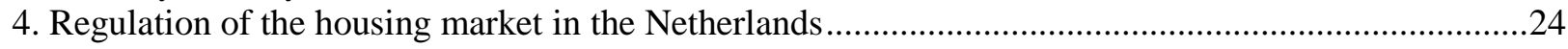

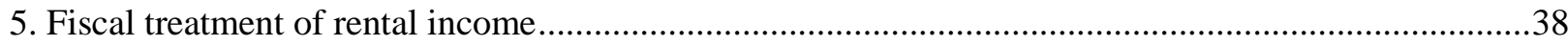

\section{Figures}

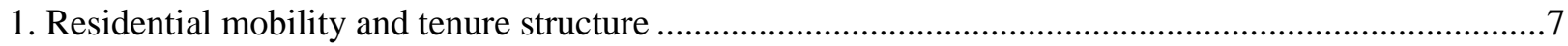

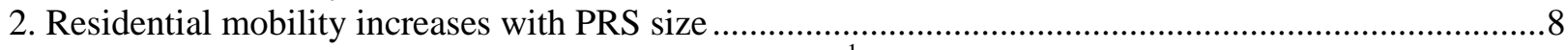

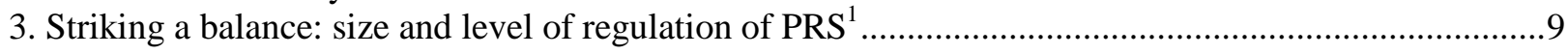

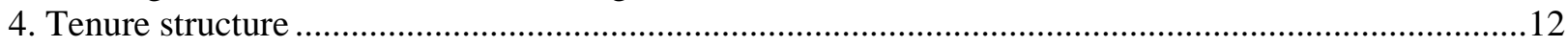

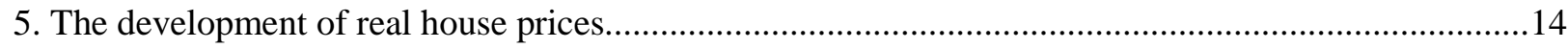

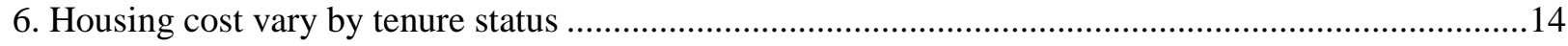

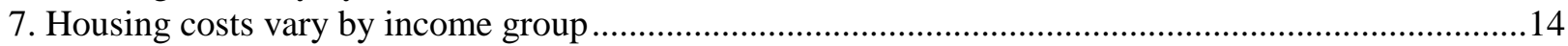

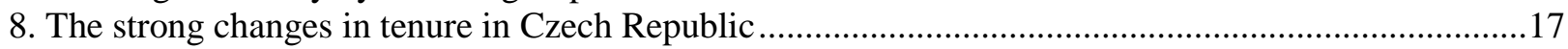

9. PRS size decreases with higher household mortgage debt .............................................................42

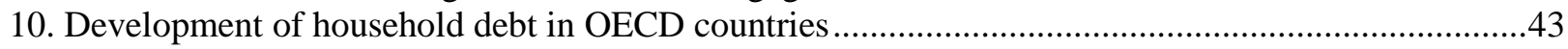

11. Large differences in tax relief on debt financing of home-ownership, 2009 ....................................44

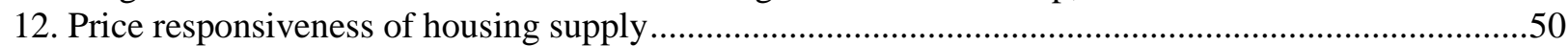

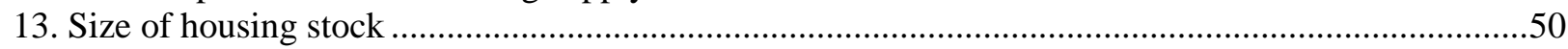

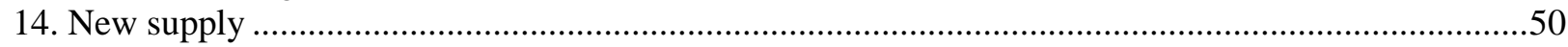

\section{Boxes}

Box 1. PRS definition: a difficult cross-country comparison ..................................................................10

Box 2. A worrying trend of increasing rent regulation in Germany .......................................................28

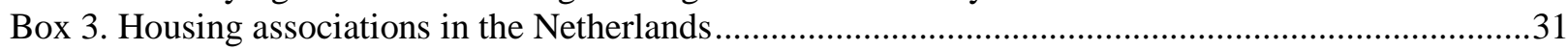

Box 4. Local governance and privatisation of public housing in Prague...................................................34

Box 5. The introduction of a tax for landlords in the Netherlands .......................................................39

Box 6.The reduction of mortgage interest deductibility in Finland.......................................................46

Box 7. Saving for your own home: Buildings saving schemes in Germany and the Czech Republic.......47

Box 8. Helsinki faces challenges to increase supply and a complex governance situation ........................52 


\title{
A REVIVAL OF THE PRIVATE RENTAL SECTOR OF THE HOUSING MARKET?
}

\section{LESSONS FROM GERMANY, FINLAND, THE CZECH REPUBLIC AND THE NETHERLANDS}

\author{
By Rik De Boer and Rosamaria Bitetti ${ }^{1}$
}

Introduction

\subsection{The growing importance of the private rental sector}

1. This article studies ways to stimulate the private rental sector (PRS) of the housing market - and compares the experiences with policies and reforms in Germany, the Netherlands, Finland and the Czech Republic. Although in many west European countries the PRS has decreased in importance since the Second World War (Lux \& Sunega 2010; University of Cambridge 2012), several developments indicate a growing importance of a well-functioning private rental segment on the housing markets.

2. In the aftermath of the 2008 financial and economic crisis, budget constraints on resources which governments can allocate for different housing policies (supply subsidies for social housing, fiscal subsidies for home-ownership, housing allowances) increase the importance of the PRS. "The restructuring of welfare states in association with demographic and social change, labour force mobility and greater housing market diversity, has led to increased interest in the PRS as a place to live, an investment opportunity and a means of providing flexibility in housing systems” (Hulse ea. 2010, p. 139). Policies meant to improve the PRS are becoming an important instrument to assure housing availability and affordability, when other welfare instruments are reduced or need to be better targeted in order to use resources more efficiently. In addition, the post-2008 decrease of house prices that is visible in many OECD countries has highlighted that home-ownership entails financial risks for consumers, banks and governments: this shows the risks of unbalanced housing policies in favour of the owner-occupied sector.

3. The private rental sector (PRS) plays an important role on the housing market, by providing an housing option to a section of population who is not willing or able to enter the owner-occupied market or has no access to the social housing market, due to ineligibility or inefficiencies such as long waiting lists. It should be taken into consideration that a section of the population can be better served if the private rental option in the housing market is improved: the number of young people, singles and childless couples is growing as the age at which people start a family has generally risen in most OECD countries (OECD

1. Rik De Boer is with the Dutch Ministry of the Interior and Kingdom Relations; Rosamaria Bittetti, is a Researcher at Luiss LAPS, Luiss Guido Carli, Rome. OECD Working Papers should not be reported as representing the official views of the OECD or of its member countries. The opinions expressed and arguments employed are those of the authors. The research was supported by a voluntary contribution from the Dutch Ministry of the Interior and Kingdom Relations and supervised by Jens Høj and Andreas Wörgötter from the OECD Economics Department. The main findings of this project were discussed with the participants of the Seminar on "A Revival of the Private Rental Sector of the Housing Market?" on 27 June 2014 at the OECD Economics Department in Paris. Special thanks go to Christophe André and Willem Adema from the OECD Economics Department and Directorate for Employment, Labour and Social Affairs, respectively, for helpful comments and suggestions. We would also like to extend our thanks to the involved national administrations for their helpful support, submissions and comments. Finally, this project would not have been possible without the confidence and support of senior management in the OECD Economics Department and the Dutch Ministry of the Interior and Kingdom Relations. 
2013). As labour markets tend to become more flexible, it will become more important for households to adapt the housing situation to changing economic circumstances, which might include increased national and international mobility. However, as shown in Figure 1, home-owners and social tenants tend to move less than private tenants in most OECD countries and the PRS is associated with more residential mobility across OECD countries (Andrews et al. 2011, p. 9). The reduced mobility in other tenures is due to the high investments needed for owner occupancy, transaction costs and lock-in effects in social rental housing, which can result in inefficient use of both public and private resources (Høj 2011).

Figure 1. Residential mobility is highest in PRS

Difference in probability to move relative to tenant in private rental market

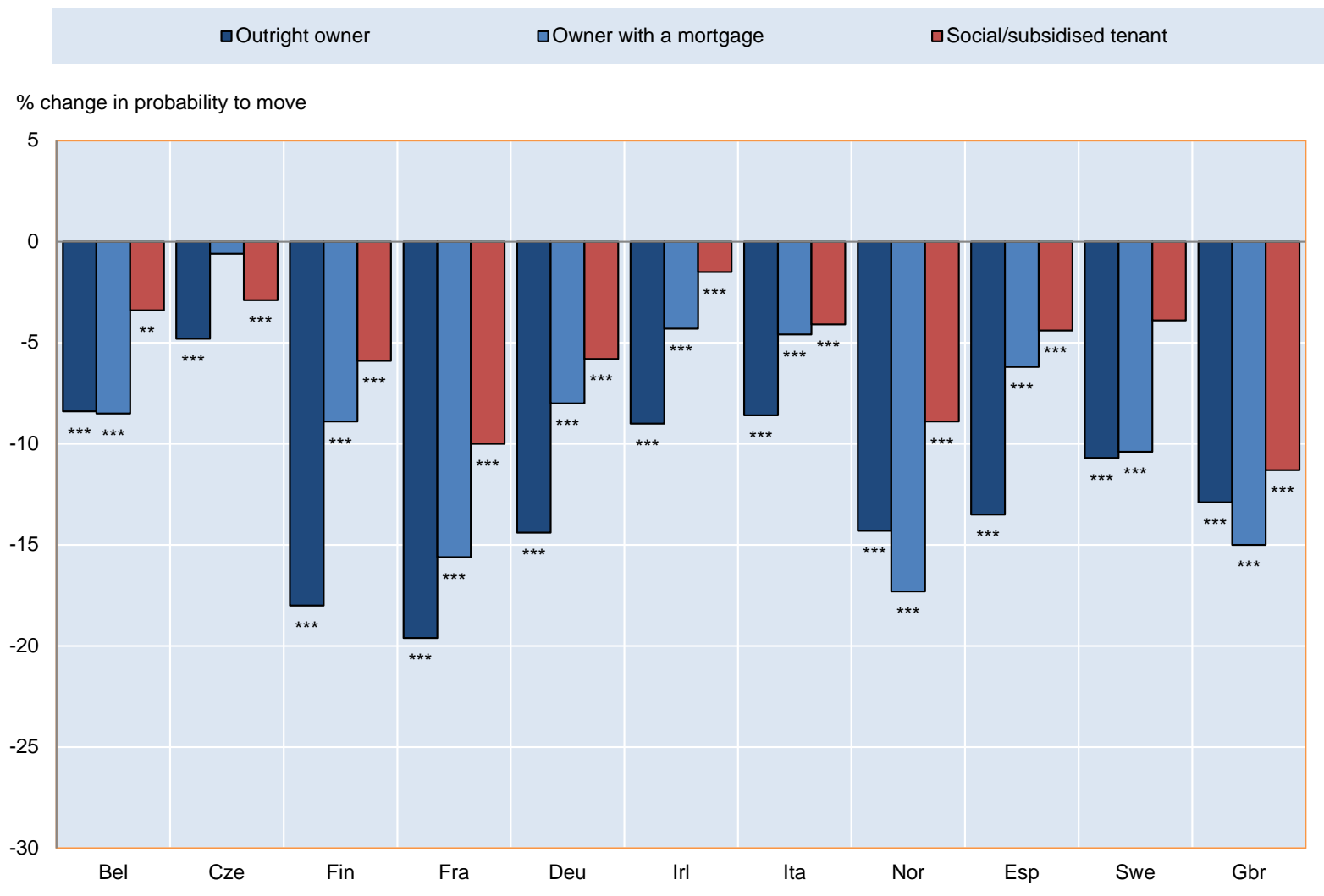

Source: Andrews et al., 2011

4. In order to address these developments it is therefore important to look at ways in which the development of the private rental market can be stimulated, in order to 'revive' this important part of the housing market. A well-functioning PRS can provide a housing option to increasing demand, thus promoting flexibility, to make it easier to move with changing job opportunities or to adapt to changing family circumstances and to reduce the macroeconomic risks of home-ownership (André \& Garcia 2012, p. 13). In most of the countries for which comparable data is available a larger PRS is associated with larger residential mobility - although there is considerable variation among countries (Figure 2). Therefore, neutrality in housing policies can improve the functioning of the housing market, lead to less distortion of consumer tenure choice and have positive effects for the wider economy. 
Figure 2. Residential mobility increases with PRS size

\begin{abstract}
Percentage of households that changed residence within a 2-year period ${ }^{1}$, Market rental dwellings as $\%$ of total dwellings
\end{abstract}

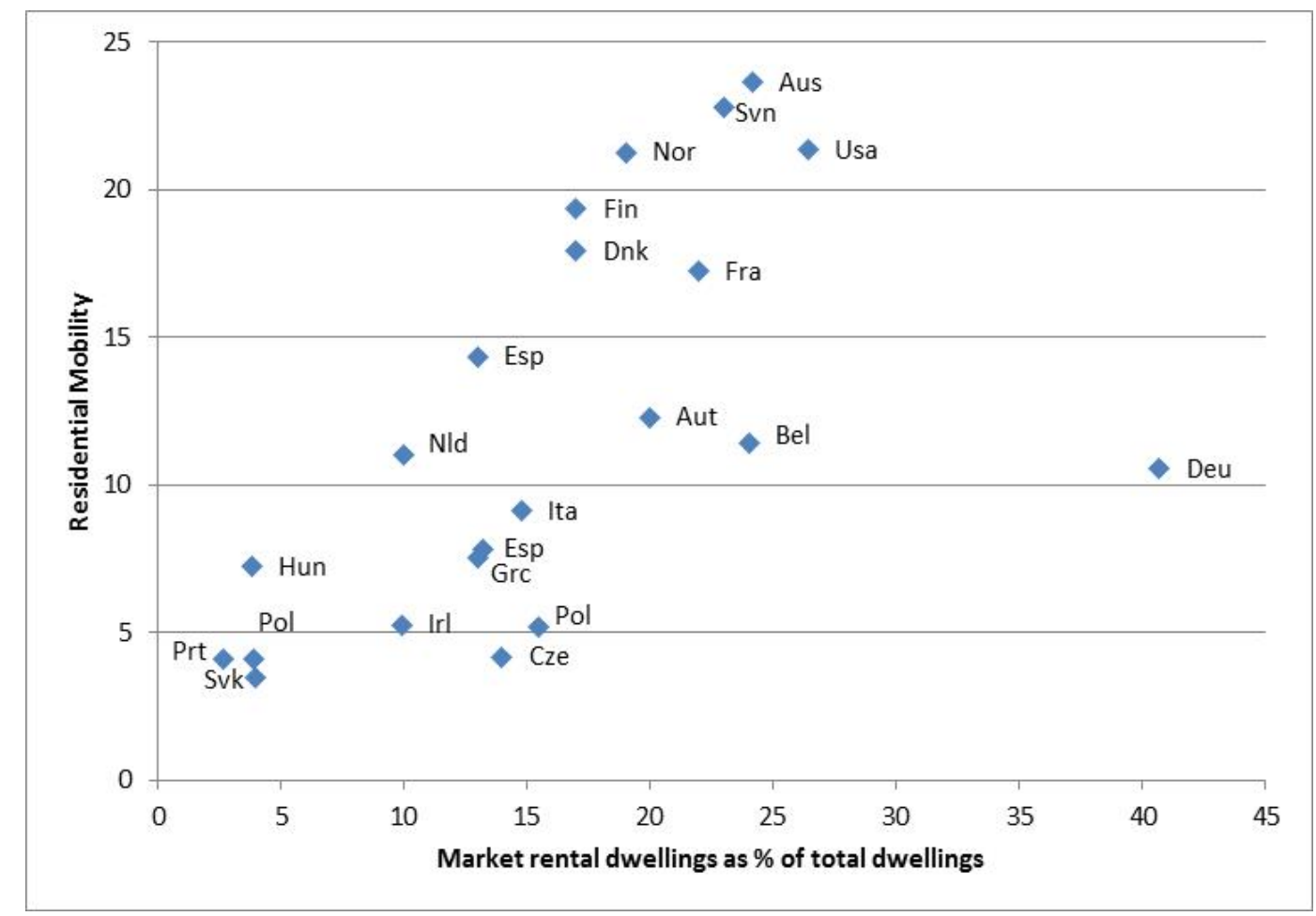

1. Calculations based on 2007 EU-SILC Database

Source: Andrews et al., 2011, National statistic accounts, Country reports

\title{
1.2 The diversity of housing markets and housing policies
}

5. This article will look at the functioning of the PRS within the broader context of the housing market, which essentially includes the three interlinked sectors: owner-occupied housing, social housing and private rental housing. Those sectors are all affected by demographics, income developments, costs for renting and buying on the demand side and by construction and land costs and competition on the market on the supply-side. Housing markets are influenced by a complex set of policy instruments, for instance legal rules on ownership and tenancy, fiscal policies, rent control, planning and building regulations (see also Andrews et al. 2011). Governments intervene in housing markets, because of the important role that housing plays in society - for a typical household housing is the single largest expense - and to address the market failures that exist on housing markets. These policies have different and sometimes contrasting goals and aim to reduce segregation, prevent negative neighbourhood externalities, provide affordable housing for people in need, reduce information and power imbalances between different parties, create clear legal frameworks for all actors and prevent unbalanced market developments.

6. There is a great diversity and heterogeneity between countries in regulations that affect the housing market and the rental sector. Earlier studies that sought to classify regulation of different housing markets and the PRS conclude that there is great diversity of measures (University of Cambridge 2012; Lux \& Sunega 2010; O’Sullivan \& DeDecker 2007; Haffner ea. 2009; Andrews ea. 2011; Boulhol 2011; Hulse ea. 2010). These studies also showed that there is no straightforward relationship between the degree of regulation and the functioning and size of the PRS (Figure 3). For instance deregulation of the social 
rental sector does not automatically lead to a larger and stable PRS (University of Cambridge 2012; Lux \& Sunega 2010): in fact, countries with the largest PRS shares of the housing stock have 'medium' levels of regulation for the PRS, such as Germany and Switzerland. And countries with low regulation for PRS - for instance weak tenancy protection or very liberal rules for rent setting in the PRS - do not have large PRS shares (University of Cambridge 2012).

Figure 3. Striking a balance: size and level of regulation of PRS ${ }^{1}$

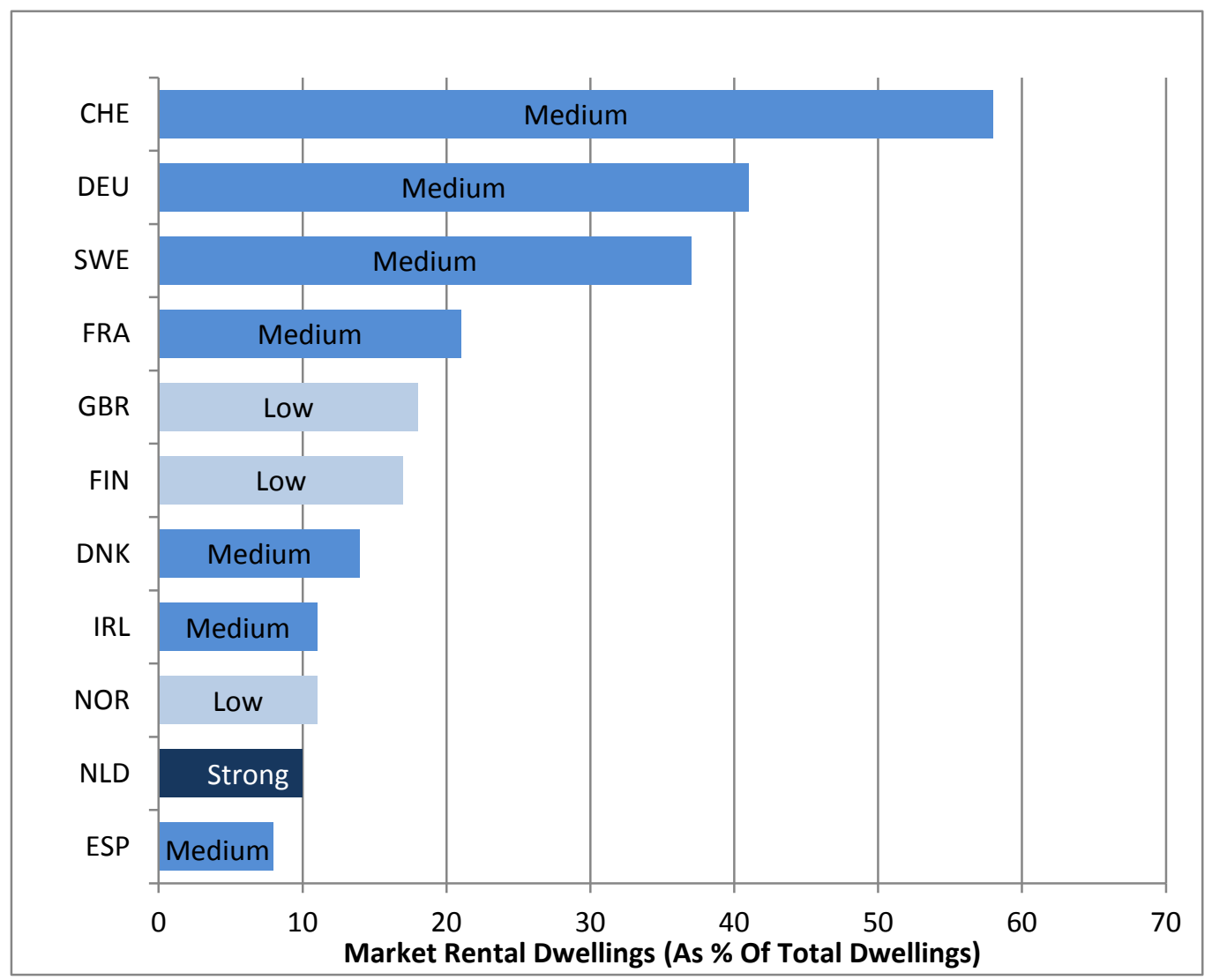

1. Regulatory levels from University of Cambridge 2012

Source: University of Cambridge 2012, Andrews et al., 2011

7. This heterogeneity of measures and complex trade-offs between different and conflicting policies are hardly captured by a cross-country study on large number of cases. It is our conviction that the exact design of regulations, the local housing market situation and broader institutional context matter a great deal for the functioning of the housing market, and therefore an in-depth approach of four case studies is chosen. Also comparable statistics on housing - or even a common definition of PRS - are difficult to develop in a comparative study, as there are large national differences (Box 1). As a consequence, it is meaningless to analyse PRS regulation by itself but it needs to be compared with the broad scope of housing policies, ranging from tenancy security and rent price regulations, to subsidies for owner-occupied housing and supply barriers. An important aspect of this approach is to show how housing market regulations need to balance the interests of different stakeholders - tenants, owner-occupiers, social and private landlords, and which trade-offs can be observed within and between tenures. 


\section{Box 1. PRS definition: a difficult cross-country comparison}

In this research the function of the PRS is considered as the for-profit part of the rental market. It is therefore contrasted with both social housing and owner-occupied housing. Social housing is "conventionally defined as residential accommodation provided at sub-market prices by state or not-for-profit landlords and allocated according to administrative criteria rather than price" (Fitzpatrick \& Pawson 2013, p. 2). The social housing sector thus seeks to provide affordable housing with no or only moderate profits, and entry and rent-setting might be more regulated than in the private sector - although as this article will show differences between private and social renting can differ substantially across countries (see Haffner ea. 2009) and can sometimes become 'blurred' (Hulse ea. 2010). The difference between PRS and owner-occupied housing is more clear-cut: in owneroccupied housing consumers act as investors in durable goods, whereas in rental housing the consumers do not. As these three market sectors are interlinked, as the different tenures can be partial substitutes for both consumers and producers, this article focuses on all three tenures of the housing market.

Definitions for PRS differ widely across countries (Scanlon \& Kochan 2011; University of Cambridge 2012). As the researchers from the University of Cambridge conclude: "In practice the classification systems in national official statistics are informed by national traditions and the structure of national housing markets - so in one country the definition of the PRS may be based solely on ownership; in another on market allocation; while in a third it may be the absence of subsidy that defines it. International statistics tend simply to accept these national definitions. As a result, simple data comparisons are difficult to interpret, even for apparently basic questions such as size. In the majority of countries the definition of the PRS is based on ownership."(University of Cambridge 2012, p. 120). When analyzing the PRS it is important to clarify that data are often poor and difficult to interpret, as the quality of housing data varies considerably among OECD countries. The table below gives an overview of different types of definitions of the PRS.

Table 1. Definitions of Private Rental Sector

\begin{tabular}{lll}
\hline \multicolumn{1}{c}{ Type of landlord or ownership } & Tenancy type - rental contracts & Use of dwelling \\
\hline Australia & Denmark & Finland \\
Austria & France & Ireland \\
Netherlands & Spain & Germany \\
Norway & & \\
Sweden & & \\
Switzerland & & \\
United Kingdom & & \\
\hline
\end{tabular}

Sources: Country reports, Scanlon and Kochan 2011, University of Cambridge 2012

In most countries the PRS definition is based on a distinction between owners: for instance in the Netherlands the definition is based on a difference between state or non-profit organizations that supply social housing and other owners - all rental stock that is not owned by non-profit actors is considered part of the PRS. In other countries, such as Denmark, it is differences in rental contracts that distinguish social from private rental. Also the use of the dwelling can differentiate social and private housing; In Germany the fact whether a dwelling receives state subsidies decides whether it is considered part of social or private housing, irrespective of the legal status of the owner. After the subsidy period ends the rental dwelling will automatically become part of the PRS. A more detailed explanation of PRS definitions in our case study countries will be presented in Section 2.

\subsection{A level playing field for the PRS: policies, barriers and trade-offs}

8. Rather than seeking to determine an overall or optimal level of regulation on housing markets, this article will analyse the trade-offs between different policies goals in housing policies, and regulatory impediments to a level playing field between the different segments of the housing market. In order to better account for the diversity of regulations in national private rental sectors, and to gain a better 
understanding of the developments and the relationships between the policies and their market outcomes this article uses an in-depth case study approach and presents the housing markets in the Czech Republic, Germany, Finland and the Netherlands (see overview in Section 2). The case analysis in this article is built on country reports by national experts ${ }^{2}$ and was supplemented with desk research and data collected through interviews with stakeholders of the local housing markets - such as landlords and tenants' associations, national and local government officials, private sector investors and social landlords. Whenever possible these experiences are put in a broader international perspective in order to present policy reforms that enabled a transition towards a better functioning PRS. In this way the article seeks to outline future policy options for governments seeking to stimulate the development of the PRS.

9. $\quad$ From all four cases important lessons can be learned, when identifying stimulants and barriers for the development of the PRS. Germany has one of the largest rental sectors in all OECD countries, and the PRS comprises $40 \%$ of the housing stock. The overall housing market policy provides a level playing field between different tenures, strong tenure protection as well as good incentives for investors. Finland has a smaller but growing PRS from 12\% of the housing stock in 1990 to $17 \%$ of the stock in 2012. Finland provides an interesting case for the effects of rent setting deregulation for the PRS, which changed from highly regulated to a very liberal system in the beginning of the 1990s. The Czech Republic shows the experiences of PRS reforms in a transition country. In contrast to other countries in Eastern Europe where owner-occupied housing is completely dominant, the Czech Republic has a relatively large rental share (about 22\%), and went through extensive reforms both of tenancy rights and rent control. The Czech case also shows imbalances between insiders and outsiders on the rental market. The Dutch housing market has a large rental sector (41\%). However, the role of PRS is marginal at a mere $10 \%$ of the total housing stock. Also is the housing market heavily influenced by various government policies: $93.5 \%$ of all rental dwellings are subject to government rent controls for existing and new tenancies, and social landlords have a dominant position on the rental market, owning more than three quarters of the total rental stock. Strong fiscal support for the owner-occupied sector and light financial regulations on mortgages generated one of the largest residential mortgage debts in all OECD countries.

10. This study seeks to identify impediments to a level playing field within and between the different segments of the housing market, as well as policies that enabled a transition towards a better functioning PRS. By clearly mapping the trade-offs and comparing the choices and experiences of different countries a clearer picture emerges on successful strategies to stimulate the PRS. The structure of this article is as follows: in section 2 a general overview of the developments on the housing markets in the four countries is presented. Then the different housing policies and trade-offs presented starting from those that most directly affect the rental sector: tenancy security and rent setting regulations (sections 3 and 4). The role of social housing and the effects for the PRS are discussed in Section 5. The issues related to fiscal and demand subsidisation are addressed in sections on tax measures for the rental sector (section 6) and demand subsidies through housing allowances (section 7). The stimulating policies for the owner-occupied sector and the consequences for the housing market are discussed in section 8. Finally, a number of barriers for supply of PRS housing will be discussed in section 9. This analysis - and frequent boxes on interesting national experiences - forms the basis for formulating policy lessons across countries, by showing which

2. Four country reports were written by national housing experts to support this research. These reports provide an in-depth overview of the position of the private rental sector in the four countries. For reasons of readability the reports are not constantly mentioned as a source. In case important conclusions are drawn from the country reports, this has been mentioned. We would like to thank Stefan Kofner (Hochschule Zittau/Görlitz, Germany) Martin Lux (Czech Academy of Sciences, Czech Republic) and Essi Eerola, Teemu Lyytikäinen and Tuukka Saarimaa (VATT Government Institute for Economic Research, Finland) for their valuable contributions to the OECD project. The 4 country reports can be obtained at request by sending an e-mail to Mikel Iñarritu (Mikel.INARRITU@oecd.org). 
regulation options are available to promote a well-functioning private rental sector, which forms the conclusion of this article (section 10).

\section{Overview of the case studies}

11. In this paragraph an overview of the 4 case studies is provided. First general information on developments on the housing markets is provided and the position of the PRS is discussed in short sections on each of the countries. Figure 4 shows that there is considerable variation in the tenure stocks between the countries, thus reflecting very different housing policies and outcomes. The PRS ranges from $10 \%$ in the Netherlands to $41 \%$ in Germany. Also the other tenures show large differences - with smaller social housing sectors in Germany and the Czech Republic than in the Netherlands. Home-ownership is low in Germany, where there is no strong fiscal subsidisation of home-ownership, and the highest in the Czech Republic - where home-ownership increased fast in the post-Communist era.

Figure 4. Tenure structure

Dwellings as a \% of dwelling stock

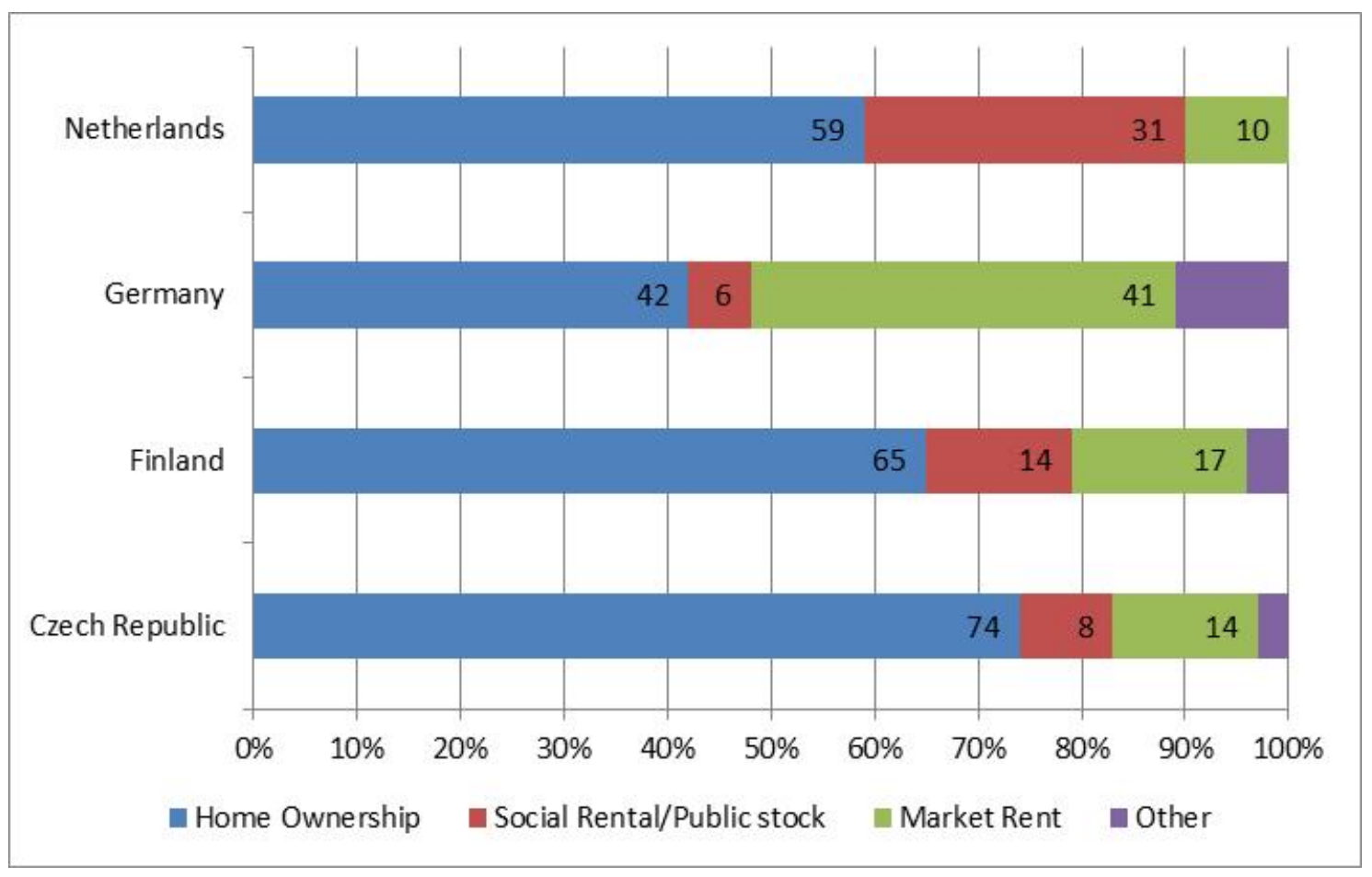

Source: Country reports

12. There are large differences in definitions of what the private rental sector actually is: in Finland and the Netherlands a social housing dwelling is owned by non-profit actors or municipalities that receive state subsidies. In Germany the legal status of the owner is of no concern: all types of owners can receive temporary state subsidies, and as long as the dwelling receives such subsidies it is considered social housing. After the subsidy period ends the dwelling moves to the private segment of the rental market. In the Czech Republic there are no separate definitions for private and social rental - all rental contracts have the same legal status. Since the difference between PRS and owner-occupied housing is clear-cut - in owner-occupied housing consumers act as investors in durable goods - the PRS definition comes often as a result of social housing policies and the way they affect the private market (Table 2). 
ECO/WKP(2014)66

Table 2. Definitions of Private and Social rental markets

\begin{tabular}{|c|c|c|c|}
\hline DEU & CZE & NLD & FIN \\
\hline \multicolumn{4}{|c|}{ Private Rental } \\
\hline $\begin{array}{l}\text { Private rental dwellings } \\
\text { are all non-subsidised } \\
\text { rental units owned by } \\
\text { private individuals or } \\
\text { private institutions. }\end{array}$ & $\begin{array}{l}\text { There is no special } \\
\text { definition of the PRS or } \\
\text { social housing sector. } \\
\text { Contractual relations are } \\
\text { governed by the general }\end{array}$ & $\begin{array}{l}\text { All non-social rental units } \\
\text { owned by institutions or } \\
\text { private persons can be } \\
\text { regarded as private } \\
\text { rental. }\end{array}$ & $\begin{array}{l}\text { Private rental dwellings } \\
\text { are non-subsidised rental } \\
\text { units owned by private } \\
\text { individuals or institutions. }\end{array}$ \\
\hline
\end{tabular}
regulations applicable to housing rental contracts set out in the Civil Code

\begin{tabular}{|c|c|c|c|}
\hline \multicolumn{4}{|c|}{ Social rental } \\
\hline $\begin{array}{l}\text { Social rental dwellings } \\
\text { are rental dwellings for } \\
\text { which temporary supply- } \\
\text { side financial aid is } \\
\text { received and rent caps } \\
\text { apply. Social housing is } \\
\text { irrespective of ownership: } \\
\text { both public and private } \\
\text { actors receive subsidies. } \\
\text { After the subsidy period } \\
\text { ends the dwelling moves } \\
\text { automatically to the } \\
\text { private rental sector. }\end{array}$ & $\begin{array}{l}\text { No separate definition. } \\
\text { The lacking framework } \\
\text { for social housing makes } \\
\text { it hard to determine } \\
\text { whether social housing } \\
\text { includes the complete } \\
\text { municipal public rental } \\
\text { stock or only the part that } \\
\text { is used for people with } \\
\text { lower incomes. }\end{array}$ & $\begin{array}{l}\text { Social rental dwellings } \\
\text { are subsidised, rental } \\
\text { dwellings, built and } \\
\text { rented out by non-profit } \\
\text { housing associations or } \\
\text { municipalities. }\end{array}$ & $\begin{array}{l}\text { A social rental dwelling is } \\
\text { financed with a state- } \\
\text { subsidised housing loan } \\
\text { and owned by a non- } \\
\text { profit actor. It concerns } \\
\text { both municipalities and } \\
\text { other non-profit actors. } \\
\text { Rents are cost-based in } \\
\text { social housing. }\end{array}$ \\
\hline
\end{tabular}

Source: Country reports, Scanlon \& Kochan 2011, University of Cambridge 2012

13. Also the developments of housing prices on the owner-occupied market show differences between the countries (Figure 5). Finland and the Netherlands show a strong increase in prices in the years before the economic crisis - which was in line with the main developments in OECD countries. After the 2008 crisis the prices decreased substantially faster in the Netherlands than in other OECD countries. Decreases since 2008 can also be in Finland - where prices currently are already close to pre-crisis levels and the Czech Republic, where prices are stabilising after a large fall. These developments may reflect to some extent the effects of sponsoring of home-ownership in these countries. The stability of the German housing market can be witnessed from the price developments over recent years. The German housing market was not negatively affected by the economic crisis. On the contrary, in fact the prices of owneroccupied housing and rental prices have been rising since 2010, in line with the strong economic performance in Germany, after a long period of steadily decreasing house prices. Figures 6 and 7 show that housing costs are generally higher in the Netherlands and Germany and lower in Finland. Problems with high shares of housing costs (above $40 \%$ of income) are witnessed more amongst tenants than among owners across the countries, but are most pronounced in the Czech Republic and Germany, where one third of the tenants have high housing costs. 
Figure 5. The development of real house prices

seasonally adjusted, $2010=100$

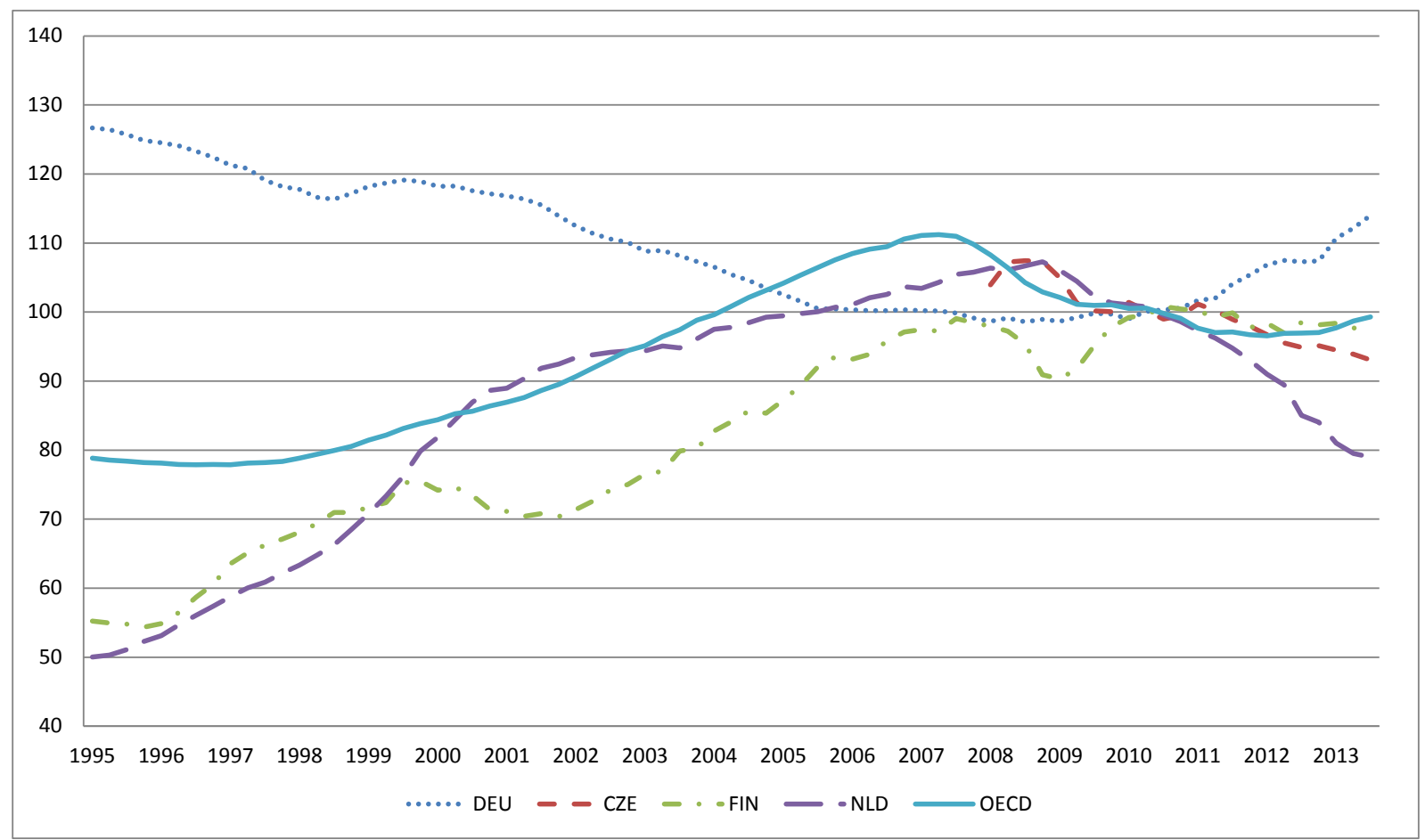

Source: OECD Factbook 2012

Figure 6. Housing cost vary by tenure status

$\%$ of the population with total housing costs over $40 \%$ of net disposable income

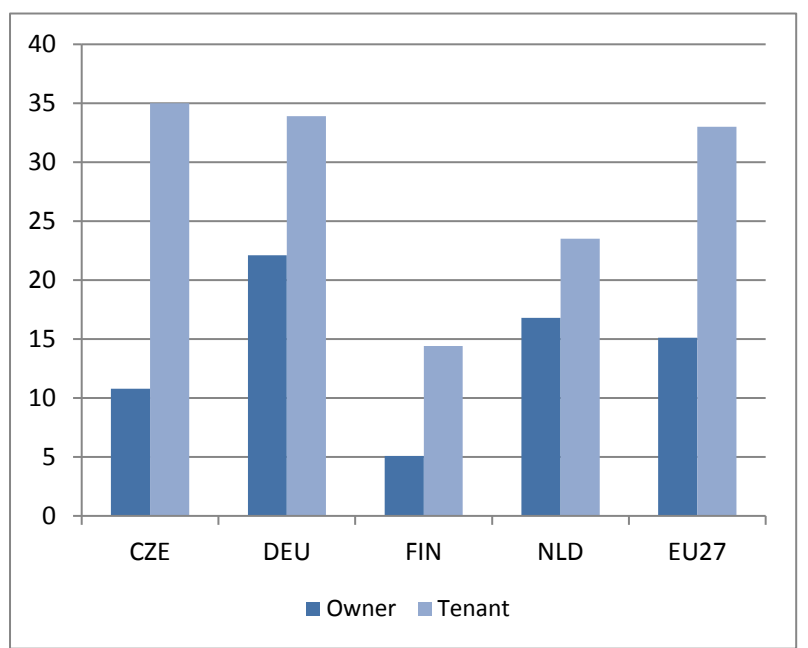

Source: Eurostat SILC

\section{Figure 7. Housing costs vary by income group}

Share of disposable household income ${ }^{1}$, by income group

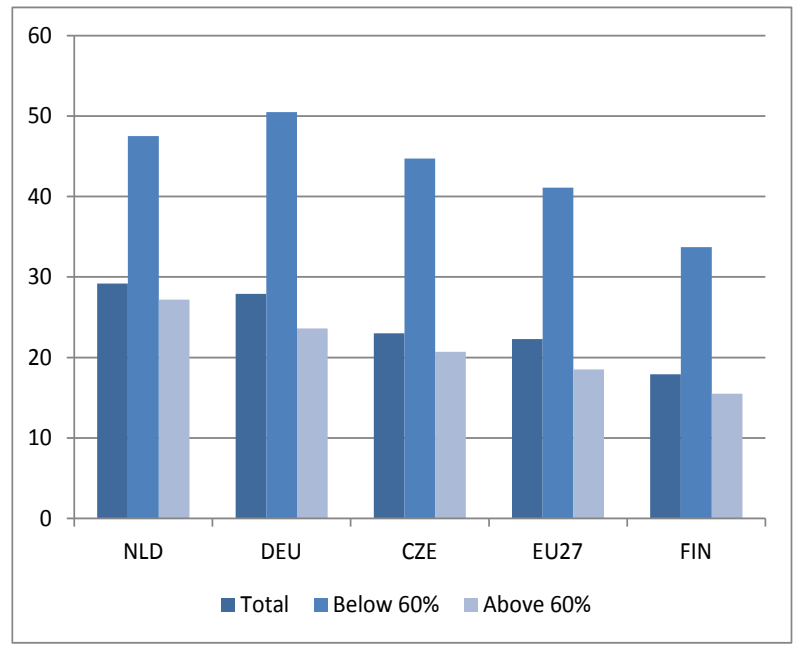

1. $\%$ of median equalised income Source: Eurostat SILC 


\subsection{Germany: a stable housing market with a well-functioning PRS}

14. Germany has one of the largest rental sectors in all OECD countries, and the PRS comprises 41\% of the housing stock and is a key pillar of the housing system. The German housing system is considered balanced, and the PRS is not hampered by many institutional barriers. The PRS serves broad layers of German society, as German households do not need to become home-owners to obtain high quality housing. In contrast to many other countries private renting is considered a secure and long-term option for many households. "The rental and home-owner markets are on the same footing in Germany, so that households can find appropriate residential property not only as a potential buyer but also as a tenant." (Voigtländer 2013, p. 10). Germany has combined protective regulation - strong contract protection and rent control - with extensive tax incentives for new construction of rental housing in the past (see also Kofner 2003). The basis of the German system of rent price formation for new contracts is the local reference rent ('Mietspiegel') - a locally determined average of the prices of new contracts and rent increases in existing contracts for dwellings of comparable quality. The rental regulations strike a balance between the interest of tenants and landlords, as the landlords have acceptable yields and tenants' rights are well protected: renting is considered by market players as a low risk investment with stable yields. Also there are generous tax deductions for landlords, and possibilities to increase the rent after modernisation, which has helped to maintain and improve the quality of the PRS stock. The tax system treats rental housing as an investment and hence provides for depreciation allowances, mortgage interest tax relief, deduction of maintenance costs and the possibility to deduct losses from the income tax base ('negative gearing').

15. There is not much competition between social housing and private rental housing, due to the temporary nature of social housing subsidies. In the past 20 years the share of social housing is shrinking and today only $4 \%$ of the housing stock is social housing. During the subsidy period for social housing there are rules for the entry and rent increases that are part of the subsidy contract between landlord and local government. At the end of the subsidy period - today typically about 10-15 years - the dwelling moves automatically to the PRS. The subsidies for social housing have been decentralised and scaled back and each year far more social dwellings move to the PRS than new social dwellings are constructed. The relatively low share of social housing does not give a complete picture of the affordable housing stock in Germany, as in total $6 \%$ of the dwellings are in public hands and these public landlords often rent out at affordable levels, also after the subsidy period for social housing expires. And also housing allowances help to make rents affordable in the private sector.

16. Another important aspect that contributes to the stability of the housing market is that German housing policies are largely tenure neutral. Owner-occupied housing is not stimulated extensively through fiscal policies, although there are benefits to stimulate a widely used building saving scheme ('Bausparen') and a residential pension savings scheme. Financial regulations for mortgage lending are prudent and relatively low LTVs are common practice. In comparison with other western countries Germany has a low home-ownership rate (42\% of the housing stock). The fiscal subsidisation does not generate a large push of demand towards the owner-occupied sector. The German residential market was not negatively affected by the economic crisis. In recent years prices and rents have been rising, in line with the strong economic performance and low interest rates. There are however regional differences: the price increases are most pronounced in the largest cities and in university cities, but at the same time there is oversupply in depopulating areas in Eastern Germany.

\subsection{Finland: a positive experience of housing market deregulation}

17. In Finland several important policy reforms with implications for the PRS have taken place in past 20 years. The general picture is that the housing market functions well in most of the country. $65 \%$ of Finnish households are owner-occupiers, and another $4 \%$ are in cooperative housing. There are roughly 
equal market shares for private rental (about 17\%) and social housing (14\%). Home-ownership is sponsored by various tax subsidies, such as mortgage tax deductibility and non-taxation of imputed rents. State-subsidized social rental housing covers little under half of all rental housing, but the share of social housing in new residential construction has been diminishing since the early 1990s.

18. The most important reforms regarding the rental housing market have been the abolition of strict rent control regulations in the beginning of the 1990s and the reductions in tax deductions for owneroccupied housing. Despite cuts in mortgage interest deduction, owner-occupied housing remains tax favoured relative to private rental housing. The complete reduction of rent price controls in the 1990s had important consequences for the PRS: Finland moved from a highly regulated rental regime to a very liberal regime. Rent price controls in the PRS were liberalised in 1993 for new contracts and in 1995 for existing contract in order to bring more rental apartments into the market, in the aftermath of an economic crisis and housing market bubble. Since the reform, Finland has no legal limits for initial rents or annual rent increases in the PRS, as there is complete contractual freedom, and tenancy security was reduced. This makes the Finnish rent system one of the most liberal in western countries (Lyytikäinen 2006). The rents in the social housing sector are cost-based and price increases are capped, but in large parts of the country there are no large price differences between social and private housing. The deregulation of the PRS was successful, as it increased the supply of PRS dwellings from 12\% of the housing stock in 1990 to $17 \%$ of the stock in 2012. The abolition of rent control increased rents in the PRS, but at the same time improved the availability of PRS dwellings, especially in the larger cities. As the housing market is balanced in most regions, deregulation did not lead to large problems.

19. There are however also inefficiencies and barriers for the functioning of the PRS market in Finland. The favourable tax treatment of owner-occupied housing makes home-ownership the desired tenure for most households. And the relatively large social housing stock provides barriers for the PRS, as eligibility is broad (70\% of the population), there is no means testing, and many tenants in social housing have higher incomes. In most parts of the country these differences might not lead to problems, but in tight markets - in the larger cities and especially in Helsinki - there are long waiting lists and people with higher incomes living in social housing. Insufficient supply of housing in the metropolitan region of Helsinki is a central concern, where a significant share of land is allocated to social housing, thus potentially crowding out PRS investments.

\subsection{Czech Republic: experiences from a housing market in transition}

20. The Czech Republic has seen many changes in the housing market in the transition from a planned to a market economy, and policies for both the rental and owner-occupied sector changed fundamentally. Under Communism the state supplied public housing at very low costs for the inhabitants. Various policy reforms caused substantial change in housing tenure structure. In 1991, home-ownership rate was 38\%, cooperative housing formed $19 \%$ and public rental $39 \%$ of the housing stock; private renting was almost non-existent. In 2013 home-ownership had increased to 65\%, due to state subsidisation, increased financing possibilities on the mortgage market, and selling of public housing to sitting tenants. Cooperative housing - a tenure between renting and owning, with a high security of tenure - formed $9 \%$ of the stock. Public housing was in strong descent, decreasing from 39\% of the stock in 1991 to $8-9 \%$ in 2013 (Figure 8). 
Figure 8. The strong changes in tenure in Czech Republic

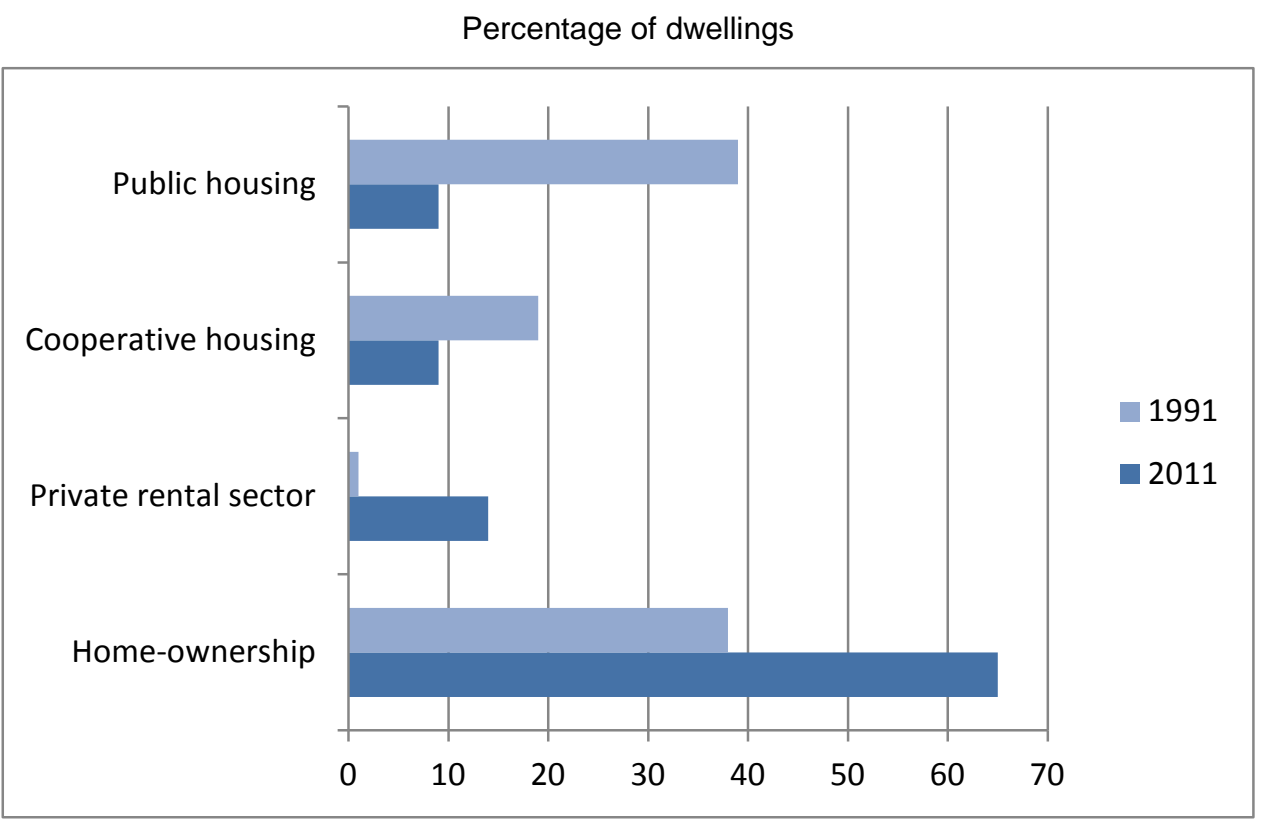

Source: Country report

21. The PRS plays an important role on the Czech housing market and it forms around $13-14 \%$ of the housing stock and has witnessed strong growth, contrary to experiences in most Western European countries. The Czech case is highly interesting, because of the experiences with deregulating tenancy rights and rent price controls. The Czech Republic gradually deregulated its rental market, and after two decades of strong rent control the rents for all running tenancies were finally liberalised at the end of 2012. There was however a very strong difference between new and existing rental contracts: new contracts were already completely liberalised in 1993, whereas for existing contracts rents were deregulated at a much slower pace, and sometimes capped at rates below cost-level, and it was almost impossible to end contracts or to evict non-paying tenants. This resulted in a severe split on the rental market.

22. However the Czech PRS did not develop into a strong and stable tenancy as in Germany. As the country report concluded private renting remained a kind of temporary housing for people at the start of their housing career or of housing for people who cannot afford to buy. The liberal tenancy security rules in the PRS made home-ownership the way to create a secure form of housing. The PRS became also partially a substitute for the social housing sector - as public housing is not subject to national rules or guidelines and municipalities have freedom to decide what to do with the public housing stock. The decrease of the public housing stock was mainly due to large scale privatisations to sitting tenants, often at prices far below the market value. Central government did not introduce social housing legislation or a long-term social housing strategy. Municipalities are almost exclusive owners of social housing and due to strong decentralization of power; they are also free to implement their own local social housing policies.

\subsection{The Netherlands: a highly regulated housing market with a marginal PRS}

23. The Dutch housing market has a dual structure: it is divided between an owner-occupied sector (59\%) and a rental sector (41\%). The PRS - rental dwellings from all private owners - has a marginal position and makes up only a small proportion of the total market: $23 \%$ of the rental market, or $10 \%$ of the total dwellings. There are several reasons for this marginal position of the PRS in the Netherlands. The main one is that the housing policies have led to a very high degree of regulation of both owner-occupied 
housing and social housing, and that policies for the housing market are far from tenure neutral. Housing policies in the Netherlands have been aimed at either social housing or the owner-occupied sector. The PRS is "crushed" between a large social rental sector, where not-for-profit housing associations operate in a wide segment of the market, and the owner-occupied sector, where owners receive substantial fiscal benefits. Demand for PRS is small and consists of younger and flexible people, who need access to the housing market on short notice, are unable to buy, or do not get access to social housing.

24. A first barrier is strong rent price regulation: $93.5 \%$ of all rental dwellings are regulated - and are thus subject to central government rent controls both for existing and new tenancies. The unregulated part of the rental market - without limits on initial rents or rent increases constitutes $6.5 \%$ of all rental dwellings, or $2.5 \%$ of the total housing stock. The strict rent regulation puts a cap on the yields and flexibility for landlords that are dependent on political decisions for their maximum revenues in regulated housing, and this reduces supply. A second and related factor is that the PRS has to 'compete' with housing associations that provide social housing. These housing associations have a dominant position on the Dutch rental market, owning 31\% of all dwellings in the Netherlands, or $77 \%$ of the rental market; this makes the Dutch social housing sector the largest of all OECD countries. Housing associations build and rent out high-quality rental dwellings at regulated rents, and do not have to make profits. There is a substantial system of state aid and regulation in place to ensure the investments in social housing and weaker neighbourhoods, leading to a crowding out of private investments in rental housing. These rental policies have led to a rental sector that is large in international comparison and of good quality and with low degrees of social segregation. However, there are also inefficiencies in the system: strong lock-in effects for tenants in regulated housing, long queues and many tenants with higher incomes living in social housing. Extensive fiscal sponsoring of the owner-occupied sector and increasing options for financing by financial deregulation in the 1990s have led to a strong stimulation of demand. Mortgage interest deductibility lowers housing costs on average by $40 \%$, but deductibility is regressive leading to large benefits for high income households. The residential mortgage debt is high in international comparison ( $€ 670$ billion, or $111 \%$ of GDP). This concentration of equity in the owner-occupied sector exposes households and banks to changes in the housing market situation. There are risks of over-indebtedness for consumers (25\% of home-owners currently have negative equity). Despite these barriers there are positive signs that PRS demand and supply can grow. Government efforts are aimed at reducing subsidisation of the owner-occupied sector and tightening lending standards for mortgages. Also measures are taken to improve the functioning of the rental sector - by enabling more room for rent increases and efforts to focus housing associations on their core task of providing affordable housing for people with lower incomes.

\section{Tenancy security and eviction procedures}

25. One of the fundamental policies regards the protection of tenancy and the eviction procedures that are in place, as they balance the interests of tenants and landlords and decide on the rules for openended contracts and valid reasons for ending such contracts (see Fitzpatrick \& Pawson 2013). They have a fundamental impact on supply and demand on the rental market. As Hulse and Milligan state "Legal conditions that offer tenants the right to occupy their homes, subject only to proven breaches of their lease agreements, and rigorous grounds for termination, provide a strong legal basis for continuous tenancy and thus de jure security of tenure forms a primary foundation for secure occupancy" (Hulse \& Milligan 2014, p. 14$)^{3}$.

26. There are thus several important reasons to regulate tenancy security and eviction as it protects tenants, especially if housing is scarce, and thus prevents that landlords could make excessive profits.

3. Hulse \& Milligan (2014) provide an extended literature review and international comparison on security of tenure for tenants. 
"More fundamentally, there are major issues of asymmetry and power inherent in a contract where neither side has full information and these problems become more extreme in times of scarcity or when the distribution of income is uneven”. (University of Cambridge 2012, p. 26). And as earlier OECD research states: "Most countries also regulate contractual aspects of tenant-landlord relations. The motivation for restricting freedom of contract is that bargaining between the landlord and tenant is often unbalanced, with either the risk that landlords exploit their market power or that tenants hold-up landlords' property" (Andrews ea 2011, p. 48). In order to address these imperfections all four countries therefore have a degree of asymmetrical protection: the protection of the tenant is usually strong relative to the landlord after a rental contract is concluded. As housing is a fundamental right, tenancy protection codified in civil law ensures that tenant cannot be evicted by landlords without justified reasons or that the rent contract can be changed unilaterally, as moving often is a large burden for tenants. Tenants can end open-term contracts with a notification period and do not have to provide a specific reason for ending the contract.

27. Based on evidence from the 4 case studies it will be argued that rules for tenancy security and eviction have a fundamental impact on the market (see Table 3). First, it will be shown that a strong protection of tenants can have positive effects on the functioning of the rental market - by using the strong tenancy security of Germany and the Netherlands as examples. Both countries are considered 'best practices' in the recent international comparison of tenancy security of nine countries by Hulse and Milligan (Hulse \& Milligan 2014, p. 15). Second it will be argued that a strong reduction of tenancy security will reduce demand for private rentals - as seems to be happening in Finland. Thirdly the Czech case will be used to show that too strong tenancy protection and inefficient eviction procedures hamper investments in the PRS.

Table 3. Tenancy security

\begin{tabular}{|c|c|c|c|c|}
\hline & Netherlands & Germany & Czech Republic & Finland \\
\hline $\begin{array}{l}\text { Typical tenancy } \\
\text { agreement }\end{array}$ & $\begin{array}{l}\text { Vast majority } \\
\text { indefinite. } \\
\text { Temporary under } \\
\text { conditions. }\end{array}$ & $\begin{array}{l}\text { Vast majority } \\
\text { indefinite term }\end{array}$ & $\begin{array}{l}\text { Older contracts are } \\
\text { typically indefinite } \\
\text { term. Tendency of } \\
\text { more temporary } \\
\text { contracts, although } \\
\text { indefinite is still } \\
\text { possible. }\end{array}$ & $\begin{array}{l}\text { Open term } \\
\text { contracts in social } \\
\text { housing. One year } \\
\text { contracts in PRS } \\
\text { that are } \\
\text { automatically } \\
\text { renewed }\end{array}$ \\
\hline $\begin{array}{l}\text { Tenant notice: } \\
\text { Period for indefinite } \\
\text { contract }\end{array}$ & $\begin{array}{l}1 \text { - } 3 \text { month, no } \\
\text { reasons needed }\end{array}$ & $\begin{array}{l}3 \text { months, no } \\
\text { reasons needed }\end{array}$ & $\begin{array}{l}3 \text { months, no } \\
\text { reasons needed }\end{array}$ & $\begin{array}{l}1 \text { month, no } \\
\text { reasons needed }\end{array}$ \\
\hline $\begin{array}{l}\text { Landlord notice: } \\
\text { period for indefinite } \\
\text { contract }\end{array}$ & 3 to 6 months & 3 to 9 months & 3 months & $\begin{array}{l}3 \text { months (for } \\
\text { leases < } 1 \text { year); } 6 \\
\text { months (for leases } \\
>\text { one year) }\end{array}$ \\
\hline $\begin{array}{l}\text { Permissible } \\
\text { reasons for eviction }\end{array}$ & $\begin{array}{l}\text { Rent arrears, grave } \\
\text { disturbance, urgent } \\
\text { personal use of the } \\
\text { landlord, realisation } \\
\text { of local zoning plan. }\end{array}$ & $\begin{array}{l}\text { Serious breaches } \\
\text { of the contract, rent } \\
\text { arrears, illegal sub- } \\
\text { letting, personal } \\
\text { use of the landlord }\end{array}$ & $\begin{array}{l}\text { Three months rent } \\
\text { arrears, if tenant } \\
\text { had other dwelling, } \\
\text { serious breaches of } \\
\text { the contract, } \\
\text { personal use of } \\
\text { landlord }\end{array}$ & $\begin{array}{l}\text { Unpaid rents of at } \\
\text { least two months, } \\
\text { unlawful transfer of } \\
\text { possession, sale of } \\
\text { the dwelling by the } \\
\text { landlord, personal } \\
\text { use }\end{array}$ \\
\hline $\begin{array}{l}\text { Length of eviction } \\
\text { procedures (2001) }\end{array}$ & 72 days & 331 days & 330 days & 120 days \\
\hline
\end{tabular}

Source: Country reports, Scanlon \& Kochan 2011, Djankov et al., 2003 


\subsection{Adequate tenancy security has positive consequences for the housing market}

28. Tenancy protection is an important part of the functioning of the rental market in the Netherlands and Germany. In Germany tenancy law is strong and considered well-balanced by all actors on the housing market: tenancy protection rules are at the core of the construction of renting as a tenure. They are the basis for the expectation of every tenant that renting provides long-term security of tenure. The balancing of interests between tenants and landlords is a central feature of the German housing market and tenancy security has been largely unchanged for decades. Rental housing is regarded as a stable and reliable tenure, almost as secure as owner-occupied housing.

29. Tenure security is asymmetrical: once a rental agreement is concluded the landlord is in a structurally weak position. Dismissal without notice is only possible in case of serious breaches of the contract (illegal sub-letting, non-payment). The German rental protection is so strong that if the tenant pays the rent it is almost impossible to end the contract, unless the landlord needs the apartment for himself. Even if the landlord's cancellation of the contract is legitimate, the tenant does not have to move out, if he is subject to hardship, and reasons can be as diverse as no adequate alternatives, pregnancy, low income, disability, infirmity or upcoming exams. The dismissal protection in itself is however not a considerable disincentive to rental investments, as it also fosters long-term demand for renting. Almost all rental agreements are concluded for an indefinite time, which keeps tenants flexible and in turn promotes labour market mobility. There are no policy initiatives or discussions on amending the tenancy protection laws. Kofner concludes in the country report that the strong tenancy security has in fact allowed the rental sector to reach its current size, as the largest tenure on the market.

30. The same general picture emerges in the Netherlands, where tenancy laws and tenancy protection are considered to be strong and rental contracts are generally open-ended, and there are specific rules for ending a contract for a landlord. Tenants can end contracts, and do not need a specific reason. Fixed-term contracts can only be cancelled prematurely if both tenant and landlord agree. As in Germany strong tenancy security is not considered a barrier for the functioning of the Dutch housing market. For both investors and tenants a high security of tenure creates a stable and long-term demand for rental dwellings and investors profit from stable incomes. Tenants, investors and government all agree that it is very beneficial that there is strong security of tenure, and this is an important asset for the Dutch rental market. As there is a fair and effective judicial system if there are problems with a tenant, strong tenancy protection does not pose problems for most landlords. Only for smaller individual investors the tenancy security might be a problem - for instance those who want to temporarily rent out their own dwelling and have to obtain permission from the bank.

\subsection{Substantially reducing tenancy security affects long-term demand}

31. In Finland there is also tenancy protection, but it is less strong than in the Dutch and German case. The most important difference with the Dutch and German cases is that the sale of the dwelling is also a valid reason for contract termination. This possibility that the sale of a dwelling is a valid reason for terminating a contract was introduced in the deregulation of the rental market of the 1990s. This thus leads to less security of tenure in the Finnish case, and may have contributed to the conversion of private rental dwellings to owner-occupied housing. "The change in legislation reducing tenants' rights has arguably made private renting less attractive to prospective tenants" (University of Cambridge 2012, p. 125). Fixedterm contracts in Finland are more difficult to terminate during the period they cover, but after expiry no specific reason for not extending it is needed. The same rules apply for the PRS and social rental sector. In the social housing sector contracts are always permanent and probably the bulk of contracts are permanent in the PRS, too. Often, permanent contracts start with a 1 year fixed term period followed by automatic extension. Landlords use this possibility to screen longer term tenants. This weaker tenancy security changes the demand for the PRS market in Finland. The turnover rates in Finland are much higher in the 
PRS than in social housing and owner occupied sector, which is partly due to the flexibility of regulation (Figure 1 and Andrews ea 2011). The PRS regulations allow short term tenancies and lowers tenancy security in permanent tenancies. As the country report concludes: "The PRS might be unattractive for tenants, because of the risk of termination of the tenancy due to for example, selling the dwelling."

32. England is another example where strong differences in tenancy security between social housing and private renting can lead to problems and undercut demand - and here the differences between the two tenures are even larger than in Finland. Research by Fitzpatrick and Pawson shows that until 2011 "the overwhelming majority of social tenants in England enjoyed indefinite 'lifetime' security of tenure. In sharp contrast, since deregulation in 1989, most private tenants in England have held 'assured shorthold tenancies' which provide security for only fixed-term periods, typically 6 months. Upon expiry, unless another explicit contract is arranged, the tenancy reverts to 'monthly periodic' form. The landlord can then secure possession without grounds, providing the tenant with only 2 months' notice.” (Fitzpatrick \& Pawson 2013, pp.5-6) Because of these large differences, the PRS in England is much less secure for tenants, and demand is mainly restricted to people that do not have other options. The researchers conclude that lacking tenancy security in the PRS can be "a matter of growing concern, given the increased concentration of low-income households in that sector" (Fitzpatrick \& Pawson 2013, p. 8).

\subsection{Unbalanced tenancy protection and inefficient eviction procedures hamper PRS}

33. The Czech case deserves special attention as the changes over the last 20 years have been large. In the years after Communism there was extremely strong protection of existing rental contracts and the new leases where completely deregulated in the early 1990s. Landlords hardly had possibilities to raise the rents of existing contracts, or to end the contract. For instance rental contracts could be 'inherited': transferred by a tenant to his or her descendants. The only justifiable reasons for termination were rent arrears for three months, if the tenant had another dwelling or very serious breaches of the contract. Before the changes of the Civil Code, even in the case of justified notice the landlord had to secure substitute housing. The landlord had to offer a comparable substitute dwelling: it was common practice that when the tenant refused the third offer, the landlord took the case to the court and the tenant was evicted. On top of that the eviction procedures used to take between 2 and 3 years. This combination of too strong tenure security and cumbersome eviction procedures led to a black market and relatively high rent arrears.

34. Since 2000, consecutive reforms of civil law have been implemented to restore the balance between tenants and landlords. For example, originally the landlord had to turn to the court to pursue notice; by a later amendment, notice could be sent directly to the tenant who could turn to court if he disagreed. Also the obligations for alternative housing were weakened, as the tenant no longer has to agree with the alternative. Tenancy security will be deregulated further by the new Civil Code that will come into force in 2014. The landlord will be allowed, for example, to give a notice without a court order also when the dwelling is needed for personal use. The right of substitute housing will be practically abolished. Eviction procedures have been streamlined, and now eviction takes on average one year. The judicial proceedings that accompany justified eviction are still lengthy and private landlords continue to conclude fixed-term contracts, mostly one year. Eviction procedures in the past were considered a problem by all actors. The main problem might not be the legal provisions but rather the fact that court procedures in the Czech Republic in general take a long time, leading to financial risks for landlords with unpaying tenants. The lengthy eviction procedures are the reason why many temporary contracts are given out. It is agreed by the actors on the Czech market that the protection for existing contracts was too strong, and that it is beneficial for the market that there no longer is a difference between new and existing contracts on the market. However, the experts now ask whether the deregulation of tenancy protection has not gone too far - as Lux mentions in the country report. The abundance of temporary contracts leads to less tenancy security and pushes consumers to the owner-occupied sector. Currently renting in the private sector is 
considered a transitional and residual form of housing mostly for people at the start of their career or people that cannot afford to buy rather than a stable housing alternative to owner-occupation,.

\subsection{Findings: the fundamental importance of tenancy security}

35. Demand is heavily influenced by differences in tenancy security, which alter the structure of the rental market fundamentally. The regulatory rationale of tenancy protection recognises the fact that there can be imbalances in landlord-tenant relations - such as differences in wealth or possible housing alternatives for households. Tenancy protection therefore aims at counterbalancing the contractual power of the landlord by assigning non-negotiable rights to tenants in order to increase their security from losing their accommodation (Hirsch 2000). As such, the rationale behind tenancy regulation thus closely resembles that of employer-worker relations, and indeed in countries like Sweden housing regulation has been modelled on labour regulation (University of Cambridge 2012). Germany and the Netherlands show that strong tenancy protection is a pre-condition for long-term demand for rental dwellings. As Kofner concluded in the German country report: "One can even say that dismissal protection creates an important part of the demand for renting as a tenure". Landlords in the Netherlands and Germany also have an interest in strong tenancy security, because it creates the long-term demand for rental housing, and there are no calls for weakening tenancy security. It can be questioned whether it is effective to lower tenancy security, as it pushes more consumers towards the owner-occupied sector, where there is a high security of tenure. The end result might even be lower residential mobility, as owners move less than tenants.

36. The Czech and Finnish experiences show on the other hand that weaker tenancy protection- for instance that selling of a dwelling is a legitimate reason for contract termination as in Finland - leads to more flexible and temporary demand for rental housing. Weaker tenancy security shifts the target group of PRS to younger people, or those who cannot afford to buy. Consumers will favour stronger security of tenure in the owner-occupied sector or in cooperative housing, which are popular tenures in both these countries. Next to strong fiscal support for the owner-occupied sector, the lower degree of tenancy protection is one of the reasons why the (private) rental sector is seen as a more temporary form of tenure in Finland and the Czech Republic.

37. However: there are also adverse effects of too strong tenancy security, especially if there are no effective ways to increase rents or to evict tenants that do not pay, as could be seen in the Czech Republic before the reforms of the Civil Code. Sitting tenants were protected so strongly that effective management by landlords was impossible, and many landlords were forced to sell the apartments. The Czech situation clearly shows that large differences in tenancy security between existing and new tenants should be avoided, as they create lock-in effects for sitting tenants and accessibility problems for outsiders. The consecutive reforms of the Civil Code aimed to restore the balance between landlords and tenants.

38. Another important lesson is that (strong) tenancy security has to be coupled with effective eviction procedures, as landlords have to be sure that they can evict tenants that do not fulfil their contractual obligations. The German and Dutch cases show the benefits of this approach. The Czech case shows that without transparent and enforceable eviction procedures there are large risks for investors. The negative consequences of ineffective eviction procedures for landlords are often mentioned, but it is important to realise that ineffective eviction procedures actually also negatively affect future tenants, as the 'wrong' group of tenants is protected - namely tenants that do not pay. This leads to less accessibility of the rental market for new households. In recent years important improvements have been made, but temporary contracts have tended to become more common in the Czech Republic, in order to circumvent inefficient eviction procedures - thereby adding to the temporary status of the PRS. 


\section{4. $\quad$ Rent setting regulations}

39. Rent setting regulations influence the functioning of the rental market to a strong degree and can have important consequences for the PRS. Such rent setting regulations differ widely across countries, as rents can be capped to various degrees or can be completely liberalised. Most western countries moved away from strict nominal rent caps or 'first generation rent control' since the 1970s (Lind 2001). The following rent deregulations "led either to the introduction of a more market-friendly, 'second-generation' rent regulation regime (in most countries) or to almost total liberalisation of private rents (for instance, in the UK and Finland)" (Lux \& Sunega 2010 p. 351). Within countries differences can exist between regulation of new contracts and regulations for rent increases of sitting tenants. Lastly, there can be differences in regulation for PRS and social housing, or between regulated and unregulated segments of the market - as in the Netherlands. Essentially, such policy choices on rent setting regulations imply a balancing of interests between the certainty about (future) housing costs for tenants and the possibilities for yields by landlords. As with tenancy security, rent price protection can be too strong, but weak or no rent price protection affects the structure of the rental market as it can reduce demand for rental housing. The challenge is to find the right balance between protecting the interests of landlords, sitting tenants and new households. As earlier OECD research also concluded: "in the presence of fixed costs of moving and lack of available insurance against a sharp, unanticipated rent increase, well-designed rent control can be welfare-improving (...) On the one hand, absence of rent regulations can lead landlords to hold up tenants by unexpectedly raising rents, since moving costs make renters less mobile. On the other hand, excessively strict rental regulations (such as cumbersome eviction rules) can lead tenants to hold up landlords' property. Thus, rental regulations should strike a balance between landlords' and tenants' interests, create security of tenure and avoid market segmentation between sitting and new tenants." (Andrews ea. 2011, p. 52)

40. The case studies will indeed show that overly strict rent price protection has negative consequences for the housing market - the strict regulation of almost the complete rental market in the Netherlands and the market split in the Czech Republic before the deregulation of rent are important examples. It can be questioned whether it is effective to regulate the rents for large parts of the market - as is clearly the case in the Netherlands. Too strict rent price regulation protects insiders on the market strongly, but with adverse effects for outsiders. Rental price regulation can have negative consequences also for sitting tenants, as the regulations create lock-in effects: the consequence is that accessibility of the rental market deteriorates and that many people cannot move to dwellings that would better suit their current needs. Too strict rent control can lead to a push to the owner-occupied market for people that do not have access to the regulated market and can push up prices in the owner-occupied sector (Sachverständigenrat 2013, p. 467). There is thus a risk of 'overshooting' of rent setting regulation, and the negative consequences for the mobility and functioning of the housing market can outweigh the benefits.

41. The Finnish and Czech experiences will show that deregulation of too strict rent controls can have benefits for the market, as improved possibilities for yields for landlords led to a quick increase in supply after the deregulation and in the end to improved accessibility of the PRS in these two countries. However it is important to note that there are also downsides to weak or absent rent setting regulations, as they influence the structure of demand for the rental market. It can be questioned if a complete deregulation will always improve the position of the PRS. Landlords in Finland and the Czech Republic both have considerable freedom to determine rent in the PRS, and in combination with weaker tenancy protection this has lowered demand for rental housing. In these countries deregulation seems to have contributed to the status of renting as a temporary tenure and pushed consumers to owner-occupancy. Germany is an example of well-balanced rent regulations, as reasonable profits can be made by landlords, and there is room for market forces in the determination of rent prices, but there is at the same time considerable security for tenants about future price increases. 


\subsection{The Netherlands: The disadvantages of regulating the whole rental market}

42. The Dutch market is distorted by the fact that almost all rents are regulated with negative effects for the functioning of the housing market, and there are strong differences between the regulated and unregulated segments of the rental market. National government strongly regulates almost all rental prices, as regulations apply to 93\% of rental dwellings. There are rules for both new tenancies and rent increases in existing contracts - for all dwellings with a monthly rent below EUR $681^{4}$. The maximum initial rents are set based on a system of objective characteristics of the dwelling, including size, amenities, energy efficiency, and neighbourhood factors, but location or the market value of the dwelling are not important factors. Recently extra points have been introduced to reflect the market situation in tight housing markets better. Experts and investors indicate that in regions with tight markets this regulation of initial rents is a barrier, as it makes it harder to build smaller unregulated dwellings. Experts agree that the system of initial rents does not pose a problem in large parts of the country, because the maximum rents are well above the rent that can be asked on the market. National government sets a maximum for annual rent increases of all existing contracts with a rent below EUR 681: in the past decade this has often been at inflation level, only since 2013 have rent increased above inflation been possible. For dwellings with a monthly rent above EUR 681 - 'unregulated' or 'liberalised rental dwellings' the rules on initial rent setting and annual increases do not apply. These unregulated dwellings form only $6.5 \%$ of the total rental market (Table 4).

Table 4. Regulation of the housing market in the Netherlands

\begin{tabular}{lcr}
\hline \multicolumn{1}{c}{ Housing stock } & 2012 \\
\hline Owner-occupied & $60 \%$ \\
Social rental (owned by housing association) & $31 \%$ & \\
$\quad$ Of which regulated & & $96 \%$ \\
$\quad$ Of which unregulated & & $4 \%$ \\
\hline Private rental (other owners) & $9 \%$ & \\
$\quad$ Of which regulated & & $69 \%$ \\
$\quad$ Of which unregulated & & $31 \%$ \\
\hline
\end{tabular}

Source: Syswov / CBS huurenquête

43. The strict rent regulation in the Netherlands puts a cap on the yields and flexibility for landlords that are dependent on political decisions for their maximum revenues in regulated housing, and this reduces supply. The regulations on rent increases and initial rents lead to increased certainty about the price level, but they create strong lock-in effects for sitting tenants: $28 \%$ of households in dwellings of housing associations have an income above the income limit at entry of social housing of EUR 34220. Earlier research by the Netherlands Bureau for Economic Policy Analysis showed that these regulated rents formed a considerable implicit subsidy of approximately EUR 8 billion per year, or more than EUR 200 per rental dwelling per month (CPB 2010). Moving would lead to a 'harmonisation' of the rent level, and higher income households are no longer eligible for social housing. The government has therefore introduced higher maximum rent increases for all regulated dwellings. To support mobility in the regulated rental sector higher rent increases have been made possible for people with higher incomes although this requires a complex administrative procedure by government and landlords. Given that the rent levels have been kept regulated for a long time, the incentives for households with higher incomes to move from the rental sector might not be too large in the short term, as there are still considerable implicit subsidies. Also it can be questioned whether it will be possible for landlords to increase the rents in all

4. All rents with a monthly rent under €681,02 are regulated rents (2013). This boundary is indexed annually: in 2014 the maximum is increased to $€ 699,48$ 
regulated dwellings: over the past years a stronger concentration of people with lower incomes in the regulated rental sector can be witnessed, as people with higher incomes have moved to the owner-occupied sector.

44. The current situation in the Netherlands has led to a split market between regulated and unregulated tenancies: the differences of regulation are so large - very high rent setting protection in the regulated sector and no rent setting protection in the unregulated sector - that the PRS becomes unattractive for tenants with a regulated contract. Therefore the regulated part of the Dutch market is considered too large by investors and experts, as a rent of about EUR 681 is not a rent that can be afforded by people with lower incomes. Over $70 \%$ of the inhabitants of the regulated sector have an income below EUR 33000 - and net monthly incomes of about EUR 1 900; for these households a rent of over EUR 600 will be hard to afford. The very strict rent regulations lead to tensions between sitting tenants and newcomers on the market. The problem does not seem to be the quality or the quantity of rental housing, as the rental sector still comprises $40 \%$ of the Dutch housing market, but allocation is a central problem: irrespective of income, sitting tenants in regulated housing are protected strongly and incentivised not to move, and demand for the PRS is lowered, as high-quality social dwellings are available at regulated prices. There are also large differences between the rents of new and existing contracts and for the same type of flat - even within one building - different rent levels can exist depending on whether it is an older or a newer contract, thereby completely abandoning market logic. As Vandevyvere \& Zenthöfer conclude: "On balance, the current set-up [of the rental market] crowds out the private rental market and limits its size, impeding its buffer role also with respect to the purchase segment." (Vandevyvere \& Zenthöfer 2012, p. 16)

45. Problems related to a market split between PRS and social housing can be witnessed in Finland and to a lesser degree in Germany. In Finland rent regulation in the social rental sector is cost-based and has led to below market rents in tight markets, and there is no means testing for sitting tenants. Therefore, there are lock-in effects for people with higher incomes in social housing and there is decreased accessibility for outsiders. Also in Germany the rules for rent-setting in social housing are different. In social housing maximum rent and rent increases are set by the public authority that gives out the social housing subsidy. Especially long-term social tenants benefit from low rents and thus there are lock-in effects. But given the temporary nature of social housing supply subsidies - at the end of the subsidy period the social dwelling automatically loses its social status - and the fact that the social housing sector comprises only $4 \%$ of the total housing stock it is "probably not the greatest obstacle to labour market mobility in Germany" (Country report Germany).

\subsection{Czech Republic: partial deregulation leads to split between new and existing contracts}

46. The strongest market split of the 4 case studies emerged in the Czech Republic between existing contracts and new contracts. Free rent-setting for new contracts was enabled in the Czech Republic since 1993, to promote investments in rental housing. The segment for new tenancies operated under very liberal conditions: for new and vacated dwellings there were no caps on initial rent levels, subsequent rent reviews, or restrictions on the terms of tenancy - and investments in this part of the market increased substantially (section 4.3). However existing contracts in the Czech Republic were protected very strongly. Tenants with contracts concluded before 1993, the 'privileged tenants' had maximum rents set by national government - even rent freezes for existing contracts between 1999 and 2006. This was coupled with very strong tenancy security. As Lux puts it in the Country report: "The housing market thus split into two segments: the 'privileged' and 'non-privileged' segments. Instead of a universal policy towards the PRS as a whole, two extremely different regimes were applied to it. Strict first-generation rent control with openterm contracts and strong tenant protection for all running tenancies existed simultaneously with an extremely liberal system of no regulations on rent setting or lease term and no effective tenant protection for new tenancies." As a consequence most rental housing continued to be occupied by 'privileged' tenants 
up until 2005-8, as tenancy rules strongly favoured the sitting tenants. This exacerbated the problems of the rental market as it developed in the Communist era, such as a black market for regulated dwellings, problems of accessibility and affordability for outsiders and high rents for new deregulated tenancies. The negative consequences of very strict rent regulations were so large that many landlords - both private and public - decided to sell their rental dwellings with existing contracts. Under such strict control there was no effective way of managing the dwellings, because rent increases or rent termination were impossible. The split market between new and existing contracts was thus a main barrier for the further development of the PRS in the Czech Republic, as it changed demand for the PRS.

47. Despite the negative effects for the housing market, the deregulation took considerable time. The Czech Constitutional Court ruled that the rent freezes were unconstitutional already in 2001. However, it took until 2006 before a new act was adopted - and this was mainly due to the fact that a Polish case before the European Court led to fears that the Czech state would have to reimburse landlords for their losses, due to the strict rental regulation. The new act deregulated the rents for existing contracts in steps between 2007 and 2012. This led to an increase in regulated rents and a reduction in the gap between free market rents and regulated rents. Since 2012 all rents in both municipal and private rental segments and for both running and newly-signed rental contracts are deregulated, and no longer determined by the state. The positive effects of this deregulation are discussed in the next section.

\subsection{Experiences of deregulation: Finland and the Czech Republic}

48. The Finnish and Czech experiences with liberalising too strict rent regulation show that deregulation can have positive outcomes for the functioning of the market - in terms of PRS supply, competitiveness of the market and accessibility for outsiders. Also a more competitive market can prevent decreasing affordability, although in tight housing markets this remains an issue.

49. Finland already deregulated the rents in the 1990s, and therefore is an interesting 'test case' to assess whether the problems of too strict rent regulation and a market split between new and existing rental contracts that are witnessed in the Netherlands and the Czech Republic can be prevented by deregulating rent setting protection. As Lyytikäinen discusses in his overview of rent regulation in Finland the earlier rent setting regime since the 1970s was very strict, and government set maximum acceptable rents for initial rents and rent increases for all PRS dwellings. Maximums were set for different types of dwellings based on dwelling type, age, size and size of the municipality - thus showing many similarities with the current Dutch system of rent-setting regulation. Although the regulated system had as a goal to follow market developments, in reality the real average rent level fell, due to regulation (Lyytikäinen 2006).

50. The most important housing policy reform in Finland was the reduction of rent price controls for the PRS that led to a liberalised market with no limits on initial rent or subsequent rent reviews. In the case of long term rental agreements, the rent is typically reviewed annually. The size of rent increases must be specified in the lease agreement, and in most cases, the rent increases are based on the cost of living index. The deregulation was a consequence of the severe economic crisis in the early 1990s. In the 1980s the highly regulated financial markets in Finland were liberalised, which led to a large inflow of capital and increased mortgage financing. This led to a housing market bubble, a banking crisis and severe depression in the first years of 1990s (see also Vartia 2006). In 1991, the abolition of rent control was included in the government programme in reaction to the large problems on the housing market. The motivation was to bring more rental apartments into the market in reaction to the economic and housing market crisis.

51. The deregulation was successful, as it increased supply of PRS dwellings from $12 \%$ of the housing stock in 1990 to $17 \%$ of the stock in 2012, and especially in larger cities there is a competitive PRS. "While the number of private rented dwellings decreased in 1970-90 under rent control, the period 1990-1995 witnessed an increase of nearly 50\% in the number of private rented dwellings". (University of 
Cambridge 2012, p. 125) The increase of the PRS was especially fast in the years immediately after the rent deregulation and during the crisis in the owner-occupied market, reflecting increased possibilities for yields for landlords. Since 1995 the PRS has been increasing at a slower pace (André \& Garcia 2012). In the early 2000s owner-occupied housing was favoured, because of economic growth and low interest rates for mortgage credit. The deregulation also had a positive impact on the allocation of PRS dwellings: "During the rent controlled period, below market rents implied that those who managed to get a rentcontrolled dwelling had incentives to stay even if the dwelling did not match their preferences. In the rent control period households and dwellings were not as well matched as after the abolition of rent control. The implicit costs of this kind of mismatch offset much of the benefits of lower rents for tenants." (Country report Finland; see also Lyytikäinen 2006). In Finland there are currently no discussions to 're-regulate' the private market: no actors see further regulation as a good solution. As the housing market is balanced in most regions, the deregulation did not lead to large problems with affordability of the PRS. However, especially in the Helsinki metropolitan area there is a tight market with insufficient supply, which has led to increasing prices. In order to prevent to large price increases tenants and landlords associations have voluntarily agreed to set an annual maximum increase of $15 \%$ - this voluntary code of conduct is called 'fair rental practices'.

52. Also the Czech experiences with deregulation had positive outcomes for the private rental market, although the effects of the complete deregulation since 2012 can of course not yet be fully appreciated. The PRS grew strongly from almost zero in 1990 to 7\% in 1993 as a result of property restitution and to 13-14\% in 2011. The property restitution first created a PRS, and free market rents could be charged from 1993 for new contracts and since 2007 the rents for sitting tenants could be adjusted gradually to market rents. Because of the absence of limits on the initial rent for new tenancies and a shortage of rental housing for new households, a large number of small-scale investors entered the market. The growing competitiveness on the market cut investment yields and increased the financial attractiveness of the PRS for tenants: the average flat price in the owner-occupied sector increased between 2000 and 2008 by almost $200 \%$, whereas the increase in market rent was much more gradual - a growth of $64 \%$ (Lux \& Sunega 2010). Lux therefore concludes: "The rapid growth of the PRS and rent deregulation increased the relative financial attractiveness of private renting for tenants, but at the same time it substantially decreased private yields. The market quickly changed from supply-driven to demand-driven, and this increased its efficiency”. (Country report).

53. The experiences with deregulation of too strict rent setting had important benefits for the housing markets in Finland and the Czech Republic. At the same time it should be noted that a significant decrease of the rent setting protection for tenants also alters the demand on the market: the PRS is regarded by consumers as a temporary option - this can be seen in the Czech Republic and Finland, as in both countries private renters are younger and more mobile. It should be noted that this status of the PRS as temporary housing is not only a matter of rent setting regulation however: weaker tenancy security and strong fiscal subsidisation of home-ownership very likely also are important factors that contribute to the temporary status of private renting. The deregulation of rent setting regulations however further added to the temporary nature of the PRS in these 2 countries, as owner-occupied housing came to be regarded as the most stable tenure. The reduction of rent setting regulations - and especially the large differences between new and running tenancies in the past - contributed to the status of the PRS as a temporary option for people at the start of their housing career or for people that cannot afford to buy. As Martin Lux concludes in the country report: "The reforms of the PRS thus had two paradoxical effects in the Czech Republic: a quick increase in the supply of private renting was accompanied by structural changes in the demand for rental housing generally. The conditions unilaterally supporting the quick supply of new private rental dwellings at the same time constrained the long-term demand for them”. 


\subsection{Germany: well-balanced rent regulations}

54. Of the four cases Germany has struck a good balance in the rent setting regulations, as tenants, landlords and public actors consider it a system that balances the interests of investors and consumers in a good way. There is no push for liberalisation of the current tenancy and rent regulations. The German system of setting rents through the local reference rents (LRR) allows enough room for market forces and reasonable profits for landlords, but at the same time protects tenants against excessive rent increases although in the current system the protection of new households in tight housing markets in Germany is weak. The basis of the German system of rent price formation is the local reference rent ('Mietspiegel'), which is the most common method of rent setting regulation. ${ }^{5}$ The local reference rent is a locally determined average of the prices of new contracts and rent increases in existing contracts for dwellings of comparable quality. It is the market element in the rent control system, although it does not only reflect current market circumstances, as the rent increases of the past four years are used. For existing contracts the local reference rent gives a maximum, and there is an additional rent cap which limits the scope for rent increases over three years to a maximum of $20 \%$, even if the local reference rent would permit a higher rent increase. This form of rent price regulation is relatively flexible, and investors indicate that in practice it does not form a barrier for investment.

55. There is a difference in protection between existing contracts and new tenancies. In on-going contracts the rental price laws are largely respected and provide for a significant rent-capping effect in tight markets. There are legal protections in place to prevent too high initial rents: there is a legal provision which considers $20 \%$ above LRR inappropriate and usury - defined as exceeding the local reference rent by $50 \%$ - is a criminal offence. However, these legal provisions are dead letters in the law, as they are hardly enforced and only a handful of cases are brought before court. As Kofner puts it: "the laws are literally meaningless for the newly concluded tenancies, as legal protection is ineffective". This means that in reality initial rents in the PRS in Germany are unregulated. The difference in protection between sitting and new tenancies has resulted in large rental price differences for comparable housing quality in tight housing markets. As the rents in new contracts have been rising strongly in the past years, this has led to calls for further price regulation of rents. The country report shows in detail that in a number of urban hot spots (such as Hamburg, Munich) there are low vacancy rates and rent levels are far above average.

\section{Box 2. A worrying trend of increasing rent regulation in Germany}

In reaction to the rising rents in tight housing markets a tendency has emerged in recent years to introduce more caps on the rent levels, thereby leaving less room for market forces and thus possibly disturbing the balance that was found between security about price developments for tenants and investment possibilities for landlords. For instance the rent cap for existing contracts has been lowered from $20 \%$ to $15 \%$ in 3 years in tight markets to be decided at state level. This stricter rent cap is for instance applied in the whole states of Berlin and Hamburg, thus reducing possibilities for landlords to increase rents. And the current coalition proposes to introduce a 5 year rent cap for new contracts at a maximum of $10 \%$ above the local reference rent, in tight markets to be decided by the states. A cap for new tenancies, while favorable to tenants, represents a significant reduction of free rent setting, since this is precisely the segment where market forces were allowed to influence the local reference rents. The German economic council is critical about introducing caps, because of the disincentives for investment in the rental sector and insider/outsider problems on the housing market (Sachverständigenrat 2013, pp. 463-467).

5. Other allowed methods for setting rents are stepped rents (predetermined nominal rent increases) and index-based rent contracts, and the Mietspiegel and additional caps do not apply. 


\subsection{Findings: a delicate balance in rent-price regulation}

56. An important conclusion that emerges from the four case studies is that both 'over-regulation' and 'under-regulation' of rent setting can lead to a marginal PRS. There is a delicate balance between the interests of tenants and landlords. Too strong rent price protection can lead to dualisation problems of market. Whereas too weak protection changes the demand for the PRS and gives consumers a push to the owner-occupied sector. As the European Commission concluded in a recent overview of EU housing markets: "Regulation should strike the right balance between tenant and landlord incentives - i.e. creating security of tenancy and avoiding market segmentation between sitting and new tenants while ensuring landlords' property rights-as this can mitigate rental market inefficiencies and correct for market failures without contributing to housing market imbalances.” (European Commission 2014, p. 19) Also Lux and Sunega reach a similar conclusion, in a comparison of the PRS in Europe; countries with very strict rent regulation (such as Denmark, the Netherlands, France) do not have a stable PRS and this is attributed to the existence of risks for private investors. "Conversely, in some countries with the extreme liberal system of second-generation rent regulation (Finland, and since 2001 the UK) the share of private rental housing grew. However, the long-term stabilisation of the PRS is not observed in countries with the most liberal system of rent regulation (...) but rather in a country with a moderate system of second-generation rent regulation and stronger protection of the duration of a lease (Germany)” (Lux \& Sunega 2010, p. 357).

57. Another important lesson is that a complete rent deregulation, coupled with lowering tenancy security is a two-edged sword: it leads to a fast increase of PRS supply, but too liberal rules undercut demand. These twin developments can be witnessed both in Finland and the Czech Republic. The liberalisation of rent setting and tenancy security is followed by a rapid increase in supply of PRS housing in the short term. Reduced tenancy security undermines long-term demand, as contracts can be changed easily, and dwellings sold easily. The tenants are thus given an incentive to move to the owner-occupied sector, if they want strong tenure protection.

58. The Dutch case shows the disadvantages of regulating rent setting in almost the complete rental market, as the large differences between regulated and unregulated rents reduce supply and demand for the PRS. Also the market split in the Czech Republic between new and existing contracts had negative impacts on the rental market, before the rent regulations were deregulated. It can be questioned whether it is necessary to regulate the price of the whole rental market - as is the case in the Netherlands. The experiences with deregulation of the rental market in Finland show that the market will often also provide security about rent levels: maximum rent increases are put in almost all contracts, despite the fact that the government does not regulate these maximum increases. A negative consequence of this complete freedom is that the rent increases are completely dependent of the own negotiations of the tenant with the landlord.

59. The German rent-setting regulations are well-balanced: a localised system of regulation that follows market developments through local reference rents, and that balances security for tenants and flexibility for landlords. Although there are problems in tight markets, as an effective prevention of excessive rent increases and excessive rent demands is currently not in place. A more effective legal protection for new tenancies, without weakening the investment conditions for landlords too much, can improve the functioning of the market. The current proposal of the German government is moving away from the balanced model of rent-setting regulation, without making a convincing case.

60. Some countries are taking over the lessons of rent setting regulations in Germany. The Czech Republic is introducing a local reference rent, comparable to the German system, which is a development that can help making the price developments on the rental market more transparent. The Ministry of Regional Development is currently drafting the final regulations and setting up ways in which landlords and tenants can obtain the comparable rent levels. This is an important improvement for the rental market in the Czech Republic - and is considered so by all actors. This localised reference system is much 
preferred to the system of regulated rents in the past in which there was a single maximum rent for municipalities, based on their size, and irrespective of the quality of the dwelling. Also the Netherlands is proposing to introduce market elements in the point system for maximum and initial rents, in order to better reflect the value of the dwelling. Steps to introduce market elements in rent setting regulation in the Netherlands can improve the relationship between price and the quality of the rental dwellings, while at the same time creating a reasonable degree of security for tenants about price increases and maximum rents.

\section{The challenges of social housing policies}

61. Social housing is "conventionally defined as residential accommodation provided at sub-market prices by state or not-for-profit landlords and allocated according to administrative criteria rather than price” (Fitzpatrick \& Pawson, 2013 p. 2). Social housing thus serves as a means to secure affordable housing for people with lower incomes or special needs, and often social housing serves the purpose to minimise segregation through investments in weaker neighbourhoods. As this paragraph will show there are large differences between countries in the way in which social housing is provided, also there are large legal and financial differences - and thus the conventional definition of social housing cannot easily be applied to all countries. The differences in size of the social housing sector in the 4 countries show this large diversity: social housing ranges from $4 \%$ of the stock in Germany to $31 \%$ in the Netherlands. Also the degree of subsidisation and the arrangements to finance social housing differ widely. A social housing sector that is organised efficiently will not adversely influence the functioning of the PRS market too heavily. Inefficiencies in the system of social housing on the other hand can have negative effects on the PRS market. The problems related to split markets between rent setting in the social and private rental sector have already been discussed in the previous section: large differences in rent regulation between private and social rental markets can lead to lock-in effects in social housing for people with higher incomes, reduced accessibility for outsiders on the market, and also black markets and queues.

62. State subsidies and guarantees for social housing can lead to a crowding out of PRS investment, as there can be unbalanced competition between PRS and social housing (see also Oxley ea. 2010). Investments in social housing might crowd out investments by other actors on the market - especially if social housing is accessible for households that otherwise would have rented or bought on the private market, thus reducing private demand and supply (Andrews ea 2011, p. 46). The degree in which crowding out occurs differs widely across the cases and will therefore receive attention in this section.

63. This issue of competition between social and private landlords is most pronounced in the Netherlands, and is a central factor for the marginal position of the Dutch PRS. In Finland the competition between PRS and social housing is less pronounced, but there are some competition issues between municipal social housing and other not-for-profit-actors that supply social housing. Germany has minimised distortion of the social housing sector, due to the temporary nature of social housing subsidies and the small size of social housing. Here, the challenge is to provide social housing in those places where it is most needed. Also issues of oversight and governance of social housing will be discussed, as the Czech case shows important consequences of not having a strong regulatory framework for social housing. Finally, trade-offs of eligibility and means-testing for social housing will be discussed. 


\subsection{The dominance of social landlords on the Dutch housing market}

\section{Box 3. Housing associations in the Netherlands}

The position of housing associations is crucial to understanding the Dutch housing market. Housing associations are not-for-profit private actors with a dominant market position that provide social housing and own $77 \%$ of all rental dwellings in the Netherlands. They work within a public legal system, and are obliged to re-invest any surpluses in social housing and related fields (regulated in national decrees). Housing associations can invest in a broad field of activities, related to housing, the physical environment, and the 'livability' of neighborhoods.

There is a substantial system of state aid in place that safeguards the 'societal capital' of the housing associations; EUR 86 billion of loans of housing associations are part of this guarantee structure (2012). The risks are covered through the Social Housing Guarantee Fund (WSW) that guarantees loans for societal activities for the financiers: investments in regulated rental dwellings, social real estate, livability investments and investments in deprived neighborhoods. If a housing association would get into financial trouble there are three tiers in the guarantee system: the first is through the 'Central Housing Fund' CFV, a state organisation that oversees the financial operation of all housing associations. CFV can levy a tax that all housing associations have to pay to restore the financial stability of a housing association if it gets into trouble. The Social Housing Guarantee Fund serves as a second tier through a fund that is formed by payments of housing associations (currently EUR 500 million that can be enlarged to EUR 4 billion). As a last resort there is a state guarantee by national government and municipalities. The second and third tiers of this guarantee system have never been used. Because of the guarantee system housing associations can acquire below market rate loans: the interest rates are lowered by 0.5-1percentage points relative to AAA-rated private sector debtors without government guarantee. It is estimated that this constitutes an annual interest benefit of EUR 500-800 million (WSW 2013; Conijn 2011, p. 27).

64. Crowding out of private investors is an important problem of the Dutch social housing system, as there is no level playing field for private investors. Earlier OECD research concluded that the housing market in the Netherlands "is characterised by a large and rigid social housing sector" (OECD 2010, p. 10). Housing associations play an important role on the Dutch housing market, as they own almost $1 / 3$ of all dwellings in the Netherlands, and $77 \%$ of all rental dwellings. The housing associations are part of an extensive public system of regulation and state aid (Box 3). The Dutch system has definitely created positive results on the rental market: the rental sector is large in international comparison, has good quality and low spatial segregation - stigmatisation or residualisation are not visible on the Dutch market. The housing associations play an important countercyclical role on the housing market: because of state aid they can invest in times when housing production is low, and they are able to invest in neighbourhoods with weaker socio-economic status and as such have an important role in fighting spatial segregation.

65. However, the regulations and government support that are organised for housing associations have enabled these organisations to acquire a dominant market position ${ }^{6}$."In the Netherlands in particular, the social rented sector is much larger than the private and provides good quality accommodation for a wide range of households. Private renting would find it hard to compete and is mainly restricted to more mobile households and those excluded because of queues - in other words, the majority of prospective tenants consider it the less desirable option.” (University of Cambridge 2012, p. 77). The social landlords have large financial benefits that have crowded out other investors on the rental market, as private investors have to compete with these not-for-profit organisations (Høj 2011). The total capital of housing associations has risen considerably, due to the price increases on the housing market. There is no obligation for housing associations to make a yield based on their capital - and the average yield on their own capital is only $1 \%$. Current rules do not prevent housing associations to invest in unregulated rental

6. For a more extensive review on the dominant position of the housing associations on the Dutch housing market, see Kemeny ea. (2005). 
dwellings or owner-occupied housing - thereby further hampering private investment and possibly leading to misallocation of publicly guaranteed resources.

66. This absence of a level playing field has negative consequences for the PRS market and is an important factor in explaining the marginal position of the PRS on the Dutch market. Due to these financial benefits, housing associations can keep their rents at regulated levels, even if the quality of the dwelling is high -as in principle almost half of the dwellings by housing associations are of sufficient quality to be rented out at an unregulated price ${ }^{7}$. This situation undercuts demand significantly and structurally weakens the position of private landlords of unregulated dwellings, as the same quality is available from social landlords at a lower and regulated price. Therefore, the supply of unregulated private dwellings with a rent just above the liberalisation boundary of EUR 681 is relatively small. The dominance of regulated rental dwellings offered by housing associations also drives up the prices for unregulated PRS dwellings, as housing associations build new high quality social dwellings for which they ask rents that are lower than the actual building and management costs, providing a further barrier for supply by private investors. For new social dwellings the 'unprofitable gap' - the difference between expected future income from cost based rent setting and the actual costs for construction and maintenance - is estimated to amount to EUR 80000 per dwelling (RIGO 2011). Housing associations can finance this gap, because they can decide on the use of their capital - and they do not need to obtain yields on their capital.

\subsection{Competition between non-profit actors: Finland}

67. In Finland the tenure shares for social and private rental housing have been stable over the past years and in many regions the prices for private and social rental are close: there is apparently not a too large distortion of the market between these tenures, as regulation in the PRS is very liberal and the same tax rules generally apply to both social and private landlords. The social housing stock is owned for over $60 \%$ by municipalities and other public corporations. $17 \%$ is owned by other not-for-profit organisations and less than $20 \%$ is owned by student organizations and elderly organisations. There are national subsidies for social housing that are administered by the State Housing Development Fund ARA. A state guarantee on social housing leads to lower borrowing costs for social landlords in the form of an interest subsidy loan, however the total amount of the interest subsidy was EUR 20 million in 2011 and thus was not exceptionally large and does not lead to a large crowding out of private rental housing. A competition issue on the Finnish market concerns the differences between municipal social housing companies and other non-profit actors that offer social housing. Social housing landlords are obliged to invest 5-10\% of own capital to obtain subsidies for social housing through the Housing Development Fund ARA. Often municipalities give no-interest loans to their own municipal housing companies, whereas other non-profit actors have to obtain market loans, thereby creating differences between different non-profit suppliers. Therefore municipal companies can have a different strategy, which is driven less by market forces that nation-wide players like VVO and SATO - big institutional investors in the rental market that also rent out social housing. Municipal companies have a tendency to overlook the market circumstances, as they do not take location into account, which leads to artificially low rents in parts of the municipal stock.

\subsection{German social housing: a well-integrated sector}

68. The German social housing sector does not cause much distortion of the rental market - as the subsidies are temporary, and also because of the continuous decline of the size of the social rental market

7. In fact, recent analysis (CBS Huurenquute 2012) shows that there is hardly a relationship between the value of the rental dwelling and the price of social housing. It seems that the housing associations set their rents based on the price boundaries of the rent regulations and housing allowances: they keep the rents below the regulated level of EUR 681 or below the maximum limit for the housing allowance EUR 574. 
in the past 30 years. An interesting feature is the German system of temporary subsidies that returns social housing to the private market after the end of the subsidisation period (today typically about 10-15 years). During the subsidy period there are rules for the entry and rent increases that are part of the subsidy contract between the landlord and the local government. Crowding out of PRS investments is thus not a large problem on the market, also because social housing subsidies can be obtained by different types of actors - both public and private, profit and not-for-profit.

69. At first sight the number of 1.6 million social dwellings (3.9\% of the housing stock) seems low for a housing stock of more than 40 million units, and shortages are reported in tight housing markets. The relatively low share of social housing does not give a complete picture of the affordable housing stock in Germany, as in total $6 \%$ of the dwellings are in public hands and these public landlords often rent out at affordable levels, also after the subsidy period for social housing expires. The large rental stock was built up by extensive supply subsidisation since the Second World War: in total about 5.5 million social dwellings were subsidised. In the last 20 years social housing is in constant descent, as subsidies for social housing have been scaled back and have been decentralised to the state level with an additional financial compensation of EUR 520 million by the federal government until 2019. Each year far more social dwellings lose their social status than new subsidised social dwellings are constructed. Another factor that led to less social housing was that in previous years public housing stocks were sold to investors. This has led to critical public discussions, and large-scale privatisations are not expected for the future.

70. Stakeholders have different views on whether the decline of social housing in Germany is problematic. Tenant associations state that the low number of affordable housing is a problem. Especially as it is expected that demand for these houses with low rents will remain strong, because of an ageing population, and an increasing risk of old age poverty (OECD forthcoming). However, the Federal Ministry of Transport, Building and Urban Development pointed at the fact that this might not be a dramatic development, since these dwellings often remain accessible for people with lower incomes, after they lose their social status - as many landlords will not increase the rents for sitting tenants fast to avoid conflicts. Also there is still a public housing stock. Most experts conclude that in large parts of Germany there will not be large problems, but in areas where there is a concentration of people with lower incomes there is not enough supply.

71. A downside of the German system of temporary subsidies for social housing is that it requires continuous activity by government to retain the social housing stock. This subsidisation is completely the competence of the states, supported by a federal government subsidy. However, there are big differences between the states in the way they use the federal money: it can be used for owner-occupied housing, for energy efficiency measures and renovations in the existing stock and also to stimulate supply of social rental dwellings. The subsidisation does not only stimulate the addition of social housing supply, but also serves other goals related to the housing market. States as Hamburg, Bavaria and North Rhine-Westphalia have the most active policies for social housing and invest considerable sums of their own resources, whereas other states only use the federal money. A challenge for the German system is to target subsidies for social housing in such a way that the investments are where they are most needed.

\subsection{Governance and oversight of social housing: a complex situation in the Czech Republic}

72. Well-functioning oversight and governance of social landlords is important to ensure effective social housing policies. Social housing in the Czech Republic seems to suffer from 'underregulation', as mass privatisation of the municipal housing stock and a lacking national framework are central concerns for many actors and are important inefficiencies on the Czech housing market. As the country report shows there is no legal definition of social housing, nor is there legislation in place for not-for-profit housing or housing associations. The share of public housing decreased substantially from 39\% in 1991 to 8-9\% of total housing stock in 2011. This decrease was mainly due to large scale privatisations to sitting tenants, 
often at prices far below the market value. Central government did not introduce social housing legislation or a long-term social housing strategy; and the level of new construction of subsidised social housing construction is marginal. Since 2002 only about 20 thousand units (about $1 / 2$ per cent of the total housing stock) were made available solely for households with low incomes or other problems. As there are not many special rules for public housing in the Czech Republic it can even be questioned whether public housing is 'social' in nature, as there is no regulatory framework for the use of the public housing stock, and municipalities have nearly complete freedom to manage the housing stock (Lux \& Sunega 2013). This use of the public stock is also due to a complex local governance situation (Box 4).

\section{Box 4. Local governance and privatisation of public housing in Prague}

An important process that can be witnessed on the Czech housing market over the past 20 years is the selling of public housing to the sitting tenants - often at a value far below the market prices (as low as 5 to $10 \%$ of the actual value). Municipalities are exclusive owners of public housing and due to strong decentralization of power municipalities are free to have their own local social housing policies and can set their own rental policies. In some cases municipalities act in the same way as private landlords, as they want to maximise profits from their housing stock. After the fall of Communism the whole public housing stock was transferred to municipalities, without conditions for use. Until rent deregulation, strict rent control and strong tenure security prevented municipalities from introducing an effective way of managing the social housing stock. The municipalities were losing money and there was thus an economic incentive to sell the properties, as they were obliged to pay the housing subsidies from their own budget. In some extreme cases the municipalities privatised their complete stock. This 'privatisation' is a socially accepted practice, and consumers are used to the huge benefits that are given to sitting tenants that are given the possibility to buy the flat. Despite rent deregulation, the municipalities continue to privatise public housing to tenants under giveaway conditions. This leads to a 'privatisation trap' (Lux \& Sunega 2014): municipalities were unable to limit the process of privatisation because of raised expectations. The privatisation is the single largest housing subsidy, although it is not visible in official statistics.

An example of the mass privatisation of public housing is the municipality of Prague 2, located in the centre of Prague. In $1989100 \%$ of the flats were state property, but $70 \%$ of the stock changed ownership to former owners through restitution. $30 \%$ of the stock was kept as municipal housing by Prague 2 , and a separate municipal housing association was created. There was a strong tendency to see state ownership as negative and the municipality of Prague 2 sold half of its stock for prices far below the market prices: today the share of public housing is $16 \%$. There is still a strong push for privatisation: there is even a political party of public tenants in the municipality that pushes an agenda of selling public housing to sitting tenants at low prices. The current coalition in Prague 2 has agreed to change the situation of social housing. There is a goal to sell half of the stock, but no longer at giveaway prices. The market price has become the basis for privatisation: tenants get the option to buy the dwelling at 70 or $80 \%$ of the market value, but they have to keep living in the flat for 10 years.

Also the governance situation is complex in the Czech Republic. There are more than 6000 municipalities, and the City of Prague is divided in $\mathbf{5 7}$ smaller municipalities. It has to be understood from the history after the fall of Communism. There was an important goal to decentralise government - to move away as far as possible from the extremely centralist government during Communism. However, the problems with social housing can be exacerbated and decision-making becomes too localised: as municipalities are very small, they will often not have effective means to manage the public housing stock. Also, if one small municipality invests in public housing, it is afraid that it will draw problems from the neighbouring municipalities.

73. The core of the problem in the Czech Republic is the lack of a national social housing framework that leads to problems of governance and oversight. There have been discussions underway to introduce social housing law on a national level, but they were unsuccessful. Many actors would welcome better national regulation on public housing, for instance by introducing clear obligations for municipalities to take care of the poorest people. Also the continuing process of privatisation of public housing is inefficient: dwellings that are sold under the market level entail giving benefits to individual citizens, instead of using the capital in the public interest, as it is public property. The declining number of social housing also runs the risks of creating social problems in some neighbourhoods, as it reduces policy options for municipalities. There is however strong opposition from the municipalities, to new national laws on social housing. 
74. Also in Finland oversight of social landlords was not completely effective. According to the law, municipalities are responsible for monitoring tenant selection and rent setting. The country report shows that municipalities often have very limited means to execute efficient monitoring. One of the reasons is that large not-for-profit owners typically equalize maintenance and capital costs across different buildings. If this equalization happens across municipality borders, monitoring of the true cost structure becomes very difficult for the municipalities. The actors on the market indicated in general there is a view that municipal oversight seemed to exist more on paper than in reality. Therefore central government is taking measures to improve oversight of the social housing sector - and oversight will be centralised in the State Housing Development Fund ARA. A point of criticism that is also mentioned is that landlords and experts noted that the rules are fragmented and sometimes open for interpretation - for instance on the rules for the costs of social housing, as currently there are quite large municipal differences.

\subsection{Eligibility for social housing}

75. Another important aspect of the competition between social and private housing concerns the entry into social housing and means-testing for sitting tenants. Such measures seek to target the social sector to those people who need it most. However several trade-offs can be witnessed with targeting of social housing. For instance, if eligibility for social housing is wide, this will lead to a high cost for public finances and less demand for PRS renting. In combination with strict rent regulations broad eligibility and the absence of means-testing can lead to problems with accessibility of social housing, as there is a wide demand. As earlier OECD research noted: "One potential advantage of a targeted system which uses greater prioritisation through narrower eligibility criteria is that it can in principle focus on households in greatest need of housing and therefore achieve its goals at a lower cost and entail less deadweight losses than less targeted social housing systems.” (Andrews ea. 2011, p. 45). On the other hand: if narrow eligibility criteria and strong means-testing are applied, there are risks of a more residual social rental sector, in which people with the lowest incomes live, potentially leading to more segregation of the population. There is thus a trade-off in the targeting of social housing and residential segregation: "there would seem to be a potential trade-off between allocating social rented housing on the basis of need and preventing concentrations of socio-economic disadvantaged groups at the neighbourhood level. Meanstested social housing systems may also potentially reduce job-seeking incentives amongst the unemployed or discourage low-wage workers from seeking higher paid jobs if reassessment of eligibility takes place and social housing is withdrawn or rents increased as earned income increases.” (Andrews ea 2011, p. 46)

76. In the Netherlands there were no national rules on eligibility for social housing, until in 2011 an eligibility criterion for social housing was introduced: $90 \%$ of new leases of regulated dwellings owned by housing associations have to be assigned to people with an income of maximum EUR 34 220, and there are long waiting lists for entry, and the time spent on the waiting list is important in deciding on the entry into the social sector. This still means that eligibility is broad, as it concerns the lowest $40 \%$ of incomes. After entry in social housing there is no means-testing, except for higher maximum rents for higher incomes. Tenant's associations and the housing associations have opposed the measure, as it is considered not differentiated enough, as an unregulated rent above EUR 680 was not affordable for people just above the eligible income. Also it was considered important to have a broad-based sector to fight income segregation and to invest contrary to the market in neighbourhoods with a weaker social profile. The Dutch parliament has recently requested the Dutch government to broaden the scope of social housing again by increasing the income limit. Experts on the other hand agree an income limit for entry in social housing by housing associations is beneficial, as it sets a clearer target group for the social sector, promotes accessibility of social housing for people with lower incomes and thus reduces competition with the PRS. The eligibility rules have led to increased demand from middle incomes for PRS and owner-occupied housing, especially by newcomers on the market. A side effect is an even stronger lock-in in regulated housing for sitting tenants with higher incomes, since they are no longer eligible for social housing. 
77. In Finland the allocation of social dwellings is regulated and dwellings are distributed according to need, income and wealth - but broad sectors of the population are eligible (about 70\%). A benefit over the Dutch system is that priority in entry is weighted according to need, income and wealth and not according to the number of years on waiting lists. The aim of the tenant selection is to guarantee that the dwellings are attributed to households who most need the dwelling while at the same time aiming for a diverse tenant structure within the building and a socially balanced neighbourhood. There is no means testing for sitting tenants, which also leads to people with higher incomes living in social housing. In 2005, $42 \%$ of all households in the social rental housing belonged to the lowest income quintile and $7 \%$ to the highest income quintile. And mobility rates are significantly lower in social housing. Discussions on using the social housing stock more efficiently, for instance by introducing means testing, have not led to measures, as it is considered to lead to increasing segregation within the country and especially in Helsinki. Nevertheless, landlords and experts mention that defining a clear target group, and introducing meanstesting for higher-income tenants, and more flexibility in local plans for newly built social housing could improve the functioning of the market and increase PRS supply.

78. Germany also has eligibility criteria for social housing - that are substantially lower than in the Netherlands and Finland: the income limits are: EUR 12000 for a single person household, and EUR 18000 for a two-person household. Additional persons increase it with EUR 4100 for adults and EUR 4600 for children. State governments can deviate from these rules to reflect the local economic circumstances. The lock in effects might be limited, given the temporary status of social housing. Germany also has experience with means-testing for social housing after entry, but these experiences were not very successful: there were measures to increase rents in social housing for tenants with higher incomes. However, these measures have been reduced in many states: a probable explanation is that the social sector is relatively small so that these targeted measures had a high administrative cost relative to the benefits. In the Czech Republic the municipalities have the freedom to decide their own rental policies, so there are no national rules on eligibility or means-testing - except for the small number of subsidised newly constructed social housing. Especially in the past, a large part of public housing was occupied by relatively well-off households that did not need any special rental discount (Lux et al. 2009).

\subsection{Findings: less distortive and more efficient social housing policies}

79. Social housing affects the functioning of the PRS in many ways in the 4 countries. It is important to realise that competition between social and private rental sector cannot be completely avoided. The PRS is affected heavily by competition of social landlords in the Netherlands. Here the legal and financial position of associations is so strong that the PRS cannot compete. It has also led to good results in the Netherlands: there is a large rental sector, and the housing associations have the possibility to invest in weaker neighbourhoods and to fight segregation. However, it can be asked if the housing associations need such a dominant position to achieve these goals. It will be essential for the future prospects of the private rental market to focus the social landlords on their core tasks - providing affordable housing. There should be clear legal boundaries between social investments of housing associations and commercial activities. Currently an overhaul of the regulations for housing associations is underway, as the Dutch government wants to clarify and reduce the tasks of housing associations to their core business of providing affordable housing for lower income households.

80. A further improvement toward a level playing field in the Netherlands could result from targeting the regulated part of the market better: all rents up to EUR 681 are regulated and this comprises 93\% of the rental market. For all social dwellings with a rent up to this level owned by housing associations the regulations and state guarantee applies. It can be questioned whether it is necessary to regulate all these rents. Experts and investors agree that a rent of EUR 680 cannot be afforded by people with lower incomes. It is therefore beneficial to decrease the size of the regulated sector of the market, for instance by 
lowering the maximum regulated rent to the maximum level for the housing allowance (EUR 574). This can stimulate commercial investments in the segment above this boundary.

81. The Finnish social housing system shows less distortion between the PRS and social housing sector, and also the importance of the supply subsidies have been reduced in the past years. The targeting of the social subsidies is aimed at stimulating housing production, and not on other issues related to housing. The Finnish case shows problems with the municipal oversight over social housing. The centralisation of oversight as is now proposed by the Ministry of the Environment is welcome, and also gains could be made by streamlining and clarifying the rules for the social housing sector. The State Housing Development Fund ARA could for instance develop benchmarking for social housing costs so that municipalities and private non-profit actors can improve the effectiveness of state subsidies for social housing. Investigating such measures could be part of the review of the effectiveness of housing subsidies that is undertaken in 2014 in preparation for the next Finnish government.

82. The German system does not hinder competition between PRS and social housing, because of the temporary status of social housing. However, it requires constant subsidisation to keep the social housing stock at the same level. The German government should consider a better spatial targeting of subsidies. This would ensure that subsidies are used more efficiently by directing them at places where they are most needed. Although it may be hard to implement due to the federal structure of the German state, where competences are delegated to the state level. It could be worthwhile for the federal government to set up a monitoring and benchmark system for housing needs and housing supply, so that it is clear where most investment is needed.

83. The negative consequences of lacking regulation of social housing can be witnessed in the Czech Republic: there are no clear goals for social housing, and large scale privatisations at below market level have taken place, as there is complete municipal freedom to decide on issues of public housing. This has led to inefficient use of the public stock. These are urgent issues that should be addressed. The Czech Republic should consider implementing national guidelines on social housing, so that the tasks for municipalities are delineated: municipalities should use the public housing stock in such a way that those most in need receive support. Privatisation of public housing at values far below the market level should be prevented.

84. The discussion on eligibility for social housing has shown that there are inefficiencies in the Netherlands and Finland. The introduction of an eligibility criterion in the Netherlands led to better accessibility of social housing for people with lower incomes. Finland could also improve the functioning of social housing by defining a clear target group. Given the relatively large stock of social housing in both Finland and the Netherlands, strong segregation effects are not to be expected from introducing measures to target the social housing sector better. Using the social housing stock more efficiently could actually increase accessibility for households with the lowest incomes by stimulating turnover rates and thereby reducing the insider-outsider problems.

\section{Fiscal treatment of the rental sector}

85. Tax measures should aim at promoting tenure neutrality Most countries use some form of tax breaks to make rental housing attractive for investors, for instance by lowering taxes on rental income relative to other forms of income or capital, or by enabling deductibility for mortgage payments or other costs, by allowing depreciation of dwellings or off-setting of losses in rental income against other forms of income ('negative gearing') (see Scanlon \& Kochan 2011 pp. 25-27 and UIPI 2013 pp. 36-40 for a broad international overview). An important factor is also how these tax relief measures compare to tax relief for home owners, as will be discussed in section 8. 
Table 5. Fiscal treatment of rental income

\begin{tabular}{|c|c|c|c|c|}
\hline \multirow[t]{2}{*}{ Country } & \multirow[t]{2}{*}{ Tax base } & \multicolumn{2}{|c|}{ Tax rate } & \multirow[t]{2}{*}{ Deductibles } \\
\hline & & Personal & Corporate & \\
\hline DEU & Rental income & $14-45 \%$ & $15 \%$ & $\begin{array}{l}\text { Mortgage and loans interest, } \\
\text { donations, depreciation. }\end{array}$ \\
\hline CZE & Whole income & $15 \%$ & $19 \%$ & $\begin{array}{l}\text { Maintenance and repairs. } \\
\text { Depreciation. }\end{array}$ \\
\hline FIN & Rental income & $30-32 \%$ & $24.5 \%$ & $\begin{array}{l}\text { Maintenance, renovation and interest } \\
\text { (provided it came from a loan used to } \\
\text { acquire income) are deductible }\end{array}$ \\
\hline NLD & $\begin{array}{l}\text { Whole income } \\
\text { (non-professional } \\
\text { landlords) and/or } \\
\text { net capital value } \\
\text { (professional } \\
\text { landlords) }\end{array}$ & $\begin{array}{l}\text { Non-professional: } \\
\text { rental income is } \\
\text { added to whole } \\
\text { income and taxed at } \\
\text { marginal tax rates } \\
\text { (33 to } 52 \%) ; \\
\text { Professional } \\
\text { landlords: } 1,2 \% \text { on } \\
\text { net capital value }\end{array}$ & $20-25 \%$ & $\begin{array}{l}\text { For professional landlords: Interest } \\
\text { expenses on loans from banks or } \\
\text { affiliated companies, and property- } \\
\text { related costs }\end{array}$ \\
\hline
\end{tabular}

Source: Country reports, UIPI 2013

86. Countries often make a distinction in tax treatment between renting by private persons and by corporations (Table 5). For instance in the Netherlands rental income is not considered income for taxes for private persons. However, the personal capital on the other hand is taxed: there is a $1.2 \%$ tax on the value of all capital, with an exemption of EUR 21139 per person. In Finland the rental income and capital gains of private landlords are taxed according to the general capital income tax rate (below EUR 50000 is 30\%, above this a 32\% tax rate applies). Taxation in Finland is based on net income so landlords are allowed to deduct expenses, such as loan interests and maintenance costs, from their gross rental income before taxation. Corporations are also subject to a $24.5 \%$ corporate income tax.

87. As rental dwellings are seen as an investment there are often diverse possibilities to deduct related costs. In Germany landlords are eligible for mortgage interest tax relief and may offset losses from rental property against their other sources of taxable income ("negative gearing"). Owner-occupied housing is treated as a consumption good and does not receive these benefits; therefore the tax treatment facilitates using dwellings as an investment. And the even more generous tax treatment in the past is one of the reasons why small private landlords have become so important investors on the German rental market. Measures such as decreasing balance depreciation, directly-deductible maintenance costs and negative gearing in combination with tax-free capital gains "were especially attractive for well-off private investors with a high personal tax rate”, as Kofner argues. Since 2006 the degressive depreciation has been reformed, as there was no more general housing shortage in Germany. Since then income tax depreciation is linear at 2 to $2.5 \%$, and is consistent with economic depreciation.

88. The Czech Republic also uses generous depreciation as a means to stimulate supply in the rental sector. The tax provisions mean that landlords are entitled to discount depreciation from rental income (mostly for the period of 30 years). As Lux states: "This is an important tax incentive because annual depreciation may be almost as high as annual rental income when depreciation is applied or it can, at least, substantially decrease the tax duty of a landlord.” 
89. A further stimulating role of taxes for rental dwellings is the possibilities for modernisation, as seen in Germany. Landlords in Germany are entitled to increase the annual rent with a maximum of $11 \%$ of the total modernisation costs, when they renovate the dwelling. This measure supports investment in the rental stock and in maintaining and improving the quality of the rental stock. Kofner concludes that it is "a central instrument for keeping the housing stock in good condition with respect to contemporary technical standards"8, and especially for adapting the housing stock by taking energy-efficiency measures and adapting it for an ageing population. A side-effect of this measure is that it is an alternative to rent-setting based on the local reference rent, and thus enables higher rent increases. The German government intends to lower the modernisation benefit (from 11\% to 10\%) for landlords - this in itself should not provide a large barrier for the market, as the benefit is generous. However, the coalition agreement stated that an additional proposed provision is that the rent will have to be lowered after all modernisation costs are 'amortised' (Koalitionsvertrag 2013). If this provision is implemented, rents should be lowered to the previous level once the modernisation is amortised. This goes against market logic and can be a disincentive for investments in the rental stock, as it actually undercuts one of the measures that is important in maintaining the high quality and diversification of the German rental stock.

90. Most countries do not witness large differences in tax status between social and private landlords, as they are generally treated in the same way in Germany, the Czech Republic and Finland. In the Netherlands there used to be a difference in tax treatment between social and private landlords, as housing associations were tax exempted from the $25 \%$ corporate tax. From 2008 this exemption was terminated and housing associations pay full corporate taxes (Haffner ea. 2009, p. 226). This measure was taken to improve the level playing field with other investors.

\section{Box 5. The introduction of a tax for landlords in the Netherlands}

Tax measures can also have negative impact on the functioning of the housing market. In the Netherlands a tax for landlords who own more than 10 regulated dwellings was introduced in 2013. In order to offset the higher rent increases for regulated dwellings, and make a contribution to reducing the budgetary deficit, in the Netherlands central government levies a tax on all landlords with more than 10 dwellings (revenue EUR 1.7 billion per year in 2017, on the basis of the value of the dwelling, as estimated for the local property tax). This tax only applies for regulated dwellings. The tax puts important pressure on yields of landlords, as the tax equals the value of $1 \frac{1}{2}$ months of rent. The introduction of this tax has been received very critically by landlords, tenants and experts (Priemus 2014). It is considered a strong disincentive for investment in regulated rental dwellings - in the past years the investments of housing associations in new dwellings have been lowered, thereby reducing the important stabilising role housing associations have by investing counter-cyclically. It is also a barrier for the functioning of the PRS market, as $70 \%$ of privately owned dwellings are currently regulated. As the tax is only levied on regulated housing, it will be an incentive for landlords to increase the rents to unregulated levels. The foreseen evaluation of the landlord tax in 2016 should also cover its impact on the PRS.

\section{The growing importance of housing allowances}

91. In many European countries housing allowances are becoming a more important instrument of the housing system (Griggs \& Kemp 2012). The goal is to maintain the affordability of housing through direct subsidies to tenants; this shift can also be seen as a development to off-set the reductions of direct supply subsidies for social housing - these developments can be witnessed in all four cases. Also housing

8. See the German country report for a more in-depth review of the importance of the modernisation tax benefit.

9. This development was very marked in the UK, where demand subsidies accounted for less than $20 \%$ as compared to supply subsidies in the 1970 s to over $90 \%$ today (Stephens \& Whitehead 2013, p. 17). 
allowances have enabled the rent deregulations that were witnessed in many European countries, as Turner and Elsinga show: "the introduction of housing allowances also enabled the state to relax the rather stringent post-war rent controls in the private rented sector without jeopardizing housing provision and affordability for low income households facing rent increases. They were seen as a cost-efficient tool that permitted rents to rise, thus helping to keep the market efficient.” (Turner \& Elsinga 2005, p. 104)

92. As such, housing allowances can thus play a very important role for the functioning of the market: affordable housing can be delivered irrespective of the owner, and also through the private market - as allowances are generally applied in PRS and social housing alike in all 4 countries. Especially in Germany and in the Czech Republic this picture is clearly visible, as the social housing sectors are relatively small, and supply subsidies are low. The housing allowances guarantee affordable and accessible housing, also in the PRS market. Also three of the four countries have introduced tenure neutral allowances - Finland, Germany and the Czech Republic. The Netherlands is the country that has a 'rent allowance', which applies only for tenants. Here, it has to be kept in mind that the extensive subsidisation of the owneroccupied sector in the Netherlands is also very important for owners with lower incomes.

93. These broad-based allowances are quite comparable in the different countries. In Finland $17 \%$ of the total households receive housing allowance - and 53\% of tenants. A rent allowance is available in the Netherlands for lower income households in regulated rental dwellings: the allowance is based on income, age, family situation and the actual rent that is paid. In the Netherlands $15 \%$ of the population receives the rent allowance, or $34 \%$ of all tenants. Also Germany has an extensive system of subject subsidisation in place that guarantees that the housing costs can be paid. The German state pays housing benefits (Wohngeld), but this targeted at a relatively small section of the population (3\% of households, or 5\% of tenants). A more significant benefit is the housing costs component of social assistance for the unemployed. If both types of allowances are considered, $20 \%$ of all tenants receive either of these subsidies. In the Czech Republic the amount of households receiving the subsidy is lower, at about $4 \%$ of all households. The country report shows that the risks connected with rent arrears among low-income households can also be effectively managed by a relatively generous benefit system in the Czech Republic. Tenants in the Czech Republic are entitled to the housing allowance if 30\% (in Prague 35\%) of family income is insufficient to cover housing costs. For people in material need that have very low or no income there is a separate allowance ('supplement for housing') to ensure a minimum living standard after the payment of housing costs: the housing allowance together with the supplement for housing may actually cover total housing costs.

94. The clearest benefit for the functioning of the housing market is that the state allowances make the yields in the rental sector more secure. Generally tenants pay the rent, and if they cannot afford to pay the rent then the state subsidises an important part of the housing costs. Landlords, tenants and governments in all 4 countries mention the importance of supporting households with low incomes on the housing markets. And the broad-based systems that are in place in the 4 countries perform important roles on the housing market, as they enable accessible and affordable housing for people with lower incomes.

95. An interesting learning point is that several systems make regional differentiations. In Germany the income and rent ceilings of the allowance system depend not only on household size, but also on the local rent level - thus enabling a differentiated approach for different parts of the country. Finland has also differentiated the housing allowance levels according to regional differences in the housing market. This in contrast to the Netherlands where there is a unitary system in place that is applied to the whole country, and does not differentiate between different housing market regions. This situation in the Netherlands can have disadvantages, as in a situation of low supply elasticity it tends to drive up prices, whereas the rent allowance might be too low in tight housing markets. 
96. It is also important to mention that there can be disadvantages of income allowances for housing. They can drive up the prices of rental housing, as landlords may raise the rents to what the tenants can pay, and consumers are incentivised to maximise their consumption to the maximum that is subsidised. For instance in the Netherlands, it can be seen that many landlords will keep the rents just below the maximum level of the housing allowance. Tight rental markets will also encourage a capitalisation of allowances into rents - and this capitalisation is stronger if the allowance is based on the actual rent that is paid - as is the case in most countries. As André and Garcia advised for the Finnish housing allowance, there are disadvantages, as housing allowances based on the actual rent increase "the likelihood that a share of the allowance is capitalised into rents (...) Linking the allowance to the median rent in a specified geographical area could limit its capitalisation into rents. It would also address the problem created by social rents exceeding the housing allowance ceiling in some cases, mainly in the Helsinki region.” (André \& Garcia 2012, pp. 15-16). In general a tenure-neutral housing allowance can be important to reduce the differences between the subsidisation of different tenures. The targeting of housing allowances can be improved by implementing regional differentiation and distortion of rent prices can be reduced by coupling the housing allowance to average rents, instead of the actual rent that is paid.

\section{The effects of stimulating home-ownership}

97. The policies for the owner-occupied sector have an important impact on the functioning of the PRS. Stimulation of the owner-occupied sector relative to rental housing decreases demand for social and private rental. Despite growing evidence that stimulation of owner-occupied housing can have adverse effects for the economy and labour market, it is still common practice in many OECD countries to fiscally subsidise home ownership - and in many instances lead to a housing policy system that is non-neutral towards tenures (André 2010). The most common policy instruments are mortgage interest tax deductibility, imputed rents that are untaxed and exemptions from capital gain taxes. In many countries, property taxes are relatively low (André 2010, pp. 29-32). Figure 9 also shows that there is a relationship between the household mortgage debt and the size of the PRS, although there are considerable differences between countries. 
Figure 9. PRS size decreases with higher household mortgage debt

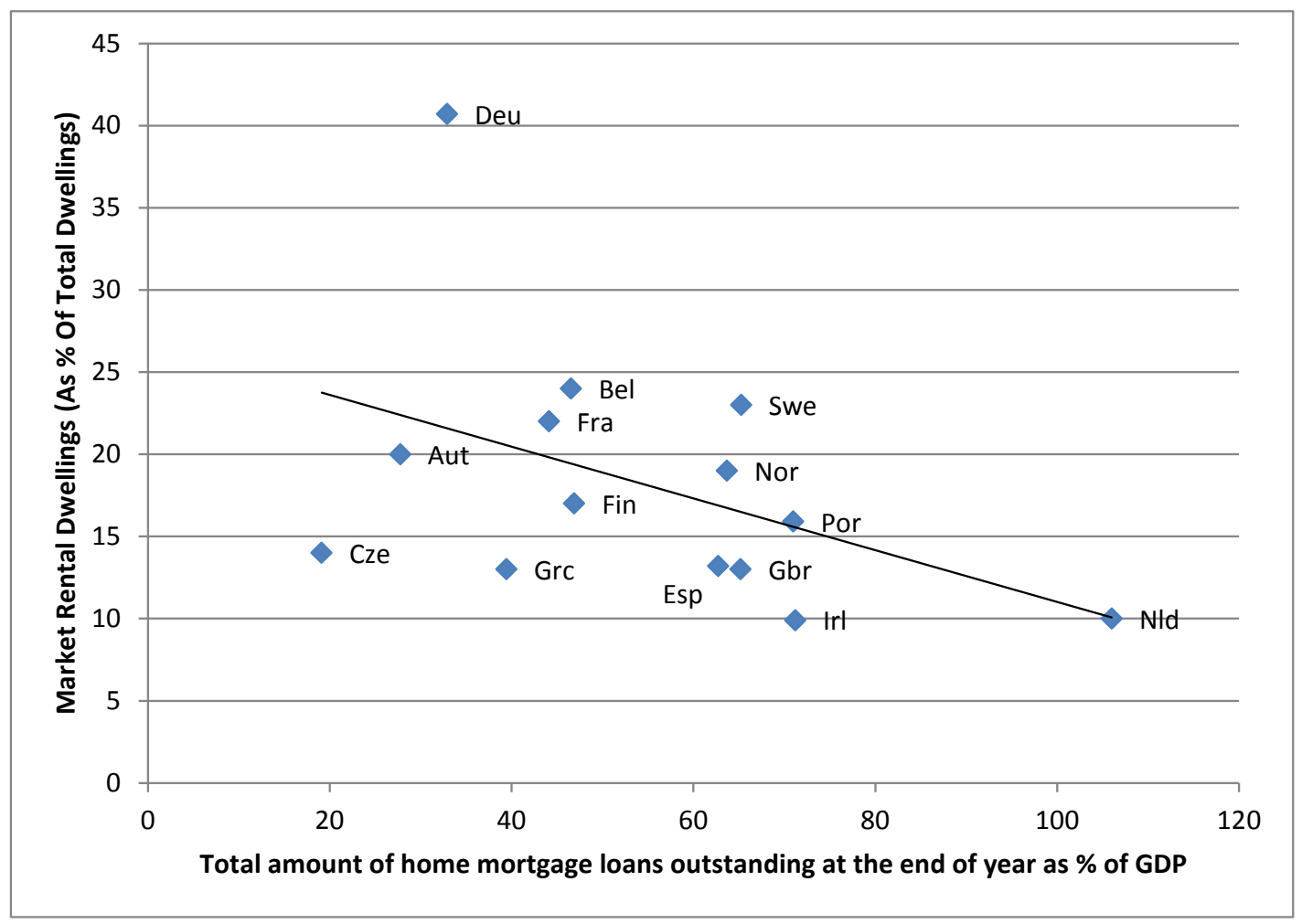

Source: Andrews et al., 2011, National statistical offices, Eurostat, Housing Finance Information Network

98. André reviewed the most important developments on the owner-occupied markets in OECD countries: "Over the past decade, the world has experienced an unprecedented house price boom in terms of magnitude and duration (...). Low interest rates and mortgage market innovations fuelled housing demand and mortgage equity withdrawal boosted private consumption in a number of economies, in particular in English-speaking countries.” (André 2010, p. 5). As a consequence of increases in house prices, and facilitated by access to mortgage credit most OECD countries have witnessed "a dramatic increase in the level of household debt" - going at an unprecedented pace from an OECD average of 100\% of disposable income in 1995 to almost 170\% in 2007 (André 2010, p. 22). Recent evidence suggests that this trend of fast debt growth has halted or in some cases reversed since the economic crisis, as debt levels have remained largely constant or decreased slightly in most OECD countries, thus reflecting decreasing house prices in many OECD countries and less generous access to mortgage credit; the main exception to this trend is the Netherlands, where debt levels continued to increase since 2007 (Figure 10). ${ }^{10}$

10. See also European Commission (2014) for a recent overview of developments in the mortgage and housing markets in the European Union. 
Figure 10. Development of household debt in OECD countries

Debt of households and non-profit institutions serving households, as a percentage of gross disposable income

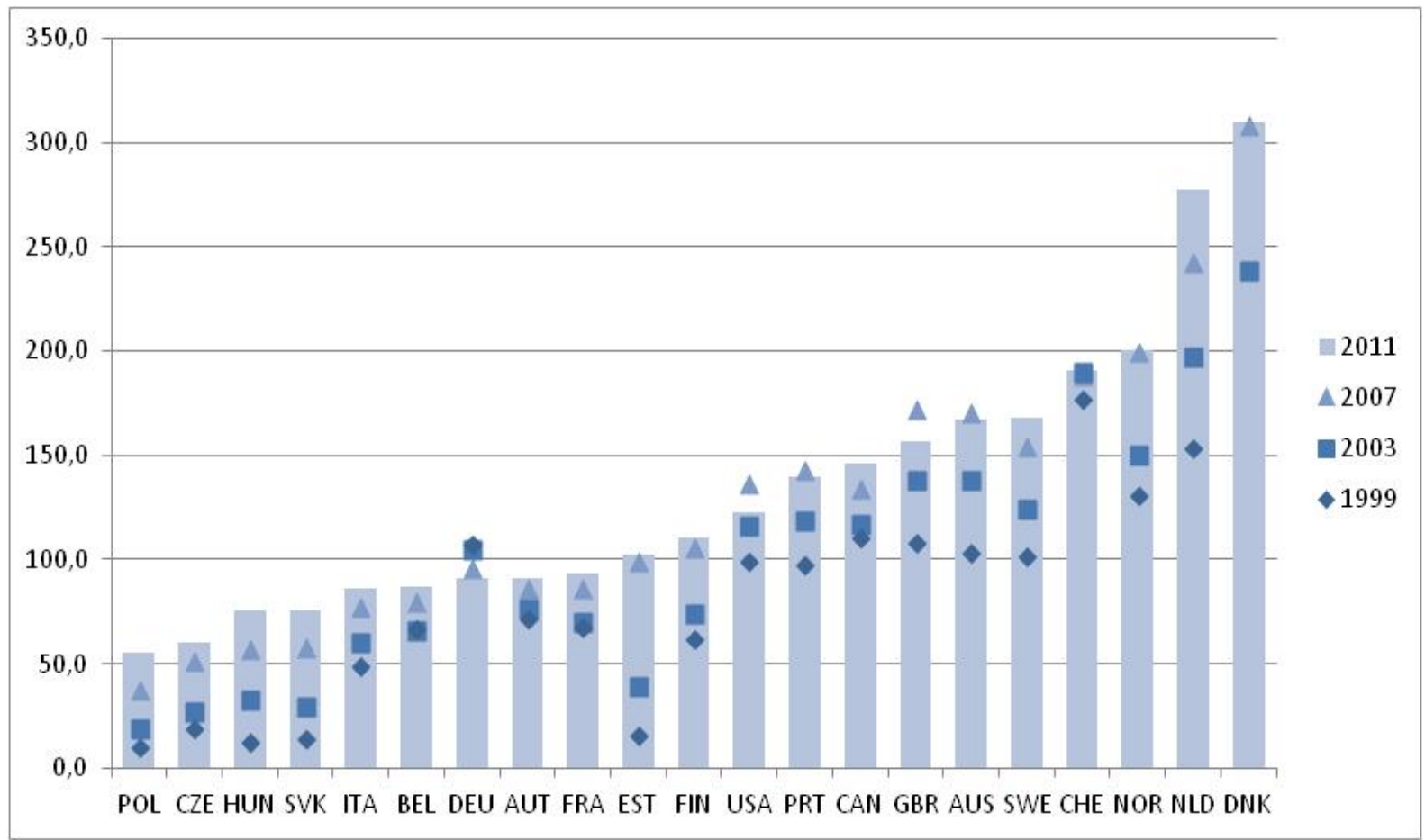

Source: OECD Factbook 2012

99. The effectiveness and economic benefits of stimulating home-ownership have been questioned. André (2010, pp. 33-34) presents some of the negative consequences. Fiscal stimulation can lead to overinvestments in housing, decreased labour market mobility, a pushing up of real estate prices, and increased price volatility in the market. Mortgage interest tax deductibility stimulates households to have and maintain high LTVs, thereby reinforcing risks for residual mortgage debts. André contends that a wellfunctioning rental market can decrease such volatility. High household debt also exposes consumers, banks and governments to risks in the housing market and to sudden changes in interest rates. ${ }^{11}$ Figure 11 shows the significance of the mortgage interest deductibility across countries - again pointing at the large subsidisation of home-ownership in the Netherlands. The recent reforms in the Czech Republic have lowered the tax wedge considerably. In Germany the wedge is zero.

11. See Scanlon \& Elsinga (2013) for a sobering picture on the effects of the financial crisis on the owneroccupied markets in the UK and the Netherlands. 
Figure 11. Large differences in tax relief on debt financing of home-ownership, 2009

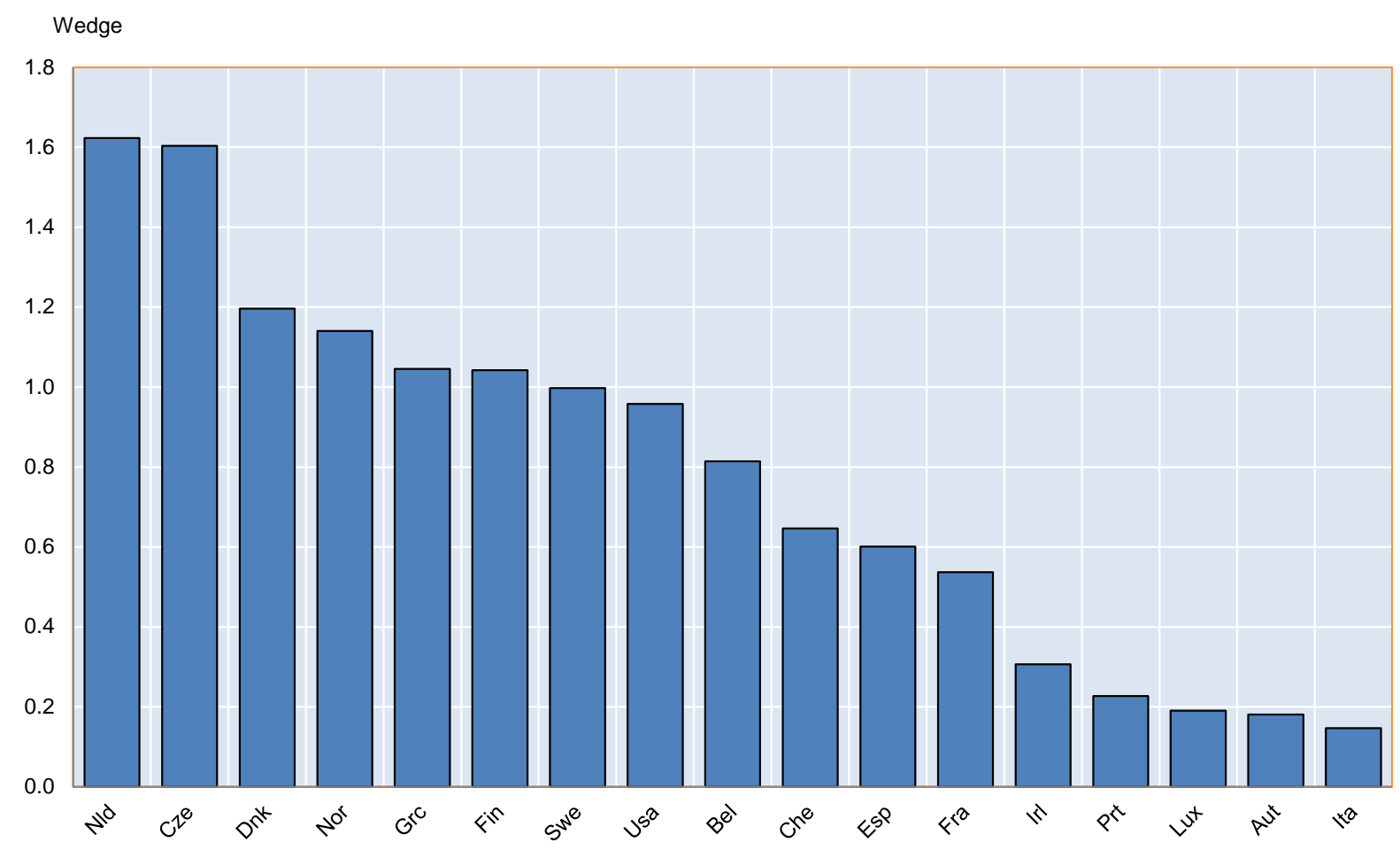

1. This indicator takes into account if interest payments on mortgage debt are deductible from taxable income and if there are any limits on the allowed period of deduction or the deductible amount, and if tax credits for loans are available. For countries that have no tax relief on debt financing costs, this indicator takes the value of zero.

Source: Andrews et al, 2013 based on OECD Housing Market questionnaire.

100. Recent studies underscore several negative economic and labour market effects of a high homeownership rate. In their study on home-ownership and labour market effects in the US Blanchflower and Oswald find that "high home-ownership in a US state is associated with lower labour mobility, longer commutes, and fewer new firms and establishments" (Blanchflower \& Oswald 2013, p. 13). This pattern is in line with what Van Leuvensteijn \& Koning found in their study on the Dutch housing market. Employed home-owners are less likely to move than renters and are less likely to accept another job. The authors find that owners are more committed to their jobs and less prone to unemployment (Van Leuvensteijn \& Koning 2000, pp. 16-17). Laamanen shows in his study on Finland that there are two simultaneous developments: a positive individual effect on labour participation of home-owners, but adverse effects for the wider economy: "while home-owners are less likely to experience unemployment, significant externalities counteract the positive effects of home-ownership at the aggregate geographical level. The external effects may be due to consumption reductions and increased local job competition caused by home purchases, especially if the purchases are financed by debt.” (Laamanen 2013, p. 24) This might indicate that increasing home-ownership can push household prices and debt levels up.

101. The evidence from the case studies corroborates the possible negative effects of stimulating home-ownership on the PRS. The Netherlands has the strongest fiscal sponsorship of the owner-occupied sector and the smallest private rental sector - also negative effects of high house prices and high debts can be witnessed here. In Finland fiscal sponsoring of home-ownership was reduced and the PRS has experienced growth, although home-ownership remains tax favoured. The Czech Republic in the economic transition had to 'create' markets for owner-occupied housing and mortgages, and also used fiscal 
subsidies to sponsor home-ownership. Recently, the Czech Republic is taking measures to improve tenureneutrality. Germany's policies are largely tenure-neutral, and the home-ownership rate is low compared to other OECD countries. Germany's housing market was largely unaffected by the global financial and economic crisis that has led to strong decreases in prices and transactions in many other countries - the stable tenure division and the lack of strong sponsoring of home-ownership have contributed to the 'resilience' of the German market (Kofner 2013; Voigtländer 2013).

\subsection{The risks of strong subsidisation of home-ownership}

102. Fiscal stimulation is the most pronounced in the Netherlands and an important factor in reducing demand for the private rental sector. Extensive fiscal sponsoring of the owner-occupied sector and increasing options for financing by financial deregulation have led to a strong stimulation of demand. For middle and high-income households the push towards the owner-occupied sector is particularly strong, given the regressive nature of the mortgage interest deductibility: deductibility increases with income to a maximum of 52\%, and on average housing costs are lowered by $40 \%$. During the 1980 s and 1990 s financial and mortgage markets were deregulated and mortgage lending rules where loosened, for instance by enabling loans based on 2 incomes, higher LTVs (above 100) and more possibilities for individual assessments by banks. Mortgage providers also developed innovative mortgage products that maximise fiscal benefits, such as products with (partially or totally) no amortisation of debt or saving schemes. Taxes on imputed rents and local property taxes are low when compared to the fiscal benefits, residential capital is exempted from capital tax and capital gains are untaxed. Prices rose fast during the 90s and early 2000s due to the combination of fiscal sponsoring, economic growth, and increasing possibilities for mortgage financing and innovative mortgage products. There are risks involved for consumers, banks and government of this high share of debt-driven owner-occupied housing. The financial crisis has also shown some of these risks, as prices for owner-occupied housing are currently 30\% below the peak of 2008 in real terms and the number of transactions is $40 \%$ below pre-crisis levels.

103. The effect was a steep increase in mortgage debts - the residential mortgage debt currently stands at EUR 670 billion, or $111 \%$ of GDP, the second highest of all OECD countries. There is thus a concentration of equity in the owner-occupied sector, which exposes both households and banks to changes in the housing market situation. Due to the extensive subsidies for home-ownership the Dutch government is also exposed to financial risks. The decrease in house prices since the economic crisis in 2008 has further increased the risks of over-indebtedness for consumers, as $25 \%$ of home-owners currently have negative equity, thereby hampering mobility on the housing market. Despite high debt and falling prices the percentage of people with mortgage payment arrears is low in the Netherlands ( $1.6 \%$ of all people with a mortgage). A problem with these debt-driven price increases is that they drive up prices and thus reduce accessibility of the market for first-time buyers. A side effect on the rental market of the strong price increases in the 20 years before the economic crisis was a strong incentive for investors to sell rental dwellings, as large indirect yields could be made, thereby leading to a further marginalisation of the private rental sector.

104. The Dutch government has initiated reforms to reduce mortgage-related risks and first steps are taken to reduce fiscal sponsoring of home-ownership. Since 2013 new mortgage loans have to be repaid in 30 years in order to be eligible for tax deductibility. For existing mortgages the rates of deductibility are lowered: from 2014 the maximum rate of 52\% will be reduced to $38 \%$ in gradual steps of 0.5 percentage points per year, and the revenues are used to lower marginal tax rates. The maximum LTV, which is codified in national law, will be lowered from 105 to 100 in 2018 in order to reduce risks of residual debts. The reductions of fiscal benefits and the lowering of LTVs that the Dutch government have initiated are first gradual steps to reduce the risks on the market and to decrease the difference of subsidisation between tenures. These steps can lead to a situation where it will take consumers longer before they can start on the owner-occupied market and thus make the PRS a logical first step on the housing market. 


\section{Box 6.The reduction of mortgage interest deductibility in Finland}

Fiscal sponsoring of home-ownership has been a central feature of the Finnish housing system, and owneroccupied housing remains tax favoured relative to private rental housing, thus making owner-occupied housing the desired tenure for most households. Owner-occupied housing is exempted from capital gains tax and imputed rents are untaxed, although mortgage interests are tax deductible (André and Garcia 2012). The non-taxation of imputed rents is the most important tax subsidy that home-owners receive and constitutes the largest non-neutral component in the tax system with respect to rental housing (see also Country report). Saarimaa (2011) showed that non-taxation of imputed rental income leads to a situation in which most of the subsidy accrues to middle- or high-income households. Important steps to reduce the subsidisation of home-ownership were taken in the 1990s. In the face of the housing bubble and the economic crisis of the early 90s the Finnish government had to scale back government expenditures rapidly. The 1993 tax reform changed the mortgage interest tax deduction rules by changing the deduction rate from a progressive rate to a (much lower) flat rate, effectively reducing the government expenditure for mortgage interest tax deductibility for new mortgages by roughly $50 \%$. The reform lowered the value of the tax deduction for high-income households. As expected, the reform led to lower demand for mortgage debt for high-income households (see Saarimaa, 2010). And in recent years steps have been taken to gradually reduce the importance of the mortgage tax deductibility: before 2011, mortgage interest was fully tax deductible. In 2012, the percentage was reduced to 85 , and then further to 80 in 2013 . The government plans to decrease the percentage to 75 in 2014. Until now these gradual steps to reduce the mortgage tax deductibility have not had large effects on prices on the market. This gradual lowering of the deduction could continue in the coming years, thereby slowly improving tenure neutrality. The decreasing subsidisation of owner-occupied housing improves the position of the PRS on the housing market, as demand is less distorted.

\subsection{The development of an owner-occupied market in the Czech Republic}

105. In the Czech Republic, housing policies are not completely tenure neutral either: fiscal sponsoring of the owner-occupied sector is stronger than support for the rental sector. Total government support for the owner-occupied sector is about three times larger than support for the rental sector. However the stimulation is less strong than in the Netherlands and Finland, and debt levels are at a much lower level. The end effect of the stimulation of home-ownership and the reduction of tenancy security in the rental sector is that home-ownership "became a popular and powerful social norm, while renting, by contrast, became stigmatised as a form of residual and temporary housing." (Lux, country report) In the Czech Republic a mortgage market had to be developed after the Communist era: the change to home-ownership is still a recent phenomenon. In the beginning of the 1990s there were hardly any financing possibilities. The first mortgages were given out in 1995, financed through the introduction of government-covered bonds for housing. Banks were also enabled to issue mortgages in 1995, but a fast increase in mortgage financing could be witnessed only since 2000, as the prices of dwellings started rising, reaching its peak in 2008. In the year after the economic crisis prices declined sharply, now they are stabilising. Home-ownership has risen in the Czech Republic, due to several other developments than fiscal sponsoring of owner occupied housing. Another important reason for an increasing home-ownership rate is low security of tenure in the rental market. Also the owner-occupied market witnessed strong price increases until 2008, and expectations about future price stimulated home-ownership. A last factor is the relatively weak pension system, which makes consumers want to build up capital in their own home. 


\section{Box 7. Saving for your own home: Buildings saving schemes in Germany and the Czech Republic}

An important instrument in both the Czech Republic and Germany are buildings saving schemes, that are used to stimulate saving by consumers to generate capital for the down payment of a mortgage.

Especially on the German housing market building societies ('Bausparkassen') play a very important role. The building saving system is an established means of long-term equity capital formation for house purchase. Savers make regular contractual savings contributions over many years, and when the contract matures they receive the accumulated capital plus interest, and a mortgage loan at a fixed rate. The use of 'Bausparen' is widespread in Germany and the savings contributions are publicly subsidized. Market penetration is very high: $70 \%$ of buyers use the system. Every second German household has at least one contract, representing a total sum of EUR 763 billion or one third of German GDP (Verband der Privaten Bausparkassen 2012, p. 18). The success factors are tight lending requirements for mortgage credit, especially in terms of LTV requirements and the long-term commitment of the government to subsidize this specific type of savings process. German households are used to waiting and saving more money instead of buying a home at an early stage of their life cycle. The average age of first-time buyers, at 40 years, is much higher in Germany than in many other countries.

In the Czech Republic the housing savings scheme was introduced in 1993, comparable with the German or Austrian model of 'Bausparen'. The state supported the savings part of the scheme with a state premium ${ }^{12}$. The idea behind the housing saving scheme is that a consumer saves 40 or $50 \%$ and then get a loan for the rest with the buildings saving institution: the benefit is that households at the start of the saving already get an option for a loan with a fixed interest rate. In reality most people do not save that long, before they buy the house. Often they get a 'bridging loan'; immediately when they start saving, which is interest-only and the interest rate is according to market prices. These bridging loans could have an LTV up to $100 \%$, but after the crisis in 2008 many banks lowered this to $90 \%$. The housing savings scheme became a popular general savings product; and the amount of state support grew from just under CZK 0.3 billion (EUR 11.5 million) in 1993 to CZK 16 billion (EUR 615 million) in 2005 - and then represented more than half of all state housing expenditure. Since 2005 the state expenditures on housing savings scheme have been decreasing but the state premium on housing savings still represents the main public housing subsidy in the Czech Republic. An inefficiency of the system is that it was possible to use the savings scheme also for other purposes than to buy a house.

106. An important measure was to introduce a tax relief for mortgage interest payment in 1995. Home-owners could deduct annually paid mortgage interests (to a limit of CZK 300000 or EUR 11538) from their tax base. In 2014, as a part of government austerity measures the limit will be decreased by more than 70\% to CZK 80000 (EUR 3 077). The importance of mortgage interest deductibility was already substantially lowered by the introduction of a flat tax rate $(15 \%)$ in 2008 , where previously progressive tax rates had been applied with a highest marginal rate of $32 \%$. This is an important step in the direction of more tenure neutrality, which may prevent the problems experienced in Finland in the early 90s and the strong price increases in the Netherlands in the 20 years before the economic crisis of 2008. A further improvement for the Czech case could be to explore the introduction of limits for LTVs, in order to use such an instrument in a countercyclical way on the housing market. In comparison with many western European countries the LTVs are still low. In 2009, the average LTV was 64\%. There are no legal maximums for LTV for mortgages financed by deposits, but there is maximum of 70\% LTV for mortgages financed by mortgage bonds. The Czech National Bank has indicated that it would like to introduce the possibility to set a maximum for LTVs, so that if signs of a bubble appear there are possibilities for intervention. Capital gains are largely untaxed, as there are many exemptions and imputed rents are not taxed in the Czech Republic.

12. The value of the state premium now amounts to $15 \%$ of the annual deposit up to the limit of CZK 2000 (approx. EUR 77), but between 2004 and 2012 was equal to 15\% of the annual deposit up to the limit of CZK 3000 (EUR 115) and between 1993 and 2004 it equalled 25\% of the sum of the annual deposit up to CZK 4500 (EUR 173). 


\subsection{The German housing market shows the benefits of tenure neutrality}

107. On the German housing market owner-occupied housing is not stimulated extensively through fiscal policies, and financial regulations for mortgage lending are prudent. As Kofner concludes: "It is commendable that the German system respects the neutrality of tenures by and large, and prefers owneroccupied housing only to a slight degree, if at all.” (Country report) The subsidies for home-ownership are on a low level in historical comparison. Mortgage interest is not deductible in the German owner-occupied sector because for tax purposes the home is regarded as a consumption good. Hence, no taxation of imputed rent and no deductions of any sort are applied. There is no taxation of capital gains. Also the rules for LTVs are prudent.

108. There was a grant for home-owners, the 'Eigenheimzulage' that was introduced in 1996 and abolished in 2006. It took the place of the tax subsidies for home-ownership that allowed deduction of depreciation and interest on mortgage debt from income tax. The income limits of the Eigenheimzulage were rather generous, but it is not granted since 2006. However, it has continued because of the eight-year eligibility period until 2013. The system of grants was replaced by another instrument that is currently the most important instrument of subsidization: a personal pension scheme known as the "Riester pension". The creation of a voluntary funded pension in the form of financial assets, but also in the form of homeownership ("Wohn-Riester") is promoted with allowances or tax advantages. However the tax advantages are relatively small.

109. The benefits of relative tenure neutrality can be seen from the recent developments on the German housing market: in stark contrast to many other OECD countries the German housing market was not negatively affected by the economic crisis. On the contrary, in fact the prices of owner-occupied housing and rental prices have been rising since 2010, in line with the strong economic performance in Germany. There are however regional differences: prices rising faster in the largest cities and in university cities, while there is oversupply in depopulating areas and in Eastern Germany.

\subsection{Findings: the pitfalls of stimulating home-ownership}

110. The comparison of experiences of the four cases has shown that stimulating home-ownership has its pitfalls: debt levels and prices increase, and thus it is highly questionable whether accessibility of the market actually improves as outsiders have to pay high prices to gain access to the owner-occupied market. The countries with strong sponsoring of home-ownership all witness rising debt levels, growing risks of restrictive equity, and also a pro-cyclical role of house price developments on the wider economy. The PRS market - as an important alternative to owner-occupied housing - can suffer the negative consequences, as demand for owner-occupied housing is stimulated. Also driving up of prices gives incentives to sell (private) rental dwellings, as there are possibilities for indirect yields: this has been an important factor in the reduction of the size of the PRS in the Netherlands. Tenure neutrality, as witnessed in Germany, shows many of the risks that are manifest in the countries that stimulated home-ownership can be prevented. Germany has less price volatility - and more modest price developments, also the tenure choice of households is not distorted. The successive steps to reduce subsidisation of home-ownership in Germany have been successful. Therefore the countries should move towards neutrality of housing policies.

111. The subsidies for home-ownership in Finland are likely to be lowered further, as successive governments have taken steps in this direction. Important steps were already taken after the economic crisis in the early 1990s, and in recent years further reductions have improved the tenure-neutrality of housing policies. The move towards tenure neutrality is much more gradual in the Netherlands: the subsidisation of home-ownership in the Netherlands is very strong to start with, and the reform of mortgage tax deductibility for existing owners is slow. Earlier OECD work has shown these different 
rigidities in the Dutch owner-occupied market and advised to phase out the fiscal subsidisation of homeownership and introduce more tenure neutral policies, as this will improve the functioning of the housing market (OECD 2010, Høj 2011). This will also significantly improve the position of the PRS. A lowering of maximum LTVs in the Netherlands can further reduce the risks on the owner-occupied sector, as currently steps are taken to reduce the LTV to 100. This will lead to more demand for the PRS, as households will have to save longer in order to buy a house. As LTVs impact prices on the housing market strongly it is commendable that the Dutch government uses a gradual approach to lower the LTVs. If further reductions of LTV in the Netherlands are considered, it is worth looking at the housing saving schemes that are in place in Germany and the Czech Republic, so that consumers have a possibility to save for the down payments of mortgages.

112. The Czech Republic witnessed a strong growth of home-ownership, and also used several incentives for home-ownership during the economic transition. The Czech Republic however has the option not to stimulate the owner-occupied sector to the same degree as happened in many other OECD countries.

\section{Supply barriers for the PRS}

113. In this paragraph several specific barriers for the PRS will be discussed, as they can be witnessed in the 4 countries - a full comparison of supply responsiveness, building regulations and zoning and planning in the different countries is outside the scope of this research. As Caldera Sanchez and Johansson showed there are general barriers for housing supply that affect the functioning of the housing market in many OECD countries, and these include geographical circumstances, demographic developments, rigidities in land use or planning policies, problems with competition in the construction sector, and inefficiencies in housing policies for owner-occupied and rental housing (see Caldera Sanchez \& Johansson 2011, pp. 22-25). One of their findings is that housing supply is unresponsive in the Netherlands, and also quite low in Germany. Supply in Finland is in general quite responsive; the Czech Republic was not part of the research (Caldera Sanchez \& Johansson 2011, pp. 14-22, Figure 12). However, their measure is based on the price responsiveness of supply, and thus may be may be distorted by peculiar price developments in some countries: for instance Germany witnessed a steady decline of house prices, whereas the Netherlands witnessed an exceptionally strong growth of house prices. Other indicators of supply responsiveness show a somewhat different picture for the four cases: Germany has the largest housing stock per 1000 inhabitants, followed by Finland, and the Netherlands and the Czech Republic have fewer dwellings (Figure 13). Germany produced the lowest numbers of dwellings per 1000 inhabitants in recent years - possibly reflecting the low population growth, the fact that the housing stock is already quite large and due to the house prices that declined for a long time before 2010. Finland has produced most dwellings per 1000 inhabitants since 2008, and also managed to maintain this high production, despite the economic crisis due to supply subsidisation. In the Netherlands and the Czech Republic there were declines in housing production in recent years, also as a consequence of the relatively strong decrease in house prices in these two countries (Figure 14). 
Figure 12. Price responsiveness of housing supply

Estimates of the long run price-elasticity of new housing supply

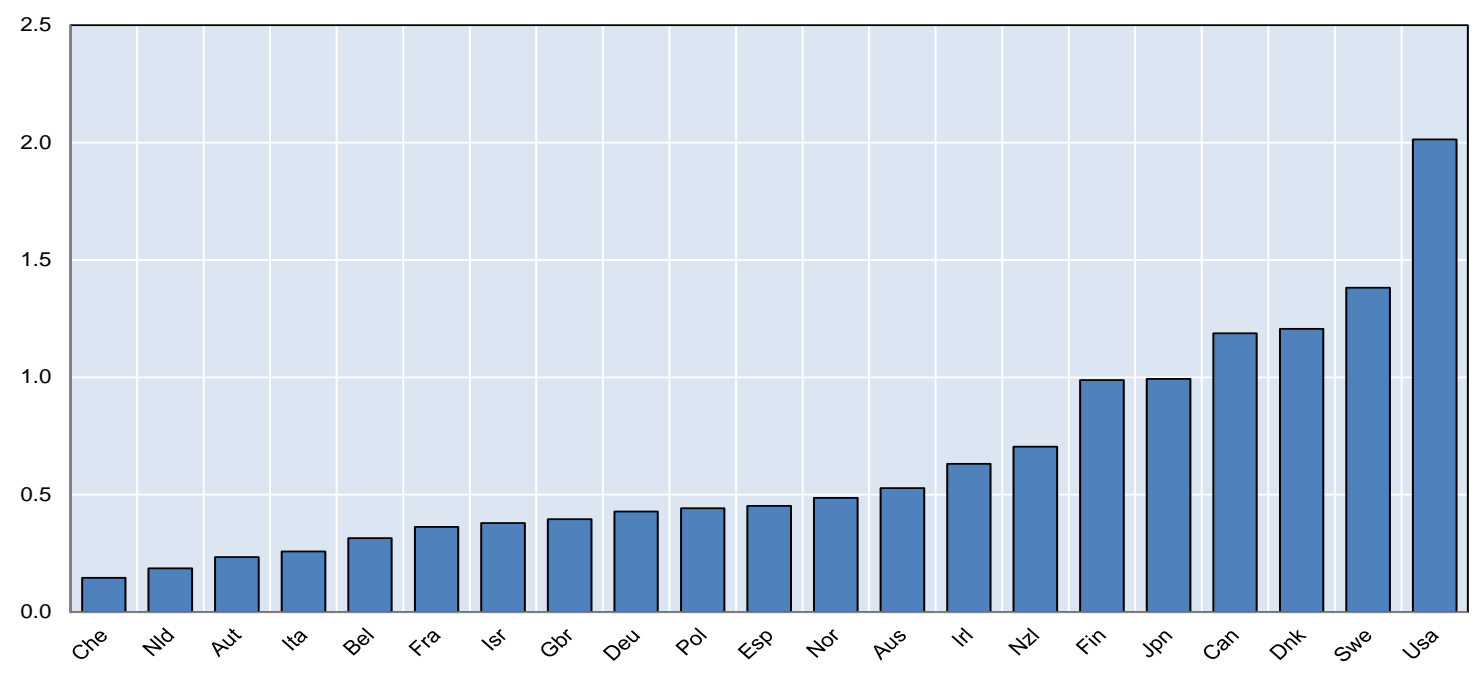

1. Estimates of the long-run price elasticity of new housing supply where new supply is measured by residential investments (i.e. the coefficient on lagged prices in the long-run investment equation as reported in Table 1). All elasticities are significant at least at the $10 \%$ level. The estimation period is from early 1980 s to early/mid 2000s. In the case of Spain, restricting the sample to the period 1995-2007, which would reflect recent developments in housing markets (such as the large stock of unsold houses resulting from the construction boom starting in 2000 and peaking in 2007-09), only slightly increases the estimate of the elasticity of housing supply from 0.45 to 0.58 .

Source: Caldera Sanchez and Johansson 2011

\section{Figure 13. Size of housing stock}

Dwellings per 1,000 inhabitants (2008)

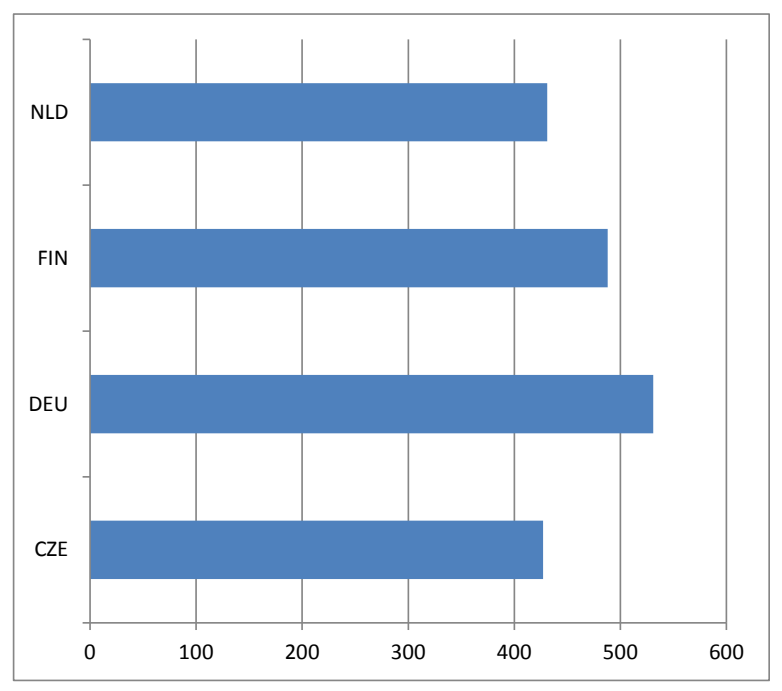

1. CZE: 2001
Figure 14. New supply

\section{Dwellings Completed Per 1,000 People}

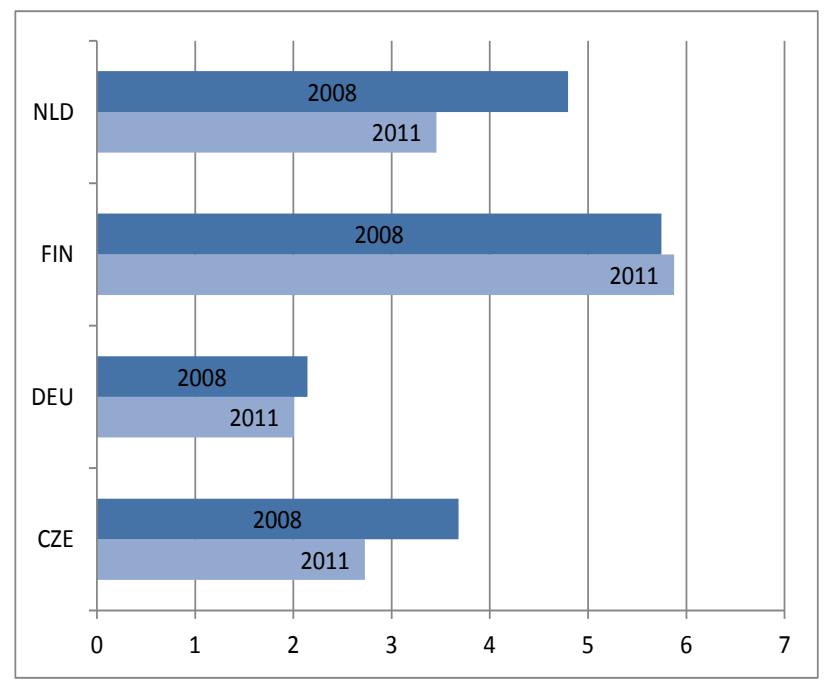

Source: National statistical institutes

Source: UNECE, National statistical institutes 


\subsection{Conversion to PRS dwellings and transaction costs}

114. A first issue are barriers to convert dwellings from the owner-occupied or social housing sector into PRS dwellings. Conversion of existing dwellings is a fast way to increase the supply of the PRS, and if rules for conversion are relaxed, it is a possibility to quickly adapt the housing stock to changing market circumstances. In Germany there are hardly problems with converting social housing, as the social dwelling loses its social status, and thus moves to the PRS or public housing sector at the end of the subsidy period. In the Netherlands there were substantial barriers in place for converting dwellings to the PRS - although recently steps have been taken to reduce these barriers.

115. Given the inefficient allocation of affordable housing in the Netherlands and a relatively large share of owner-occupied housing, conversion of other tenures to PRS can play an important role in enlarging the PRS. In the Netherlands the selling of dwellings of housing associations is regulated. Until now, approval by the minister was needed to sell social dwellings, and about 10000 to 12000 are sold each year -less than $0.5 \%$ of the total social housing stock. The rules have been relaxed from October 2013, as it is now easier to sell complexes of social dwellings of high quality. These dwellings can be sold at $75 \%$ of the value if it would have been vacant - previously this percentage was set at $90 \%$. This high percentage was a disincentive to selling, because these dwellings often still have tenants, and the sale does not break the rental contract.

116. Also for temporarily renting out owner-occupied housing there were rules in the Dutch case: municipal approval is needed to temporarily rent out a dwelling and municipalities calculated a maximum rent for the dwelling. This has now been deregulated in the Vacancy Law, and it is no longer possible for municipalities to make additional rules for temporarily renting out dwellings. The tenancy rules for these temporary rental dwellings were changed; rules for maximum rent setting do not apply, but the minimum duration of the lease should be 6 months, with one month termination for the tenant and 3 months for the landlord. Approval by the bank or mortgage provider is needed, if there is a mortgage on the dwelling.

117. In Finland there are strict regulations on the conversion of social housing: there is a restriction period (mostly 40 years), when it is not allowed to convert the social dwelling to PRS or home-ownership, as the dwellings is subsidised. Due to liberal rent regulations there are no barriers in place for converting owner-occupied housing to PRS (or vice versa); owners of non-subsidised dwellings can rent them out freely without consulting the municipality or other authorities. Given the fact that in large parts of its housing markets are balanced, Finland should give consideration to relaxing the regulations for conversion of social housing. As there are no large price differences between social and private renting in these areas, it could improve the management of the housing stock if landlords had the opportunity to sell social dwellings to tenants or other investors.

118. Transaction taxes - to be paid when a dwelling is sold - can also form a barrier for investments in the PRS and for mobility on the housing market in general. The Netherlands has recently substantially lowered the transaction tax from $6 \%$ of the price to $2 \%$; at this relatively low level it is probably not a large mobility barrier anymore. In Germany the transfer tax has become a state matter and the rates have been increasing over the past years. Before decentralisation the federal tax rate was set at 3.5\%, but in recent years the highest rates charged are 6.5\% in Schleswig-Holstein and 6\% in Berlin, and most states charge $5 \%$. In Finland the transaction tax is set at $4 \%$ for home-owners, but $2 \%$ for housing companies (cooperative housing). First-time buyers under the age of 40 are exempt from paying the transfer tax. In the Czech Republic the transfer tax is $4 \%$. Earlier OECD research recommended lowering of high transaction taxes, and replacing these by increasing taxation on ownership instead of taxing the transaction itself (Boulhol 2011; OECD 2010; André 2010). 


\subsection{Crowding out PRS supply through local targets for social housing}

119. The Finnish and Dutch experiences show that municipalities play a key role in the sponsoring of social housing supply, which can crowd out investments in the PRS. The Finnish experiences show that there can be strong local stimulants to push the social housing sector, which leads to less supply of PRS. As the country report shows in many cities a large share of new development is reserved for social rental housing. For instance, in Helsinki $45 \%$ of all housing is owner-occupied and $45 \%$ is rental housing, and roughly $70 \%$ of the rental housing stock can be characterised as social rental housing. The Municipality of Helsinki sets targets for housing production and tenure division. Although the city has a large social housing stock still $20 \%$ of all new residential construction is municipal social rental housing, and a further $40 \%$ is reserved for student housing and regulated owner-occupied housing called HITAS ${ }^{13}$ (Municipality of Helsinki 2012). As in many other countries, land costs for social housing are lowered by Finnish municipalities: for instance Helsinki lowers the land costs by $40 \%$ for social housing. As the country report concludes these subsidised tenure forms in Finland "directly crowd-out private rental units in places where it would be profitable to build private rental units". An increase of supply in Helsinki could actually help to balance the market better (Box 8).

\section{Box 8. Helsinki faces challenges to increase supply and a complex governance situation}

Most housing markets in Finland are balanced. However there is an insufficient supply of housing for all tenures in the metropolitan region of Helsinki. This is a central concern for all actors involved, as it leads to problems in the housing market and might hamper economic growth. The Finnish Ministry of the Environment indicated that therefore the focus of housing policy is on the metropolitan area. An agreement has been made between the metropolitan region of Helsinki and central government: there is a target of 12000 to 13000 new dwellings per year, of which about 2400 social rental dwellings (20\%). On the whole municipalities have a central role in housing and planning in Finland, as they have a planning monopoly and can steer development through detailed zoning plans, active land policies and direct supply of social housing through municipal housing companies. Especially the position of the City of Helsinki - with its land lease system and its municipal housing company, which is the largest social housing provider in the whole country - is very influential. The central policy element for this is the fact that Helsinki owns $70 \%$ of all land in the city and steers development by setting the terms for 'land leases' to other actors. Helsinki generates an annual income of EUR 200 million through this system of land leases, with lease periods ranging between 50 and 90 years. Despite this central role for the cities and the considerable strength of the instruments that the Municipality has at its disposal, the supply of new housing remains a central problem. Despite the efforts there are not enough residential building plots for market investors, and there is a strict distinction in social and private housing in Finland. Also the Helsinki region has witnessed an oversupply of land for offices and retail, and investors indicate that planning rules can be too detailed.

An important factor that reduces supply responsiveness can be the complex governance situation of the Helsinki Metropolitan Region, as the separate municipalities in the region all have considerable power to limit development. The OECD recently showed that a "lack of inter-municipal co-ordination within a single urban region both for strategy development and service delivery" is an important problem for metropolitan governance in many OECD countries (Kamal-Chaoui \& Sanchez-Reaza 2012, p. 148). National ministries indicate that municipal boundaries may play a role in restricting investment in housing. The strengthening of the regional level of planning in Finland, and stronger incentives by central government to stimulate housing supply could be taken into consideration. A positive development is the recent decision of the Finnish government to address this issue by linking national subsidies for infrastructure to increased efforts by municipalities to improve housing supply in the metropolitan region of Helsinki (Finnish government 2013).

120. Also in the Netherlands municipalities have this role in promoting social housing through strict guidelines and may through additional benefits for social housing crowd out investments in the PRS. Dutch municipalities play an important role in urban planning by working out a 'land exploitation plan', which

13. In Helsinki, there exists a subsidy scheme for owner-occupied housing called HITAS. The subsidy comes through below market level land lot rents. The prices of the dwellings are regulated for a period of 30 years. However, the dwellings can be rented out freely. 
they can do in cooperation with private actors. Within the exploitation plan it is possible to redistribute costs and benefits among the different investors. Often municipalities use a fixed amount for the share of social housing in new housing production - usually set at 20-30\%. Land costs are also reduced for social housing. For owner-occupied and PRS housing the land price differs according to the value of the property that is built. Thus, the municipality can use profits from the selling of land for market sector development (owner-occupied housing, private rental housing) to subsidise social rental housing and owner-occupied housing for low-income households. The higher land prices will most likely be reflected in the dwelling prices applied by developers. Land costs for social housing are lowered through the municipal subsidy, but the magnitude of the benefits related to land costs is hard to assess precisely (Conijn 2011, pp. 27-28; RIGO 2011, pp. 13-14). Municipalities often use fixed discounts for land for social housing, mostly about $30-40 \%$ below the value that is calculated for other residential development.

121. Although this phenomenon of crowding out cannot be completely avoided when supplying social housing, it is questionable whether Finland and the Netherlands - who both have sizeable stock of social housing - actually need such strict targets for social housing production at the municipal level. The negative effects of such targets can also be seen in France, where the central governments has made it mandatory for municipalities to supply at least $20 \%$ of social housing in new housing production (Boulhol 2011). Instead of setting such targets, it is probably better to make more effective use of the existing social stock by creating measures for eligibility and means-testing. Such measures would have more direct effects on the accessibility of people with lower incomes than making further investments in new supply of social housing mandatory.

\section{Conclusions: How to create a level playing field for the PRS?}

122. The PRS can improve the functioning of the housing market - by promoting residential mobility, increasing housing options for households and generating a competitive supply and thus affordable prices. A well-functioning private rental market and a stable housing market can have positive effects on the wider economy and the labour mobility and reduce some of the inefficiencies and risks that are associated with owner-occupied and social housing. The 'resilient' performance of the German housing system during and after the economic crisis has shown that the large PRS and tenure neutral policies have important stabilising effects on the German economy (Kofner 2013). It is therefore essential that governments seek ways of promoting the PRS by reducing and if possible removing unjustified support for the competing owner-occupied and social housing sectors. As Hulse ea. concluded: "The challenge is to develop public policies that see tenures as complementary, while permitting competition between and within tenures, enabling households to meet their housing needs more flexibly as their personal and economic circumstances change.” (Hulse ea. 2010, p. 153)

123. The comparison of experiences of housing policies and reforms in Finland, Germany, the Netherlands and the Czech Republic shows that the PRS can play an important role on the housing market. The comparison also shows that the PRS is affected by policies in many different ways. There are barriers in place for a well-functioning market, and trade-offs exist between different players on the market and between policy goals. It is by no means easy to create a level playing field on the housing market - as there are different kinds of inefficiencies in all four countries. At the same time there are also many positive experiences of stimulating the PRS - reforms in Finland and the Czech Republic in the past years have stimulated the PRS to become a competitive and important part of the housing market, and also Dutch policies are now adapted to stimulate a level playing field on the housing market. In this concluding section the most important barriers and stimulants for a well-functioning PRS are discussed and lessons for future policy are formulated.

124. Tenancy security has a fundamental impact on the rental market and the functioning of the PRS. The German and Dutch cases show that strong tenancy security coupled with efficient eviction 
procedures in case of contract violations can create a stable long-term demand for rental housing, and is in the interest of both tenants and landlords. Strong tenancy security is a necessary condition for creating demand for long-term rental contracts. Unwarranted tenancy protection - in which justified eviction is very troublesome - should be avoided. The Czech Republic witnessed negative consequences of extremely strong tenancy protection and inefficient eviction procedures, as it led to unacceptable risks for investors. Ineffective eviction procedures also negatively affect future tenants by limiting accessibility to the market, as the 'wrong' group of tenants is protected - namely those that do not pay. Czech and Finnish experiences show that substantial weakening of tenancy protection - for instance that selling of a dwelling is a legitimate reason for contract termination as in Finland - leads to a more flexible and temporary demand for rental housing, but reduces the demand for long-term rental contracts. It pushes consumers towards owner-occupancy, making the PRS a more marginal sector, which is seen only as a temporary option.

125. Rent setting regulations require a delicate balance between the interests of tenants and landlords: both 'overregulation' and 'under regulation' of rent setting can lead to a marginal PRS. Rent setting regulations should strike a balance between security for the tenant and flexibility and possibilities for yields for the landlord. Therefore rent setting regulation should occur through a localised system that follows market developments: a good example is the system of local reference rents in Germany. An effective prevention of excessive rent increases and excessive rent demands is advisable, especially in tight markets, because of the asymmetric bargaining power between the landlord and tenants. These requirements come close to be delivered by the current German system, although legal protection for new tenancies could be more effective. The German economic council considers that the current proposals for rent caps for new tenancies can however hamper investment conditions for landlords (Sachverständigenrat 2013). The Czech Republic has recently introduced a system of reference rents and protection against excessive rent increases, similar to the German system.

126. A complete deregulation of rent-setting alters the demand for PRS. The Finnish and Czech experiences show that complete rent deregulation in the PRS, especially when coupled with lowering tenancy security, is a two-edged sword: it leads to a fast increase of PRS supply and thus a better availability of rental dwellings, but the liberal rules undercut demand for long-term private renting. Reduced certainty about future prices and lowered tenancy security undermine long-term demand, as contracts can be changed easily, and dwellings sold easily. Tenants are thus given an incentive to move to the owner-occupied sector, if they want stronger tenure protection. The PRS in both countries became competitive, because of increasing supply, but the PRS at the same time came to be seen mainly as a temporary option for flexible households.

127. Too strong rent regulations lead to problems on the rental market, as the Dutch case shows. There are strong differences between new and existing contracts, lock-in effects in regulated rental housing, reduced accessibility for new households, and long waiting lists for social housing. The experiences in the other three countries suggest that there is scope for the Netherlands to consider setting less tight rent caps on initial and existing contracts, as it hampers investments for landlords and makes the unregulated market residual. It was argued that a more localised system of reference rents, and protection against excessive rent increases could be considered, instead of regulating more than $90 \%$ of the rental market. The aim should be to give sufficient certainty about future rent developments, which would also provide stable framework conditions for investments and improve the availability of rental dwellings.

128. Social housing regulations should ensure an efficient functioning of the social housing sector, and avoid unnecessary distortions of the housing market. A well-targeted social housing sector ensures the accessibility of affordable housing for households that need it most. Targeted social housing does not compete with the PRS and thus does not hinder investments in the private rental market. The German system of social housing does not hinder competition between PRS and social housing, because of the temporary nature of supply subsidies for social housing. However, it requires constant subsidisation to 
keep the social housing stock constant - and this might lead to shortages of social housing in tight markets: better spatial targeting of subsidies is an important challenge for social housing in Germany. Directing them at places where they are most needed would ensure that subsidies are used more efficiently. A reform of this kind may be hard to implement due to the federal structure of the German state, in which the competences are now delegated to the state level. It could be worthwhile to investigate if the federal government should set up a monitoring and benchmark system for social housing need and supply, in order to stimulate investments where they are most needed.

129. In the Netherlands, social housing dominates the rental market: the legal and financial position of associations is so strong that the PRS cannot compete. It will be essential for the future prospects of the private rental market in the Netherlands to focus social landlords on their core tasks - providing affordable housing. Clear legal boundaries between social investments of housing associations and commercial activities are a necessary condition for a level playing field. A step in this direction could result from stricter targeting the regulated part of the market, as currently $93 \%$ of the rental market is regulated (all rents below EUR 681) while most inhabitants of the regulated sector cannot afford rents above EUR 600. It could be beneficial to decrease the regulated sector of the market, by lowering the maximum regulated rent to the maximum level for the housing allowance (EUR 574) (see also Høj 2011). This could stimulate commercial investments in the segment above this boundary, which in turn would lead to improved accessibility of middle-income households to the private rental market.

130. Effective governance and oversight of social housing should be ensured. The negative consequences of lacking regulation of social housing can be witnessed in the Czech Republic: The current lack of clear goals or oversight, and the common practice of selling public housing below the market value raise efficiency concerns. Finland also witnessed problems with the municipal oversight over social housing, which is now proposed to be centralised by the Ministry of the Environment. Further gains could be made by streamlining and clarifying the rules for the social housing sector.

131. The definition of a clear target group for social housing can improve the efficiency of social housing. The introduction of an eligibility criterion in the Netherlands led to better accessibility of social housing for people with lower incomes. Given the relatively large stock of social housing in both Finland and the Netherlands, strong segregation effects are not to be expected from introducing measures to target the social housing sector better, and it could actually increase accessibility for households with the lowest incomes by increasing turnover rates. The Czech Republic currently completely lacks the definition of a target group for social housing, and could therefore consider the introduction of a target group for vacated public dwellings in order to increase the efficiency of the use of the municipal public housing stock.

132. In tax treatment for the rental sector it is advisable to aim for neutrality. The case studies show that it is hard to strike a balance between the different tenures on the housing market and between stimulation and fiscal concerns. Tax measures can have stimulating effects, as can be seen in the German case. The large rental sector in Germany was built up by generous tax benefits, such as decreasing depreciation and tax benefits to stimulate maintenance of rental dwellings, thereby keeping the quality of rental housing high. However it has proven hard to target such tax incentives effectively to the places where investments are needed. Tax treatment can have negative effects for the development of the PRS as well; for instance the recent introduction of a tax on rental dwellings for landlords in the Netherlands is a considerable disincentive for investment in rental dwellings, especially for PRS landlords that do not receive state guarantees and subsidies. Priemus (2014) therefore proposes to abolish the measure as soon as the budgetary situation of the Dutch government improves. A reduction of the tax could be financed by levying higher property taxes on all forms of residential ownership, which would have less distortive effects on the housing market (Priemus 2014). 
133. Housing allowances can reduce the differences between subsidisation of different tenures and can be an effective way of enabling accessible and affordable housing for people with lower incomes. All countries in our sample except the Netherlands have moved to a tenure neutral housing allowance. The broad-based systems of demand subsidies that are in place in all 4 countries are playing a very important role on the housing market in keeping housing affordable, while at the same time guaranteeing for landlords that people with lower incomes are able to pay the rent. Housing allowances in the Netherlands and Finland do not foresee strong regional differentiation. The allowance system could be improved, for instance through coupling the allowance to local reference rents. A problem with housing allowances is that they can become capitalised into housing prices: in both tight markets and in more balanced housing markets prices are pushed up by allowances that are based on actual rents. This occurs especially if housing supply is restricted (André 2010).

134. Neutrality of housing policies can be improved, especially by reducing the fiscal sponsoring of home-ownership. Strong support for home-ownership can lead to risks for banks, consumers and governments, and can have a pro-cyclical effect on the economy ${ }^{14}$. The comparison of experiences of the four cases has shown that stimulating home-ownership has its pitfalls: countries with strong stimulation show rising debt levels, and strong price increases during upswings, risks for negative equity, and also a pro-cyclical role of house price developments on the wider economy. It is highly questionable whether accessibility of the market actually improves as outsiders have to pay high prices to gain access to the owner-occupied market. The PRS market - as important 'market alternative' to owner-occupied housing suffers the negative consequences, as demand for owner-occupied housing is stimulated. The German case suggests that tenure neutrality can prevent many of the risks that are manifest in countries that stimulated home-ownership: Germany has less price volatility - and more modest price developments, and also the tenure choice of households is not distorted. The steps taken by Germany to reduce subsidisation of homeownership have been successful. Finland has started moving in the same direction, even though homeownership is still tax favoured. Important steps were already taken after the economic crisis in the early 1990s, and in recent years further reductions have improved the tenure-neutrality of the housing policies. The move towards tenure neutrality is more gradual in the Netherlands - and earlier OECD research recommended phasing out the mortgage interest deductibility (OECD 2010). Tenure neutrality could improve the position of the PRS significantly.

135. Also loan-to-value ratios for mortgage loans can play an important role on the housing market and affect demand. In general there is a trade-off between financial risks and access to mortgage credit. Some countries use maximum norms for LTVs as part of macro prudential strategies, to prevent procyclical developments on the housing market and to safeguard financial stability. Besides setting LTVs countries have other possibilities to reduce these risks, for instance through mortgage insurance schemes and state guarantees on mortgages. Mortgage-covered bonds reduce funding risks. In the Netherlands the LTVs were becoming high - well above 100 - during the upswing on the housing market, and therefore gradual lowering of maximum LTVs in the Netherlands was introduced, in order to reduce risks in the owner-occupied sector. This will lead to more demand for the PRS, as households will have to save longer in order to buy a house. Possible further reductions of LTVs in the Netherlands could be coupled with introducing a housing saving scheme, comparable to those in Germany and the Czech Republic. This gives consumers the possibility to save for the down payments of mortgages. The Czech Republic - which currently still has low LTVs in international comparison - could also consider introducing the possibility to use a maximum for LTVs as a precautionary measure.

136. The Czech Republic witnessed a strong growth of home-ownership, and also used several incentives for home-ownership during the economic transition. It is commendable that the Czech

14. See for instance Brixiova ea 2009 on the loan financed boom/bust cycle in Estonia. 
government is already reducing subsidies for home-ownership, for instance by significantly lowering mortgage interest tax deductibility: this is an important step towards tenure neutrality. Taking these steps now may help prevent the problems that were witnessed in Finland in the early 90s and the Netherlands after the economic crisis of 2008. A further improvement for the Czech housing policy is a better targeting of the housing savings scheme, by making the system less profitable for higher incomes and by limiting it to housing purposes only.

137. Several barriers for PRS supply could be reconsidered. Conversion of tenures - to transfer dwellings from the owner-occupied sector or social housing to PRS dwellings - is a way to quickly increase supply in the PRS. Barriers for conversion should be removed unless there are strong reasons not do so. In the Netherlands recently steps were taken to increase possibilities of selling high-quality social dwellings, and also to improve temporary conversion of owner-occupied housing. Scope for the conversion of social housing also seems to exist in Finland, especially as housing markets are balanced in most regions. Also a reduction of transaction taxes can contribute to supply for the PRS, and improve residential mobility in general. Such measures could be financed by increasing recurrent taxes on property.

138. Municipal targets for social housing can crowd out investments and supply in the PRS, as can be seen in the Helsinki region in Finland and the Netherlands. Both countries have a sizeable stock of social housing and it is worth reconsidering if targets for social housing production at the municipal level are needed. It is probably better to make more effective use of the existing social stock by creating measures for eligibility and means-testing. Such measures will have more direct positive effects on the accessibility of people with lower incomes, rather than making further investments in new supply of social housing mandatory through local planning instruments, like zoning. 


\section{BIBLIOGRAPHY}

André, C. (2010), “A Bird's Eye View of OECD Housing Markets.” OECD Economics Department Working Papers, No. 746, OECD Publishing. http://dx.doi.org/10.1787/5kmlh5qvz1s4-en.

André, C. and C. García (2012), "Housing Price and Investment Dynamics in Finland”, OECD Economics Department Working Papers, No. 962.

Andrews, D., A. Caldera Sánchez and Å. Johansson (2011), "Housing Markets and Structural Policies in OECD Countries”, OECD Economics Department Working Papers, No. 836.

Blanchflower, D. G. and A. J. Oswald (2013), “Does High Home-Ownership Impair the Labour Market?”, Working Paper Series, WP13-3, Peterson Institute for International Economics.

Boulhol, H. (2011), "Making the French Housing Market Work Better”, OECD Economics Department Working Papers, No. 861, OECD Publishing, http://dx.doi.org/10.1787/5kgcd9w73qvf-en.

Brixiova, Z., L. Vartia and A. Wörgötter (2010), “Capital Flows and the Boom-bust Cycle: The Case of Estonia,” in Economic Systems, Elsevier, Vol. 34(1), pp. 55-72, March.

Caldera Sánchez, A. and Å. Johansson (2011), “The Price Responsiveness of Housing Supply in OECD Countries”, OECD Economics Department Working Papers, No. 837, OECD Publishing. http://dx.doi.org/10.1787/5kgk9qhrnn33-e.

City of Amsterdam Development Corporation (2005), The Use of Public Ground Lease in European Cities.

Conijn, J. (2011), De Vastgoedlezing 2011: 'Woningcorporaties op een kruispunt: Wat zijn de gevolgen van een nieuw evenwicht tussen staatssteun en 'level playing field'? Amsterdam School of Real Estate, Amsterdam.

CPB (2010), Hervorming van het Nederlandse woonbeleid, CPB paper, No. 84, April 2010.

Djankov, S., R. La Porta, F. Lopez de Silanes and A. Shleifer (2003), “Courts: The Lex Mundi Project”, in The Quarterly Journal of Economics, Vol. 118, No. 2, May 2003.

European Commission (2014), Housing and Mortgage Markets Institutional Features and Regulation in the EU. EC: Brussels.

Finnish government (2013), Government Decision on Implementing the Structural Policy Programme, 2911-2013.

Fitzpatrick, S. and H. Pawson (2013), "Ending Security of Tenure for Social Renters: Transitioning to ‘Ambulance Service’ Social Housing?”, in Housing Studies (2013), DOI: 10.1080/02673037.2013.803043

Griggs, J. and P. A. Kemp (2012), "Housing Allowances as Income Support: Comparing European Welfare Regimes”. International Journal of Housing Policy, Vol. 12:4, pp. 391-412, DOI: 10.1080/14616718.2012.711987 
Haffner, M., J. Hoekstra, M. Oxley and H. van der Heijden (2009), Bridging the Gap between Social and Market Rented Housing in Six European Countries, IOS Press, Amsterdam.

Hirsch, W. Z (2000), “Renting”, in B. Boudewijn and G. De Geest (2000), Encyclopedia of Law and Economics, Cheltenham, UK: Edward Elgar.

Høj, J. (2011), “Improving the Flexibility of the Dutch Housing Market to Enhance Labour Mobility”, OECD Economics Department Working Papers, No. 833, OECD Publishing. http://dx.doi.org/10.1787/5kgkdgfkxrr2-en.

Hulse, K., C. Jones and H. Pawson (2010), “Tenurial 'Competition', Tenure Dynamics and the Private Rented Sector: An international reappraisal”, in Journal of European Real Estate Research, Vol. 3 No. 2, pp. $138-156$.

Hulse, K., and V. Milligan (2014), "Secure Occupancy: A New Framework for Analysing Security in Rental Housing, Housing Studies”, DOI: 10.1080/02673037.2013.873116

Kemeny, J., J. Kersloot and P. Thalmann (2005), “Non-profit Housing Influencing, Leading and Dominating the Unitary Rental Market: Three Case Studies”, in Housing Studies, Vol. 20, No. 6, 855-872, November 2005.

Koalitionsvertrag (2013), Koalitionsvertrag zwischen CDU, CSU und SPD: Deutschlands Zukunft gestalten.

Kofner, S. (2003), Die Formation der deutschen Wohnungspolitik nach dem Zweiten Weltkrieg, Teil I-III, in Deutsche Wohnungswirtschaft, Vol. 55, Iss. 10-12.

Kofner, S. (2013), “The German Housing System: Fundamentally Resilient”? in Journal of Housing and the Built Environment, DOI 10.1007/s10901-013-9383-0.

KTI (2013), The Finnish Property Market 2013, KTI, Helsinki.

Laamanen, J-Petri (2013), "Home-ownership and the Labour Market: Evidence from Rental Housing Market Deregulation”. Working Paper, No. 89. Tampere Economic Working Papers Net Series.

Leuvensteijn, M. van and P. Koning (2000), The Effects of Home-ownership on Labour Mobility in The Netherlands: Oswald's theses revisited, CPB, The Hague.

Lind, H. (2001), "Rent Regulation: A Conceptual and Comparative Analysis”, in International Journal of Housing Policy, Vol. 1, No. 1, pp. 41-57.

Loikkanen, H. A. and H. Lönnqvist (2007), “Metropolitan Housing Markets - The Case of Helsinki”, in A. E., Andersson, L. Petterson, U. Strömqvist (eds.) (2007), European Metropolitan Housing Markets. Springer Verlag: Berlin.

Lux, M. and P. Sunega (2010), "Private Rental Housing in the Czech Republic: Growth and...”? in, Sociologický ćasopis/Czech Sociological Review, 2010, Vol. 46, No. 3, pp. 349-373.

Lux, M. and P. Sunega (2013), "New Social Housing Strategies in Post-socialist States: Effectiveness, Efficiency, and Sustainability”, pp. 307-330, in J., Hegedüs, M. Lux, N. Teller (eds.), Social Housing in Transition Countries, Routledge, New York, London. 
Lux, M. and P. Sunega (2014), Public Housing in the Post-Socialist States of Central and Eastern Europe: Decline and an Open Future. Housing Studies, DOI: 10.1080/02673037.2013.875986

Lyytikäinen, T. (2006), "Rent Control and Tenants' Welfare: The Effects of Deregulating Rental Markets in Finland”, VATT Discussion Papers, No. 385, Helsinki: Government Institute.

Municipality of Helsinki (2012), Home Town Helsinki: The Goals and Objectives of Housing and Land use Planning.

OECD (2010), OECD Economic Surveys: Netherlands, June 2010. OECD Publishing.

OECD (2013), “Modern families”, in Trends Shaping Education 2013, OECD Publishing. http://dx.doi.org/10.1787/trends_edu-2013-7-en

O’Sullivan, E. and P. De Decker (2007), “Regulating the Private Rental Housing Market in Europe”, in European Journal of Homelessness, Vol. 1, December 2007, pp. 95-117.

Oxley, M., M. Elsinga, M. Haffner and H. Van der Heijden (2010), "Competition and Social Rented Housing”, in Housing, Theory and Society, Vol. 27:4, pp. 332-350, DOI: 10.1080/14036090903326395.

Priemus, H. (2014), "Is the Landlord Levy a Threat to the Rented Housing Sector? The Case of the Netherlands", in International Journal of Housing Policy, DOI: 10.1080/14616718.2013.876579.

Saarimaa, T. (2010), “Tax Incentives and Demand for Mortgage Debt: Evidence from the Finnish 1993 Tax Reform”, in International Journal of Housing Policy Vol. 10(1), pp. 19-40.

Saarimaa, T. (2011), “Imputed Rental Income, Taxation and Income Distribution in Finland”, in Urban Studies, Vol. 48(8), pp. 1695-1714.

Sachverständigenrat zur Begutachtung der gesamtwirtschaftlichen Entwicklung (2013), Gegen eine rückwärtsgewandte Wirtschaftspolitik Jahresgutachten 2013/14. Statistisches Bundesamt: Wiesbaden.

Scanlon, K. and B. Kochan (2011), Towards a sustainable private rented sector: The lessons from other countries, LSE, London.

Scanlon, K. and M. Elsinga (2013), "Policy changes affecting housing and mortgage markets: how governments in the UK and the Netherlands responded to the GFC", in Journal of Housing and the Built Environment, DOI 10.1007/s10901-013-9390-1.

Stephens, M. and C. Whitehead (2013), "Rental Housing Policy in England: Post Crisis Adjustment or Long Term Trend"? in Journal of Housing and the Built Environment, DOI 10.1007/s10901-0139386-x

Turner, B. and M. Elsinga (2005), "Housing Allowances: Finding a Balance Between Social Justice and Market Incentives”, European Journal of Housing Policy, Vol. 5 (2), pp. 103-109.

UIPI (Union Internationale de la Propriété Immoblière) (2013), Landlords in Europe: A Comparative Analysis, UIPI: Brussels. 
University of Cambridge (2012), The Private Rented Sector in the New Century - a Comparative Approach. Boligøkonomisk Videncenter, Copenhagen.

Vandevyvere, W. and A. Zenthöfer (2012), “The Housing Market in the Netherlands”. Economic Papers No. 457. European Commission, Brussels.

Vartia, L. (2006), “Finland's Housing Market: Reducing Risks and Improving Policies”, OECD Economics Department Working Papers, No. 514. http://dx.doi.org/10.1787/045113767231

Verband der Privaten Bausparkassen (2012), Bausparen in Deutschland.

Voigtländer, M. (2013), “The Stability of the German Housing Market”, in Journal of Housing and the Built Environment, DOI 10.1007/s10901-013-9366-1.

WSW (Waarborgfonds Sociale Woningbouw) (2013), Hoeder van de borg: Jaarverslag 2012. Hilversum. Country reports, No 15.

De Boer, F.W. (2013), The Dutch Housing Market: The Position of the Private Rental Sector.

Eerola, E., T. Lyytikäinen and T. Saarimaa (2013), The Position of the Private Rental Sector in Finland.

Kofner, S. (2013), The Private Rental Sector in Germany.

Lux, M. (2013), History and Recent Status of Private Renting in the Czech Republic. 
ECO/WKP(2014)66

\section{WORKING PAPERS}

The full series of Economics Department Working Papers can be consulted at www.oecd.org/eco/workingpapers

1169 Secular stagnation: evidence and implications for economic policy

(October 2014) by Łukasz Rawdanowicz, Romain Bouis, Kei-Ichiro Inaba and

Ane Kathrine Christensen

1168. Investment gaps after the crisis

(October 2014) by Christine Lewis, Nigel Pain, Jan Strasky and Fusako Menkyna

1167. Factors behind the decline in real long-term government bond yield

(October 2014) by Romain Bouis, Kei-Ichiro Inaba, Łukasz Rawdanowicz and

Ane Kathrine Christensen

1166. The effect of the global financial crisis on the OECD potential output

(October 2014) by Patrice Ollivaud and David Turner

1165. Determinants of households' investment in energy efficiency and renewables - evidence from the OECD Survey on household environmental behaviour and attitudes

(October 2014) by Nadia Ameli and Nicola Brandt

1164. Addressing high household debt in Korea

(September 2014) by Randall S. Jones and Myungkyoo Kim

1163. Reducing the high rate of poverty among the elderly in Korea

(September 2014) by Randall S. Jones and Satoshi Urasawa

1162. Promoting the financing of SMEs and start-ups in Korea

(September 2014) by Randall S. Jones and Myungkyoo Kim

1161. Fostering inclusive growth by promoting structural change in the business sector

(September 2014) by Rauf Gönenç, Oliver Röhn, Vincent Koen and Fethi Öğünç

1160. Reducing macroeconomic imbalances in Turkey

(September 2014) by Oliver Röhn, Rauf Gönenç, Vincent Koen and Evren Erdoğan Coşar

1159. Reinvigorating the EU Single Market

(September 2014) by Jean-Marc Fournier.

1158. An exploration of the determinants of the subjective well-being of Americans during the great recession

(August 2014) by Aida Caldera Sánchez and Caroline Tassot.

1157. Boosting the development of efficient SMEs in the Netherlands

(September) by Rafał Kierzenkowski and Jochebed Kastaneer

1156. Making the banking sector more resilient and reducing household debt in the Netherlands (September 2014) by Rafał Kierzenkowski, Olena Havrylchyk and Pierre Beynet 
1155. US long term interest rates and capital flows to emerging economies

(July 2014) by Eduardo Olaberria

1154. Productivity measurement with natural capital and bad outputs

(July 2014) by Nicola Brandt, Paul Schreyer and Vera Zipperer

1153. Reducing income inequality and poverty and promoting social mobility in Korea (July 2014) by Randall S. Jones and Satoshi Urasawa

1152. Fostering a creative economy to drive Korean growth

(July 2014) by Randall S. Jones and Myungkyoo Kim

1151. Economic uncertainties and their impact on activity in Greece compared with Ireland and Portugal

(July 2014) by Jan-David Schneider and Claude Giorno

1150. Workplace stress in the United States: issues and policies

(July 2014) by Michael Darden

1149. Taxing the rent of non-renewable resource sectors: a theoretical note

(July 2014) by Julien Daubanes and Saraly Andrade de Sá

1148. Health, work and working conditions: a review of the European economic literature

(July 2014) by Thomas Barnay

1147. Making the best of new energy resources in the United States

(July 2014) by Douglas Sutherland

1146. Improving well-being in the United States

(July 2014) by Aida Caldera Sánchez, Patrick Lenain and Sarah Fléche

1145. Deconstructing Canada's housing markets: finance, affordability and urban sprawl

(July 2014) by Calista Cheung

Restructurer les marchés canadiens du logement: financements, accessibilité financière et étalement urbain

(Juillet 2014) par Calista Cheung

1144. Women's role in the Swiss economy

(July 2014) by Richard Dutu

Le rôle des femmes dans l'économie suisse

(Juillet 2014) par Richard Dutu

1143. Overcoming skills shortages in Canada

(July 2014) by David Carey

Combler les pénuries de compétences au Canada

(Juillet 2014) par David Carey

1142. Trade patterns in the 2060 world economy

(July 2014) by Jean Chateau, Lionel Fontagné, Jean Fouré, Åsa Johansson and Eduardo Olaberria 